\title{
Measuring the Effectiveness of Foot Patrol in the Downtown Yonge BIA
}

\author{
By \\ Jeffrey Reilly \\ A thesis submitted to the Faculty of Graduate and Post Doctoral Affairs in partial \\ fulfillment of the requirements for the degree of \\ Master of Arts \\ in \\ Legal Studies
}

Carleton University

Ottawa, Ontario

(C) 2011

Jeffrey Reilly 
Library and Archives

Canada

Published Heritage

Branch

395 Wellington Street

Ottawa ON K1A ON4

Canada
Bibliothèque et

Archives Canada

Direction du

Patrimoine de l'édition

395 , rue Wellington

Ottawa ON K1A ON4

Canada
Your file Votre référence

ISBN: 978-0-494-87788-3

Our file Notre référence

ISBN: $978-0-494-87788-3$

\section{NOTICE:}

The author has granted a nonexclusive license allowing Library and Archives Canada to reproduce, publish, archive, preserve, conserve, communicate to the public by telecommunication or on the Internet, loan, distrbute and sell theses worldwide, for commercial or noncommercial purposes, in microform, paper, electronic and/or any other formats.

The author retains copyright ownership and moral rights in this thesis. Neither the thesis nor substantial extracts from it may be printed or otherwise reproduced without the author's permission.
AVIS:

L'auteur a accordé une licence non exclusive permettant à la Bibliothèque et Archives Canada de reproduire, publier, archiver, sauvegarder, conserver, transmettre au public par télécommunication ou par l'Internet, prêter, distribuer et vendre des thèses partout dans le monde, à des fins commerciales ou autres, sur support microforme, papier, électronique et/ou autres formats.

L'auteur conserve la propriété du droit d'auteur et des droits moraux qui protege cette thèse. $\mathrm{Ni}$ la thèse ni des extraits substantiels de celle-ci ne doivent être imprimés ou autrement reproduits sans son autorisation.
In compliance with the Canadian Privacy Act some supporting forms may have been removed from this thesis.

While these forms may be included in the document page count, their removal does not represent any loss of content from the thesis.
Conformément à la loi canadienne sur la protection de la vie privée, quelques formulaires secondaires ont été enlevés de cette thèse.

Bien que ces formulaires aient inclus dans la pagination, il n'y aura aucun contenu manquant. 


\begin{abstract}
$\underline{\text { Abstract }}$
The issues of fear and insecurity in business improvement areas has given rise to commodified policing patrols aimed at targeting "undesirables" and reducing "urban decay". This thesis studied the merchant response to police patrols in order to assess the effectiveness of the police patrols in reducing incidents of urban decay and the overall levels of crime. Furthermore, this thesis sought to find an empirical relationship between broken windows style policing and the reduction of the levels of fear associated with particular incidents of crime. A Merchant Security Satisfaction Survey was used to ask a series of questions related to fear, risk, policing, and undesirables (i.e. homeless, youth gangs, panhandlers). The data showed that according to merchant perception, police presence and foot patrols positively affected crime levels by reducing sources of fear and crime. This thesis concludes that the partnership between public and private organizations positively affected the levels of crime.
\end{abstract}




\section{Acknowledgements}

I would like to thank all those who facilitated my research including Carleton University, the Downtown Yonge Business Improvement Area, the merchants of the Downtown Yonge Business Improvement Area for the time they took to answer the surveys and all of my questions. I would also like to thank all the people who supported me and pushed me through the entire process; Tim Reilly, Terry Williams, Jane Flett, Robert Post, Susan Son, Vivian Chiu, Melissa Conte, Nicole Sammut, and Gisell Castillo. I would especially like to thank Dr. George Rigakos for all of his time, patience, and guidance as well as Dr. Jane Dickson-Gilmore, Dr. Craig Bennell, Betina Kuzmarov for participating in my thesis defense panel. 
Chapter 1 - Introduction

Chapter 2 - Risk, Commerce, and Business Improvement $\quad$ -

Chapter 3 - Initial Analysis $\quad$ - 39

Chapter 4 - Comprehensive Analysis $\quad$ -

Chapter 5 - In-depth Discussion $\quad$-.--one 81

Chapter 6 - Conclusion

Bibliography - -.-.-- Page 99 


\section{List of Tables}

Table $3.1 \quad-1-10$

Table $3.2 \quad-2$

Table $3.3 \quad-34$

Table 3.4 -

Table $3.5 \quad-1-10$

Table 3.6 - -

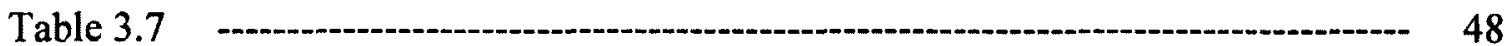

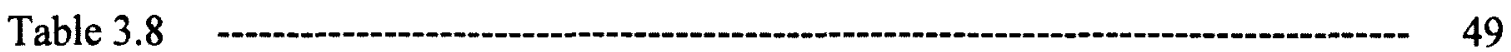

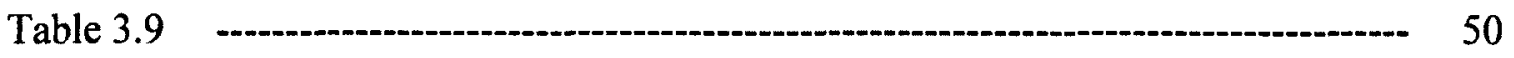

Table $3.10 \quad-10$

Table $3.11 \quad-$

Table $3.12 \quad-12$

Table $3.13 \quad--13$

Table $3.14 \quad-14$

Table 3.15 - -

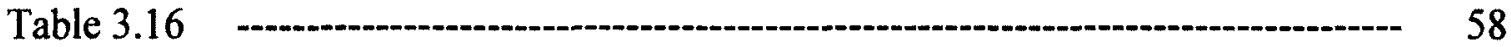

Table $3.17 \quad--17$

Table $3.18 \quad-18$

Table $4.1 \quad-1$

Table $4.2 \quad-2$

Table $4.3 \quad-36$

Table $4.4 \quad-108$

Table $4.5 \quad-31$ 
Table 4.6 -

Table $4.7 \quad$-...- 75

Table 4.8 - -

Table $4.9 \quad-1 .-17$

Table $4.10 \quad-10$

Table 4.11 - -

Table $4.12 \quad-12$

Table $4.13 \quad-13$

Table $4.14 \quad--14$

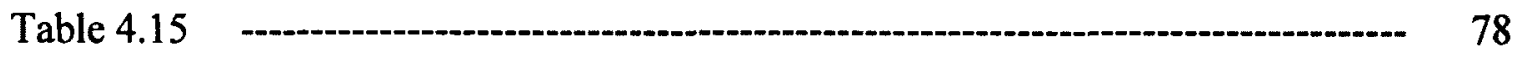

Table $4.16 \quad-16$

Table 4.17 - - 


\section{List of Appendices}

Appendix A

Appendix B

Page 110

Appendix C

Page 112 


\section{Chapter 1: Introduction}

Safety and security has been the central focus of Business Improvement Areas in urban centres. Specifically, Business Improvement Areas in urban centres such as Toronto have actively sought measures and controls that would effectively address the levels of crime, fear, and risk within their area of influence. The Downtown Yonge Business Improvement Area (DYBIA) has used police foot patrol, environmental design, and merchant participation in order to address crime, fear, and risk. This thesis continues upon the work studying the residual influence of the foot patrol program started in $2005^{1}$ by utilizing a Merchant Security Satisfaction Survey (MSSS) and close observation of the area being studied. The patrols carried out by the Toronto Foot Patrol Program were intended to reduce the crime in the aforementioned area by creating a greater level of visibility and enforcement of social and economic standards. The enforcement of social and economic standards involved removing individuals who did not meet the desired level of socio-economic status from the area as "undesirables" (i.e. homeless, youth gangs, etc). This policing style was considerably different than the currently employed method of policing agencies which rely upon reactive and responsive policing; whereby the policing agency is dispatched to incidents instead of actively seeking incidents. The foot patrol program that was utilized in the DYBIA was a proactive approach through which the police officers would patrol the area at regular intervals and identify possible sources of crime through department risk assessment and respond accordingly.

\footnotetext{
${ }^{1}$ See Gavendo, M. J. (2006). Toronto Public Policing For Hire: The Effects of Commodification of Policing Services in the Downtown Yonge Business Improvement Area. Carleton University, Ottawa.
} 
This method of policing was also coupled with an environmental design policy that promoted safety and security in the area. Some of the measures used in an environmental design policy include strategic lighting, benches, trees, frequent garbage bins and recycling spots, and many other options. The purpose of these measures is to provide friendly, clean, and open environments which invite people to frequent by minimizing the negative effects that may inevitably gather in urban centres.

Finally, merchant participation was used by the DYBIA in order to further enhance foot patrols and environmental design by encouraging the reporting of issues that require attention before those issues become sources of crime. Examples include drug dealers, the homeless and panhandlers, graffiti, garbage, etc. As the merchants report the issues and they are dealt with by either police foot patrols or DYBIA cleaning crews, the incidence occurrences and crime levels are minimized.

For the purpose of this thesis, I will focus upon the merchant response to these three factors (police effectiveness, DYBIA effectiveness, and merchant cooperation) with respect to fear, risk, and crime. As this paper is a continuation of a previous academic work on the effectiveness of foot patrol ${ }^{2}$, it can be used as a measurable basis of comparison for data analysis on the use of privatized policing and security.

The use of police in privatized roles has increased as the demand for safety and security has risen, particularly in urban centres. In 2005 , the use of police as an effective security force was implemented by the Downtown Yonge Business Improvement Area for the purpose of addressing the decline and build up of undesirables in the area through social control measures and active governance. The DYBIA contacted the Toronto Police Service to investigate a switch in policing services that would reflect the desires of 
the DYBIA and focus on the issues that they determined, as opposed to the traditional method of policing whereby police determined their own issues and policed in the manner they saw fit. As Gavendo wrote:

"The commodification of public policing includes the process by which security strategies - more traditionally characteristic of private security providers - are now being undertaken by public police. Commodified public policing includes, but is not limited to, deployment practices prioritizing risk-based models, harm minimization, prevention and deterrence" (Gavendo, 2006: 4-5).

This use of commodified policing was in place for two years until 2007 when control of the program was given to precincts themselves and continued in a public capacity. In 2009 , the program continued to be controlled by the Toronto Police Service in a capacity that takes advantage of the ongoing partnership between public and private. More specifically, the BIA continued to work alongside the Toronto Police without actually paying the police for their services. The idea of the Toronto Police "selling" their services has been replaced by an initiative whereby the issues that merchants and DYBIA recognize can be reported and looked into by the specialized task force called "The Downtown Yonge Community Foot Patrol". This task force operates with the cooperation of DYBIA and the merchants in the area because the required coverage and monitoring resources cannot be achieved by just one party. The effectiveness of this program is dependent upon the participation of all three parties. The merchants look out for the undesirables in proximity to their business and similar interests in the area. DYBIA looks after the cleanliness of the area and environmental design that aid police and merchants in the beautification of the area as well as protection and risk 
management. The foot patrol then focus on loss prevention, ubiquitous surveillance, policing individuals that were labelled as "undesirable", and order maintenance. The three groups work collectively to create a partnership that reduces and minimizes risk, fear, and crime in the downtown Yonge area. The theoretical framework and data supporting this discussion will be examined in further chapters.

\section{Review of Concepts:}

The growth and proliferation of mass privatized public space has created a demand for increased safety and security which is beyond the scope and resources of public policing services. As a result, private policing corporations are necessary to fill the void left by public policing organizations. However, the demand for further policing power increased with the growth of private policing organizations in order to maintain the clear divide between public and private policing (Shearing \& Stenning, 1981). As the demand increased, the necessity of hiring police officers to perform security roles rose accordingly. The police were hired to perform security roles on their off hours and were paid for special duties or "paid duties". These paid duties officers performed all of the functions of a police officer but were paid by, and accountable to, the client as opposed to the police force. The hiring of a large body of paid duty officers was the method the DYBIA used to address issues of safety and security. The results of the DYBIA's policing strategies will be the focus of this thesis.

The growth and development of law and order has resulted in changes throughout history. These changes in policing were the result of a change in public opinion and 
need. One such change was the development of a style of policing known as 'Broken Windows Policing' where public order and targeted policing were the focus' of police attention; a theory I will discuss in greater detail in chapter two (Wilson \& Kelling, 1982). The targeted individuals (such as the homeless, poor, etc.) became the 'undesirable' population to be dealt with by policing foot patrols who focused on order maintenance through a 'zero tolerance' policy. This combination of zero tolerance, targeted policing, and foot patrols manage the decay of the urban structures in major business centres such as Toronto (Hannigan, 1998). Broken windows policing was developed in 1982 in New York as a response to the increased level of crime. Police foot patrols targeted undesirable populations in New York in an attempt to remove elements that contributed to the onset and continual degradation of an area. Furthermore, private organizations wishing to address similar issues hired off-duty officers to perform duties using broken windows policing methods.

The difference between the use of off-duty officers by private organizations, such as the Downtown Yonge Business Improvement Area, and public police services is the ability to target their perceived undesirables. This occurs because public policing organizations are not allowed to target certain individuals; however, private organizations are able to target the populations they believe to be the source of fear, crime, and urban decay within their area of influence. Therefore, it is important that this thesis revisit the Merchant Security Satisfaction Survey of the Downtown Yonge Business Improvement Area in order to measure the effectiveness of a foot patrol program utilizing a broken windows policing philosophy that focused on the sources of fear, crime, and urban decay. 
The commodification and promotion of paid off-duty police officers, or paid duty officers, has raised questions of accountability, bias, and targeted policing. The question of accountability is raised as a result of two key organizations (DYBIA and the Toronto Police) with opposite expectations and demands. DYBIA requests that paid duty officers patrol a specified area and remove individuals they deem to be undesirable. The Toronto Police does not allow police officers to indiscriminately decide who they believe to be undesirable and remove them from the area. As a result, the conflicting operating procedures are often decided by the officer on an ad hoc basis with a view to who they will be accountable to when they are in a paid duty capacity. That is not to say that paid duty officers acting in a private policing capacity do not answer to their public police employers as well, or would commit an act that would be considered unforgivable by the precincts, who retain top priority. However, this dual accountability creates an opening for interpretation which often leads to bias and targeted policing. This bias arises out of the contractor or payee desiring certain responsibilities or demands of the paid duty officers to perform or carry out in accordance with their agenda. As a result, a bias is created towards a party, a situation, or an act.

Finally, targeted policing is a primary concern for paid duty policing, particularly for a broken windows policing style. This concern results from the legal and moral implications which ensue when individuals are deemed to be undesirable either by the police or by the Business Improvement Area, and are subsequently targeted for removal or mistreatment when there has been no actual wrong doing by that individual. Their "crime", in effect, is their undesirability, which is hardly a crime and which is hardly an acceptable legal or moral ground to remove someone. Therefore, the commodification of 
police powers raises questions of the legitimacy and use of policing powers by the private sector, whose goals and motivations may be questionable, when policing powers are meant to be used for the good of all people as opposed to a select few who can pay for the services.

This thesis discusses the results of one such program where paid duty police officers retained as private security providers by the DYBIA. The data results from an earlier study were compared to the data results collected for this thesis. The current situation in the DYBIA has changed as police officers are no longer paid duty officers but rather a police task force funded, sanctioned, and run by the 51 and 52 divisions of the Toronto Police Service.

The style of policing that the Business Improvement Area purchased was a broken windows policing style carried out through foot patrol programs. The police officers were hired to walk the entirety of the Downtown Yonge Street core enforcing rules and achieving the desires of the DYBIA. The foot patrol officers would visit each business owner to create a rapport and become familiar with the surrounding area in order to recognize the "undesirable individuals" who did and did not belong to the area. As the officers began to understand and recognize the distinctions between individuals, they began to target those individuals deemed undesirable and remove them from the area. The reason that foot patrol was used, as opposed to a quicker method of travel such as a bike or car, was a belief that officers "walking a beat" create a greater intimacy with the community. Foot patrol officers are directly on the street and therefore come into contact 
with individuals more readily, as opposed to a moving vehicle where they can travel through an area without really engaging with those living in the neighbourhood.

This thesis discusses the foot patrol's success in meeting the desires and goals of the DYBIA; it will also provide understanding of the positive and negative aspects of such a program, and how the use of a foot patrol program influences the perceived levels of risk and fear within a neighbourhood.

Risk and fear are two primary motivators for individuals, business owners, and organizations to seek protection from other sources. Sources such as the Toronto Police Service utilize a range of municipal, provincial, and federal powers that are not readily available to private policing services. An example of these powers would be arresting for panhandling and other offences. The need for increased police powers is a direct result of fear being "uncontrollable" (Beck, 1999). As the levels of fear begin to rise in a community, so does the perceived need for increased power and protection to reduce fear. Preventative crime control becomes a necessary and unavoidable aspect of when considerations of risk, fear and insecurity become important to community members. For example, walking down a path that is poorly lit increases a persons' feelings of vulnerability to potential crimes, while another person walking down a clearly lit path may not feel the same levels of exposure or vulnerability. Ensuring public thoroughfares are well-lit and well-maintained are examples of risk management techniques that are designed to address the levels of fear that one experiences associated with the risks presented by dark pathways, etc. 
This thesis discusses the risk management practices and designs that were and are in place within the DYBIA for the purpose of reducing risk and fear. Furthermore, this thesis measures the data of the merchant survey to evaluate the success of said designs and practices to determine the effectiveness of them, particularly where police foot patrols are concerned.

\section{Methodology}

The purpose of the study was to measure the effectiveness of the police foot patrol program in the Downtown Yonge Area Business Improvement Area. The primary source of data came from a survey which sought to uncover the opinions of a sample of Yonge Street Merchants affected by foot patrols in their community. More Specifically, this survey sought to gain a deeper understanding of the merchant's opinions of the foot patrol police, as well as how the use of foot patrol programs influence one's perceived levels of risk and fear in the downtown Yonge neighbourhood.

The primary method of the research was a Merchant Security Satisfaction Survey, which was designed to ask a series of questions surrounding concerns of safety and security within BIAs. The survey began by asking merchants about visits by police officers, as well as their general perception of crime within their geographical area of operation. The questions were designed to assess general feelings about safety and security in the target study area. The questions focused on the use of private security in the protection of the merchants' businesses. These questions give a general idea of the measures merchants take to protect their business, specifically, that which is above and beyond protection provided by the public police. The survey also asked questions about 
the merchants' perception of safety and fear in the area around their business, within their business, and beyond the target study area. Finally, the questions ask about police effectiveness in addressing a myriad of different issues that either could arise, or are already occurring within, the area. See appendix A for examples of the questions that were asked.

The questions that were asked in this survey were a continuation of earlier work that began in 2005 with Michael Gavendo and was continued in 2007 by George Rigakos. The continuation of this study permitted a longitudinal study of the effectiveness of the police patrols within the Downtown Yonge Business Improvement Area. The geographical boundaries of the area of study were from Alexander Street to Queen Street on the East Side of Yonge, and Grosvenor Street to Queen Street on the West Side of Yonge Street (see appendix B). Each business that was storefront was visited in person and asked to complete the survey. The surveys were completed by the student while asking and explaining each of the questions to the participant merchant or agent. If the merchant refused to take part in the survey, their name was crossed off the list as not participating in the study and not visited again. Merchants who requested that the survey be picked up at a later date had an appointment time made for retrieval. If the survey was incomplete on the appointed retrieval time, an extension was given and a new retrieval date was made. The extensions continued until all participant surveys were gathered or the merchant changed their mind and refused to participate in the survey. 
Area of Study

As previously mentioned, the area of study was from Alexander Street to Queen Street on the East Side of Yonge, and Grosvenor Street to Queen Street on the West Side of Yonge Street. Each storefront business was visited by the researcher and had the survey completed, refused, or retrieved at a later date. The reason for the specificity of storefront businesses was for the significance of police interaction and the ability to view street level foot traffics.

There were targeted times of delivery of the survey for the businesses within the area of study. The particular times were between 1 lam \& 4pm, and $7 \mathrm{pm} \& 11 \mathrm{pm}$. These targeted times permitted the researcher to approach the merchants during business hours. In many cases, the survey was left with the merchants and retrieved at a later date so it could be completed at their leisure.

There were a total of 111 participants in the survey out of a total of 144 acceptable businesses within the area of study, 82 of which are classified as small business $^{3}$ and 62 as considered large business or corporate entities ${ }^{4}$. Of the participating merchants, a large majority are privately owned businesses as opposed to large companies or subsidiaries; approximately, 58 small business and 53 large business or corporate entities were included in the study.

\footnotetext{
${ }^{3}$ For the purpose of this thesis, small business refers to any business that is privately owned and not affiliated or a subsidiary of a larger corporation or parent company as determined by this author. ${ }^{4}$ Large business or corporate entities refers to any business that is owned, affiliated, or a subsidiary of a larger corporation or parental company as determined by the author of this thesis.
} 


\section{Field Notes}

While travelling along the area of study, several observations were made of people, behaviours, and trends. Many of the people moving through the area of study were business people travelling to and from work and young adolescents looking for places to shop and/or meet friends. There appeared to be no apparent age group, race, gender, ethnicity, or culture that was given emphasis or draw. Rather, it appeared to be a business centre designed to draw in all types and people. While there was no apparent cultural, stylistic, or sexual preference, there was a clear economic separation in the businesses in the area; that is, most businesses priced their merchandise more towards the middle to upper-middle class as opposed to the lower-middle or lowest class.

The businesses were separated into small businesses and large/corporate businesses based on geographical location and product/service. The smaller businesses in the area of study were found to be farther away from Dundas Street (which has been identified as the middle of the area of study) while the larger/corporate businesses were found to be closer to Dundas Street. Furthermore, the businesses closest to Dundas Street were mainly of three different varieties: food, clothing, and entertainment. As one moved away from Dundas Street (either north or south), smaller businesses were found that offered a larger variety of goods and services.

\section{Additional Observations}

There were some particular notes that were made in regards to the research. The first observation that was made involves the visibility of police and the notable presence by merchants. In certain areas such as College Street and Dundas Street, merchants noted 
that police were much more visible. The reason for increased visibility in these two areas is directly related to geographical significance. In the case of College Street, police headquarters (51 division) is located at Yonge Street and College Street; due to this geographical significance, police frequent the area in higher numbers. This was also attributed to the locations of Starbucks and Tim Hortons which are also located on that comer. Dundas Street had high levels of foot traffic and is close to another police station, specifically 52 division. Dundas Square is also located on the corner, as well as the Eaton's Centre. Both locations were attributed to a high level of visibility by merchants.

The second observation made throughout the data gathering process concerns general attitudes towards personal safety and business safety within the area of study, which was generally one of "security". The merchants felt safe within the area around their businesses or along the Yonge Street. However, as one left Yonge Street and travelled on to other streets, the level or feeling of safety declined. Some merchants felt it safer to wait on Yonge Street for a bus or street than to walk to a neighbouring street to get their car.

Thirdly, the general attitude of merchants within the area of study towards police was one of respect; while some may not like the police, they generally they respect their work and are grateful for it. Most merchants believed that the police were doing a fair job of keeping the crime levels down regardless of response times, which seemed to be the area of greatest contention for merchants. Police response times were seen as too slow and follow-ups were seen as inconsistent.

Finally, the last observation that was made concerns the installation of cameras along Yonge Street by the Toronto Police Service. The vast majority of merchants 
believed that the use of cameras along Yonge Street would lead to increased feelings of safety. Some noted that the use of cameras would be for future reference if they caught a suspect and/or needed evidence, rather than a deterrent. Interestingly, there is some research that indicates cameras in the UK do have some deterrent effects (Coleman, 2004). Some merchants felt that with the camera system in place, the police would use the cameras to see if there was an issue that actually needed presence or attendance. If the situation was not a priority concern, often there is a longer response time. However, for the most part, merchants believed the installation of cameras along Yonge Street would have a positive effect on the neighbourhood; interestingly, there did not seem to be any issues around feelings of privacy for either merchants or their customers. A few merchants did note that if cameras were installed in the neighbourhood where they lived, it would be an entirely different issue. 


\section{Chapter 2: Risk, Commerce, and Business Improvement}

This chapter will focus on the theoretical considerations of risk and fear, policing, and commodification within Business Improvement Areas (BIAs). I will discuss how risk and fear have given rise to "risk markets", which have in turn influenced the police response in BIAs, specifically with regard to the use of foot patrols. I will review the purpose and theory of foot patrol as a police response within BIAs and discuss how it seeks to address risk and fear.

\section{$\underline{\text { Risk and Fear }}$}

Fear has become an issue of concern as it affects the way people approach their everyday activities. Frank Furedi (2006) describes how a "culture of fear" has come to permeate society:

"One of the distinguishing features of fear today is that it appears to have an independent existence. It is frequently cited as a problem that exists in its own right disassociated from any specific object. Classically societies associate fear with a clearly formulated threat - the fear of death or the fear of hunger. In such formulations, the threat was defined as the object of such fears. The problem was death, illness or hunger. Today we frequently represent the act of fearing as a threat itself. A striking illustration of this development is the fear of crime as a problem in its own right" (Furedi, 2006: 1).

This fear of crime that Furedi discusses is applicable to everyone as it is an idea that has evolved from a specified fear of an object (hunger, illness, death) to a fear for the sake of fear itself (Furedi, 2006). The pervasive nature of "fearing everything" legitimizes the need for social control, thus becoming a mechanism of control in society. Fear influences how an individual behaves or acts, or how an individual considers an act or behaviour. If 
there is a fear about a particular geographic area, an individual may change their route of travel in order to avoid it. Likewise, the fear of a particular person can have similar responses. Take for instance an individual walking down a street where a homeless person is present. While the response towards that homeless individual will be different from person to person, most pedestrians will have a certain level of fear towards that homeless person. Each person may ask themselves any number of questions including: Is this individual going to ask me for money? Are they going to mug me? Are they drunk? Based on the level of fear, numerous responses may pass through an individual's mind. One response may be to decide to cross the street rather than come into contact with the homeless person. Another response may be indifference. Regardless, there is a certain amount of calculation given to one's personal fear of associating with the homeless. This is, in part, because there is an association between fear and risk-taking behaviours. Risk-taking behaviours place emphasis on caution in the determination of action and responsibility. As Furedi discusses, "our culture of fear discourages people from taking risks. It is a culture that continually promotes precaution as a virtue and fosters a climate where risk-taking is equated with irresponsible behaviour" (Furedi, 2006: 9). The individual should avoid taking risks because it could potentially expose them to greater harm. Certain behaviours and actions are feared more because they are associated with high levels of risk. As a result, this ideology of risk management maintains control through the fear of harm and creates limitations on certain actions.

Another way to examine how fear controls actions through risk is to focus on the application and adaptation of the "hedonistic calculus" principle put forth by Jeremy Bentham (1970). Hedonistic calculus is a calculation that compares the list of pleasures 
gained versus the list of pains one can receive (Archambeault, 1984; Bentham, 1970; Bentham, 1995). If risk is added as a third variable to influence Hedonistic calculus, the calculation is altered immensely. Adding risk into the calculation, the individual must also calculate how much risk they are exposing themselves to in order to provide a balance to the calculation. An individual who wishes to ride a bike will weigh the benefits (fresh air, exercise, sunshine) versus the costs (time, energy, muscle pain or fatigue). They must also account for the risk of partaking in such an activity while on the road (cars, pedestrians, animals, etc.). In this example, the variable of risk is a determining factor on further incidences of pain. However, the levels of risk that the cyclist places upon himself may not influence the levels of pain but rather heighten the list of pleasures by adding excitement. In either case, risk is separated from pain and pleasure as it is an unforeseen variable which is beyond the control of the individual to calculate. It is because of this unforeseeability that risk is its own variable. It cannot be included in pleasure because it is unknown what pleasures may arise beyond those that can be identified. Similarly, it cannot be included in pain because it is unknown what further pain will be caused or what events might result from partaking in the act. Risk can be considered a variable in which a potential outcome might happen as opposed to will happen.

As a result, the variable risk can be viewed as two parts: 'real' fear and 'perceived' fear. Real fears are those that can be identified and associated with specific objects, people, places, or anything that can be accounted for: "Real fear refers to those that are tangible or associated with material fear (fear attributed to a known object)" (Pain \& Smith, 2008: 9; Vanderveen, 2006: 147). Perceived fear involves those fears that 
cannot be accounted for or identified. They are unidentifiable fears because there is no way of knowing what will cause a reaction of fear or how this cause will affect any situation: "perceived fear refers those fears that cannot be linked to material fears. They are the unknown fears of fear" (Pain \& Smith, 2008: 9; Vanderveen, 2006: 147). The individual, in an attempt to manage those fears, will reduce the amount of risk they are exposed to so as to keep the potential for increased pain to a minimum. In the example of the cyclist, cars, pedestrians, and animals exemplify "real fears". They are fears that can be associated with material objects; objects that are easily identifiable as pertaining to risk. Perceived fears are fears that are unknown; the ones that cannot be attributed to any particular object, but must be accounted for nonetheless as they could potentially cause pain.

We must include in the risk variable the possibility that there will be unforeseen circumstances regardless of how much foresight there is. This is furthered by Ericson and Haggerty's (1997) discussion of risk in relation to external danger (manufactured risk) and risk communication. The manufactured risks discussed by Ericson and Haggerty (1997:17) involve those risks which are created through human involvement for the purpose of influencing the "conditions and nature of social life". Or rather, in the attempt to manage the unknown risks through intervention, we attempt to control risk. As such, Ulrich Beck wrote that:

"Risk is the modern approach to foresee and control the future consequences of human action, the various unintended consequences of radicalized modernization. It is an (institutionalized) attempt, a cognitive map, to colonize the future" (Beck, 1999: 3).

Beck describes above a method in which society feels it can better manage the potential dangers of its surroundings, which has also been discussed by scholars such as Feeley 
and Simon (1994) and Rose (2000). For Feeley and Simon (1994), risk is determined by statistically predictive techniques for the purpose of minimizing harms. Rose (2000) adds that risk also includes non-statistical techniques to address uncertainty. The combination of these definitions is that risk in a "risk society" is the use of information, both statistical and non-statistical, for the purpose of identifying threats, issues, and concerns that impact society in order to safeguard against them.

It is for this reason that risk, and its interrelationship with fear, is essential for hedonistic calculation as there are potentially hidden pains or pleasures that are not included in the basic calculation. Control agencies emphasize risk and fear for the purpose of managing the individual as they attempt to prevent risk-taking behaviour. Ericson and Haggerty (1997) would refer to the use of media outlets as a means of disseminating risk information as "risk communicators". Risk communication refers to the communication of "rules, formats, and technologies used to manage dangers" (Ericson \& Haggerty, 1997: 17). Risk communicators are not restricted to just media outlets, rather, they involve many sources of information (word of mouth, businesses, insurance companies, etc.) that suggests, mentions, pushes, advertises, or influences the need for risk prevention products or behavioural modification (Ericson \& Haggerty, 1997).

The use of risk and fear as a mechanism of control, either through risk products or behavioral modification, not only apply to the individuals, they can also be applied to society in general (Furedi, 2006; Pain \& Smith, 2008). The variable of risk is constantly reinforced by media outlets and consumer products which push the mentality of victimization. Examples of a flourishing market in fear include sports utility vehicles, 
child tracking devices, organic food, burglar alarms, outdoor lights (Furedi, 2006: 3; Pain \& Smith, 2008: 1). Each of these examples pushes the idea that if these products are not utilized, the individual is engaging in risk-taking behaviour which will increase the potential for pain. It also pushes the mentality that if a person does not cease to engage in risk-taking behaviours, they are irresponsible.

The media and other agencies also promote anxiety, insecurity, and uncertainty as manageable factors that a responsible individual can account for. Responsibility is placed on the individual because the choice to not acquire or subscribe to risk minimizing products is an individual decision. If the individual is hurt as a result of their choice to not employ risk minimizing products, then blame cannot be directed towards any other source. As a result of such circumstances, society adopts behaviours that emphasize minimal risk-taking and risk preventing measures.

The emphasis of fear and risk placed upon society and individuals is further enforced upon business owners. Business owners require the same risk preventative measures that non-merchants require, with the exception that risk preventative measures are pushed more heavily with the former group as a necessity instead of a choice (Neocleous, 2008). The risk preventative measures that are focused upon in businesses fall under the category of 'loss prevention' (Ericson \& Haggerty, 1997: 29). Loss prevention is the new focus for companies as it is not concerned with increasing profits, but rather, the concern is on minimizing losses. As such, one of the preventative measures which merchants are strongly encouraged to use is private security in the protection of their businesses. The message that is delivered to merchants is that if they desire to protect their businesses, their livelihoods, they must employ the means to 
protect it. In some cases that means the use of private security to prevent shoplifters. Other cases might involve the use of bars on windows and security alarms or cameras. If the owner of the business does not employ any means with which to lower the risk to their business, then there is no one else to blame but themselves.

\section{Commodification}

As a result of the emphasis by risk society to manage risks through fear, a market for risk management has become prevalent. This market constitutes all of the riskpreventative and fear reduction measures that the media and other agencies promote to manage anxiety, insecurity, and uncertainty. These measures have become the means with which fear and risk have become commodified: "In simplest terms, commodification refers to the incessant expansion of capital and, by extension, the transformation of aspects of human existence into commodified form" (Rigakos, 2002:24). Risk markets, as commodified preventative measures, offer a wide range of products and means that are designed to manage the fears and risks that an individual may experience. The use of alarms, cameras, private security, and other preventative measures are only a small portion of the preventative measures that are offered within risk markets. They exist primarily by exploiting sources of fear; the products are created and sold under the guise of a need. As Furedi (2006) mentioned above, people fear for the purpose of fear itself. As a result, risk markets create products that are designed to alleviate fears that people have not even considered or were even aware of until products are marketed and sold to them, to respond to the newly-found fear. 
However, not all risk markets are created as precursors to fear and risk as some products are created in response to a specific need for preventative measures. The idea supporting such markets is that risk is constant and ever growing. The risk market is one that exists as both a proactive and reactive market (Rigakos, 2002). The proactive measures, which have been discussed above, concern those that have yet to occur but might occur. These products are created to prevent harm before they occur by anticipating risk. The reactive market, which is closely tied with the proactive market, offers products and services that respond once the proactive measures have failed. An example of a reactive market is public and private policing, or rather, the commodified police.

The commodified police, both private and public, have become a massive resource within the risk market. Private security agencies that offer a forceful presence in the protection of property or people have grown significantly over the last several decades. Some of the businesses such as Group 4 Security, Intelligarde, and Garda have become major names within the security field. With this said, it is important to note that the protection they provide comes at a price. The range of powers and training that are associated with private security is limited in comparison to public police officers. Furthermore, the legal authority that is attached with private security is minimal at best. As such, businesses and agencies requiring the authority and training of a professional can hire public police.

Public police have also become a major commodity as hired security; specifically, being used in larger numbers much like the private police. The public police can be identified as being commodified in two ways. The first way in which public police are 
commodified is through paid duty, which connotes that police officers offer their services to the private industry independent of the police force. Officers, on their days off, can be hired to fulfill a variety of roles for a price. The price is agreed upon by the officer ahead of time as well as the exact duties they will perform. Though off duty, the officer maintains his police powers as if on duty; this includes all the powers and authority to enforce the laws, as well as being armed. As these services cannot be offered by private security, individuals who require or desire the full range of protection can now hire a public police officer as a means to gain that protection. The second way in which police are commodified involves foot patrols inside the boundaries of Business Improvement Areas. There is a distinct difference between paid duty details and foot patrols inside BIAs. The difference lies in the fact that the foot patrols are paid for by the BIAs, but not paid directly to the police officers themselves. Rather, the payment for services goes directly to the police department in which the officers are dispatched from. The police officers are not consulted by the BIA representatives regarding their duties; their responsibilities are determined by the police department itself. The BIAs pay for a service to be rendered within the geographical area under their management without discussion or interaction with the individual police officers that will be performing the foot patrols.

\section{Business Improvement Areas}

The rise and coordination of Business Improvement Areas (BIAs) around the world offer the promise of revitalizing business districts through increased trade, 
competition, and most of all, safety and security. The overarching idea of a Business Improvement Area is to ensure the proliferation, growth, and the protection of merchants and non-merchants. Businesses within the boundaries of BIAs pay the organization to look after their common interests, such as the condition of the streets and storefronts, enforce municipal by-laws, sustain market values, etc. All of the interests specifically target the increased wealth and business for all within the area and the continual movement of goods. The BIAs monitor their area in terms of structure, coordination, and value (Hosse \& Przybylowski, 1976). First, the structure of the BIA maintains that all merchants within the borders of the BIA must be involved in the BIA, even if only financially (Ellickson, 1998). Since the BIA looks out for the greater good of all merchants within the area, all merchants benefit from this must fund the BIA equally. Secondly, the coordination of the area involves many different aspects concerning its aesthetics, feasibility, and accessibility ${ }^{5}$. Some of these aspects include: lighting, parking signs, directional signs, bus signs, and turning signals, sidewalks in good repair and uniform, benches, planters, refuse containers, trees, traffic lights, pedestrian walk signs, and road paving (Hosse \& Przybylowski, 1976). The desired outcome of the coordination is to, "bring new life, increase traffic flow, pleasant area, confidence among the merchants, city involvement, merchant involvement, and fewer vacant stores" (Hosse \& Przybylowski, 1976: 28-30). And thirdly, the value of the area must be protected and maintained similarly to the coordination of the area. Much of the protection of the value of the area comes from "Area Beautification" (Hosse \& Przybylowski, 1976: 71-72). The concept of area beautification revolves around the idea that the appearance of the area is directly related to the success of the business. If the area has deteriorated, both

${ }^{5}$ http://www.downtownyonge.com. Downtown Yonge Business Improvement Area website (2010) 
economically and physically, (i.e. beginning to accumulate garbage), then there is an increased chance that business will decline, and the state of the area will follow suit. As such, "Beautification provides an atmosphere conducive to impulse shopping and an environment that will encourage customers to return. A pleasant place to stroll, a happy place to chat, to meet one's neighbour and, of course, to shop" (Hosse \& Przybylowski, 1976: 71-72). The manner in which the trees are planted, the lighting is spread out, the availability of benches or other furniture, garbage on the streets, and other factors are involved in the beautification of an area, and ultimately in the protection of the property's value.

The BIA's create social centres of commerce and interaction among merchants and non-merchants. These social centres also act in many ways as repositories of not only wealth, but also culture and knowledge:

"In short, they are centres of social and political life where not only wealth is accumulated, but knowledge (connaissances), techniques, and oeuvres (works of art, monuments). This city is itself 'oeuvre', a feature which contrasts with the irreversible tendency towards money and commerce, towards exchange and products" (Lefabvre, 1996:66).

This economic and cultural centre (oeuvre or fantasy city ${ }^{6}$ ) allows the interaction between the business owners and non-business owners to occur en masse for the purpose of exchange. However, as with any area that is designed to draw people towards it, there is a likelihood that it will attract both desirable and undesirable individuals. The desirables are those who have money or resources for economic exchange with the business owners, while the undesirables are the opposite, and include troubled youths, the homeless, or

\footnotetext{
${ }^{6}$ See Hannigan, John (1998) Fantasy City: Pleasure and Profit in The Postmodern Metropolis. New York: Routledge.
} 
poverty stricken citizens, etc. As Neocleous, paraphrased from Hegel's The Philosophy of Right, states:

"When a large mass of people sinks below the level of a certain standard of living...that feeling of right, integrity, and honour which comes from supporting oneself by one's own activity and work is lost. This leads to the creation of a rabble...Poverty in itself does not reduce people to a rabble; a rabble is created only by the disposition associated with poverty, by inward rebellion against the rich, against society, the government, etc." (Neocleous, 2000: 48; Hegel, 1942:150)

The gathering of undesirables, particularly in large numbers, within any given area begins to cast the area in a negative shadow as a result of the perception of fear. The undesirables are seen as a source of fear for both merchants and non-merchants alike. This negative shadow results in reduced business, reduced pedestrian traffic, and a degradation of the area. They are the antithesis to the purpose of the BIAs to restore the area, protect the movement of goods, and monitor order. As such, the undesirables are policed in order to minimize this negative shadow. The method often used in the policing of undesirables is foot patrol ${ }^{7}$; BIAs hire the services of police officers to walk through and monitor their area of responsibility.

\section{Foot Patrol}

Foot patrols involve police officers who walk and monitor a designated area. Specifically, foot patrol is, "defined as the routine movement of uniformed officers...on foot through delineated geographic areas" (Schell et. Al, 1976: 6). This form of patrolling method has five basic goals. The first goal is the deterrence of crime (Schell et. $\mathrm{Al}, 1976: 6)$. As the uniformed officer travels through the delineated geographic area,

\footnotetext{
${ }^{7}$ Read Gavendo, M. J. (2006). Toronto Public Policing for Hire: The Effects of Commodification of Policing Services in the Downtown Yonge Business Improvement Area. Carleton University, Ottawa.
} 
their presence acts as a deterrent to individuals who would consider committing a crime (Newark Foot Patrol Experiment, 13; Schell et. Al, 1976: 6). As police patrol the area inside of a BIA, their presence is noted by the merchants, non-merchants, and the undesirables. The level of "notice" is different for each group. The merchants will notice the foot patrol officers less than non-merchants or undesirables as their attention is focused primarily upon their business. They will be more attentive to what transpires inside their business rather than outside of their business, however, this is not always the case. Some merchants are acutely aware of the presence of police within their area or within the vicinity of their stores. Non-merchants will also notice the officers as they walk the street. These individuals are more likely to take notice of a foot patrol officer than merchants because they are outside of the businesses and on street level more than merchants. However, the "targeted population" will take notice of foot patrols within the BIA. These "undesirables" will notice foot patrols because of their potential to impact their lives. They are aware that police officers are keeping a watchful eye on the streets, and in some cases, specific individuals. As such, the greater the visibility of the police equals the decreased likelihood that those deemed to be undesirable will act in a manner that will bring them into contact with those police officers.

The second goal of foot patrol is the apprehension of criminal offenders (Schell et. $\mathrm{Al}, 1976: 8)$. Following the failure to deter crime, the police officers are responsible for the apprehension of the criminal. The apprehension of the criminal is also directly linked to the reinforcement of deterrence (Schell et. Al, 1976: 8). If the police officers are able to quickly apprehend the criminal(s), other individuals will notice the speed and efficiency of the apprehension and will be deterred further. 
Third, foot patrols aim to satisfy public demand for a range of non-crime related services (i.e. information on how to secure their businesses more effectively). Crime deterrence and apprehension is only a part of the duties of police officers. They are also responsible for giving emergency first-aid and rescue services, resolving disputes (both domestic and non-domestic), taking insurance reports, and many other services (Newark Foot Patrol Experiment, 13; Schell et. Al, 1976: 15).

The fourth goal of foot patrol is to strengthen a sense of community security and reinforce one's confidence in the police and the police force (Newark Foot Patrol Experiment, 13; Schell et. Al, 1976: 17). As the officers travel along their route through their geographically designated area, the merchants and regular non-merchants (those that work nearby but do not work directly within the route) will begin to recognize the officers that are patrolling their area. In some cases, the patrols will become familiar with the merchants and regulars that frequent their area as well. As merchants, nonmerchants, and patrols become more familiar with each other, they will begin to build a rapport with one another. This relationship is crucial for police officers when they are in need of assistance from merchants and non-merchants. If there is a sense of community security within a particular area, most individuals will be willing to offer assistance to police officers when they ask for it. This allows police to apprehend criminals and protect the public more efficiently. As the police become more efficient in their ability to address crime and elements of crime, confidence in the police is reinforced.

Finally, the "recovery of stolen goods, except for recovery of stolen cars, is achieved only incidentally to the realization of other goals" (Schell et. Al, 1976: 19). The recovery of stolen goods is an outcome of the other goals, because if other conditions are 
in place, not necessarily all conditions, the police have a greater chance of success in the recovery of stolen goods. Furthermore, the effectiveness of the police in recovering the stolen item can be measured. If the sum total of goods recovered is compared to the sum total of goods stolen, the resulting difference will determine the effectiveness of the police to recover stolen goods. Similarly, the amount of time it takes to recover the stolen goods will also reflect police effectiveness. If the police are able to recover the goods in a relatively short period of time, the effectiveness of the police is reflected positively. Conversely, if the time required to return the goods, or not return the goods, is too long, the effectiveness of the police is reflected negatively.

The use of foot patrol in the policing of "undesirables" in BIAs works under the principles described above. Foot patrols must maintain a presence within the BIA in order to deter criminal activity. Furthermore, the presence of the police will also allow a greater opportunity to apprehend the criminal. The ability of the police to apprehend criminals is also influenced by the merchants' and non-merchants' co-operation with the police. If the police have managed to reinforce the confidence of merchants and nonmerchants, they will be more likely to help police in kind. The police can reinforce the confidence through proactive policing such as foot patrols, as well as strengthening the community security by talking with the merchants and becoming familiar with them. If the police are known, either by name or by recognition, the mentality of "us and them" will begin to erode (Newark Foot Patrol Experiment, 13). Similarly, police officers can become more familiar with the patterns and physical characteristics of his area. This will aid the officer in anticipating incidences before they can occur as well as create opportunities for greater sources of information (Newark Foot Patrol Experiment, 13). 
It is through the use of methods such as foot patrol that policing has become, as Neocleous paraphrased Colquhoun, the force that stands between the individual and the universal for a common interest (Neocleous, 2000). In other words, Neocleous writes that police are concerned with providing security as well as, "welfare, street-lighting, bridge-building, the pricing of daily necessities, public health, and the founding of colonies" (Neocleous, 2000: 47). The use of foot patrol in the prevention of crime and misdemeanours are what Colquhoun (1795) considered to be the "true essence of policing" (Neocleous, 2000: 47). Furthermore, these police practices that Colquhoun considered the "true essence of policing" are the main ideas that other risk theorists such as Beck (1999), Hegel (1974 \& 1991), Foucault (1995), Bentham (1995), and Neocleous (2000\& 2008) have also considered to be the essential determinants of preventative policing. This is recognizable in the many of the ideas that can be found in risk literature such as panopticism and the panopticon as discussed by Bentham and Foucault as these are applied to surveillance and Closed Circuit Television. Furthermore, other ideas of preventative policing and risk management have developed many different styles or forms ${ }^{8}$. An example of a policing style that utilizes risk theory and foot patrols as a preventative measure, is Broken Windows policing which specializes in order maintenance.

\section{Broken Windows policing style}

The use of order maintenance policing has the resulting effect of minimizing the fear of travelling into urban centers, and the risk that one assumes. Urban areas which are managed by BIAs and police task forces are of particular importance in terms of risk

\footnotetext{
${ }^{8}$ Read Bright (1970), Pendland and Gay (1972), and Bloch and Ulberg (1972)
} 
and fear management. BIAs, recognizing that minimizing fear and risk are vital to capitalism and urban resuscitation, seek the assistance of the police, merchants, and the general public in identifying sources of risk and fear. Once these sources, such as undesirables, are identified, they are then able to address the issues in the most effective and efficient means.

This order maintenance policing style is also referred to as "Broken Windows" policing. Broken Windows, written by James Q. Wilson and George Kelling in the 1980s, examines the perceived success of the New York Police Department (NYPD) to combat street deterioration. The paper discussed 'Urban Decay', 'Order Maintenance' policing, and the idea that "serious street crime flourishes in areas in which disorderly behaviour goes unchecked" (Wilson \& Kelling, 1982: 34). Wilson and Kelling outlined the methodology used in the policing of disorderly behaviour within crime ridden areas, and the perceived outcomes. The scholars argued that there was a slippery slope in effect in which one event cascades into another and so on and so forth:

"A piece of property is abandoned, weeds grow up, a window is smashed. Adults stop scolding rowdy children; the children, emboldened, become more rowdy. Families move out, unattached adults move in. Teenagers gather in front of the corner store. The merchant asks them to move; they refuse. Fights occur. Litter accumulates. People start drinking in front of the grocery; in time, an inebriate slumps to the sidewalk and is allowed to sleep it off. Pedestrians are approached by panhandlers" (Wilson \& Kelling, 1982:32).

Wilson and Kelling labelled this progression of events as urban decay, a process in which a neighbourhood slowly degrades into social confusion and disorganization. They argued that as neighbourhoods become decayed, fear amongst the citizens will rise (Wilson \& Kelling, 1982). For Wilson and Kelling, this 'fear amongst the citizens' was crucial to the effectiveness of an officer's ability to address and eliminate crime. As fear rises 
within the neighbourhood, people begin to withdraw from one another and bonds weaken. As these bonds weaken, the willingness to help one another erodes, until there is no longer a desire to help, and assistance available to police in addressing crime is diminished. The end result is that the police are eventually unable to do their jobs efficiently and effectively (Wilson \& Kelling, 1982).

In order to counter this decayed state, the use of order maintenance policing can be applied. Order maintenance policing was designed to target early incidents of urban decay by removing the marginalized before they are allowed to accumulate (Wilson \& Kelling, 1982). In an example from their text, Officer Kelly approached anyone (including drunks, drug addicts, loiterers and strangers) who were not conforming to the unwritten code of his street. If they were in violation of the unwritten rules (such as: drunks sleeping on stoops, visible liquor bottles, disruptive behaviour or loitering), they were asked to move along. If they refused, or continued to engage in the behaviour in question, then they were arrested for vagrancy (Wilson \& Kelling, 1982). The purpose of this form of policing was to prevent the onset of urban decay and to reduce incidences of crime in the area by removing any undesirables.

The current methodology of policing in BIAs continues to follow this style of policing that Wilson and Kelling put forth. Police target "undesirables" in the area and have them removed before they cause the chain of events inherent in urban decay (Wilson \& Kelling, 1982). The constant battle with urban decay is also coupled with the need and desire to manage the fear associated with those deemed to be undesirable and the risk perceived to reside in their presence for both merchants and non-merchants. 


\section{Broken Windows Debates}

The broken windows policing style, previously discussed, has been the topic of discussion for academics since its introduction in 1982 by Wilson and Kelling. Some of the issues that have been raised by academics include the relationship between crime and incivilities, suggested by Wilson and Kelling, were considered to be too causally linked; the inconsistency of the success of broken windows from one area to the next; and the developmental sequence of urban decay and broken windows measurements.

The link between crime and incivilities that Wilson and Kelling proposed created a relationship in which one directly correlated with another. For example, if crime was high in an area, then there was a high level of incivility in the area and vice versa. However, as Roger Matthews (1992) discussed as a flaw inherent in such a policing method,

"Crime and incivilities can and do occur together - but not always. Some areas have high crime rates and low levels of incivilities, just as there are areas with high incidence of incivilities and relatively low levels of crime" (Matthews, 1992:

22).

Matthews discussed how in some areas there was a high incidence of crime while maintaining a low level of incivility. Conversely, some areas that Matthews studied indicated a high incidence of incivilities while maintaining relatively low levels of crime (Matthews, 1992). Matthews also drew upon a study by Tim Hope and Mike Hough (1988), which was specifically designed to test the degree to which incivility and crime levels actually do relate. The study indicated only a loose relationship between incivilities and crime (Hope \& Hough, 1988; Matthews, 1992: 24). Furthermore, additional studies have found similar findings between incivilities and crime, and some 
believe there is no relationship (Eck \& Maguire, 2000; Harcourt, 1998; Novak et al., 1999; Sampson \& Cohen, 1988; Taylor, 1999; Taylor, 2001). Hope and Hough also suggest that, despite the loose relationship, incivilities potentially have a strong influence on the feelings of personal and neighbourhood security (Hope \& Hough, 1988; Matthews, 1992).

The influence of order maintenance policing on a neighbourhood's personal and community security, to which Hope and Hough (1988) refer to, is another issue that academics have discussed. The extent to which a neighbourhood will be influenced by order maintenance policing philosophy differs based on the conditions in which the neighbourhood is in. Matthews argued that measuring the extent to which neighbourhood decline is affected by incivilities is extremely difficult to measure, as conditions are rarely consistent, and triggers are rarely the same (Matthews, 1992). Similarly, the conditions which affect neighbourhood safety are equally as difficult to measure (Harcourt 1998).

Crimes and incivilities are both affected and defined by time and space (Harries 1999; Herbert and Davidson 1994; Loukaitou-Sederis 1999; Matthews, 1992, Painter 1996; Skogan 1990). Time and space are variables that play a critical role in distinguishing the relationship between victims and offenders within differing neighbourhoods. The response to a crime within poverty stricken areas, where crime is already considered high, is different from crimes committed in areas with lower levels of crime. Similarly, the response to incivilities such as litter, graffiti, and disorder is different within areas of high crime versus areas of low crime (Matthews, 1992; Skogan, 1990). The reason for this difference in response is attributed to the sensitivity of the 
residents. Matthews wrote that the residents in low crime areas are more sensitive to crime and incivilities because they are less likely to have experienced them over a long period of time (Herbert and Davidson 1994; Loukaitou-Sederis 1999; Matthews, 1992).

As a result, the accuracy of the developmental sequence is different between different neighbourhoods (Harcourt 1998). Matthews argued that the rate of urban decay would occur at different rates and manifest differently depending on the area where it occurs. Studies that focused on broken windows policing as the direct cause in the change of crime and incivility do not account for other factors that may be involved in the change in crime and incivility. For example, Greene (1999) compared San Diego and New York crime rates in order to compare policing methods. San Diego used a community policing style that involved the citizens in the area. Greene (1999) found that both cities experienced decreases in crime and incivilities using different sets of tactics. As such, Greene (1999) concluded that, "aggressive patrol is by no means a necessary component of crime reduction strategies" (Herbert, 2001: 451)

Moreover, Herbert (2001) discussed how police believe that, "Crime occurs in neighbourhoods, the theory declares, because residents allow it to occur. Residents do not fix broken windows; they do not confront loitering teenagers; they do no intimidate vagrants. Their neglect enables crime to flourish. Unable to do the job themselves, residents must rely on the police and their coercive power to re-establish order" (Herbert, 2001: 450)

Herbert wrote that the mentality of police in areas where broken policing styles are used to address urban decay was one of dominance over a weak population. In the case of the DYBIA, despite arguments and continuing discussion on the merits and deficiencies of a Broken Windows policing style, The DYBIA utilized this method. However, the DYBIA 
involved the merchants as part of the order maintenance policing style and to assist policing agencies.

\section{Merchant - Police Relationship}

Fear and insecurity are motivating forces behind the logics of prevention that fuel police deployment. People have become accustomed to addressing their insecurities with more and more security commodities. This is evident through the growth of security products and the expansion of private security companies as discussed previously. The most important security commodity has always been state policing although this has increasingly been supplanted by private security provision. What better way to satiate fear and insecurity than to actually "privatize" as much as possible general police provision in the form of foot patrol? Merchants are re-imagined as "clients" and the police as "service providers". By this logic entire downtown urban spaces become reconfigured as consumption destinations. The clients are provided a service that allows for them to communicate their desires directly to the service provider. As such, the police begin to act more and more like private security providers. Foot patrol, therefore, is one historically established vehicle to build public trust, create excellent client satisfaction, and directly deal with the incivilities of urban life that stunt a pleasurable shopping experience. Consequently, foot patrol and the establishment of a broken windows philosophy would be a logical extension configuring urban spaces along the lines of "business improvement" and the reduction of fear.

Moreover, the relationship, which started as client-agent, has evolved from the arrangement to the current one whereby the relationship reverted back to public-private. 
However, the arrangement is still one in which policing agencies are used as preventative security measures. Merchant fear and insecurity continue to dictate the relationship between merchants and police, as the merchants view the police as synonymous with security.

Despite the discontinuation of the private sponsorship by the Business Improvement Area, police foot patrols maintain the service as a necessity and a basic service befitting a major business centre. This is evident in the chapters following which outlines the data of the police performance in the Downtown Yonge Area. Merchants still rely upon police involvement in the protection of their business. The fear the merchants associate with undesirables drives them to seek out services and commodities that reduce that fear and insecurity. However, the hiring of police for the purpose of patrol is no longer available to the merchants in the DYBIA. Therefore, merchants and BIAs will continue to seek methods that can eliminate fear and insecurity. In this particular thesis, the use of foot patrol was the most effective method chosen by the BIA to carry out the intended purpose.

\section{Summary}

This chapter has discussed how risk and fear have become a way of life. Almost every individual considers the risks they assume in every situation, as well as evaluate the levels of fear they experience. Such perceptions and anticipations of risk have fostered markets to minimize the risk and reduce the levels of fear. Within these risks markets, there exist many different kinds of measures, one of which includes policing measures. The police have become a part of the risk market because of the services they offer to the 
public and private organizations, such as the Business Improvement Area. A BIA is created to protect the continued interests of all the merchants within the designated location. This protection extends beyond the merchants themselves to the nonmerchants, and both groups rely on the police to keep them safe and secure. In response to this reliance, Toronto Police patrol within the BIAs, such as the Downtown Yonge Business Improvement Area, more frequently. These foot patrols use a broken windows style policing method which specializes in order maintenance. The premise behind such a style is that if the area looks like it is in good shape and void of crime, individuals will think there is minimal or no crime. The police use their authoritative position as legal representatives of the people and the city to gain the compliance of any individual perceived to threaten order in any manner. Moreover, the police manage and attempt to reduce the climate of fear and risk through the policing of any so-called undesirables present in these areas.

The next chapter will discuss the data gathered in this study tracking the opinions of the merchants in the Downtown Yonge BIA in Toronto and the effectiveness of the Foot Patrol program, initiated originally by the BIA and later as a special task force, in addressing crime within the BIA. 


\section{Chapter 3 - Initial Analysis}

The MSSS measures the levels of fear of crime, response to policing agencies' activities, safety and security. This chapter outlines the questions of the survey and explores the data results gathered from this study. Particular emphasis will be given to the responses to questions relating to the fear of crime as a measurement for the effectiveness of foot patrol within the DYBIA. The questions and the results of the questions will also be used in the following chapters in order to discuss important comparisons between the data sets gathered from this research project and the previous research projects mentioned in chapter two.

\section{Perception of Safety and Levels of Fear}

The MSSS asked the merchants a variety of questions concerning their perception of safety in given situations along Downtown Yonge Street. The data results in figure 3.1 showed that overall merchants felt reasonably safe in every situation that was asked of them. There was no situation in which the majority of merchants felt there was a safety or security issue. However, there was also a high recording of merchants that felt reasonably unsafe when they were alone in their business ( 22.5 percent) or when they were walking to a parking lot that was off of Yonge Street ( 22 percent). This means that the merchants felt that when they were in their own business or when they travelled off of Yonge Street they felt their safety was diminished slightly. This can be attributed to the lack of visibility within their business or travelling off of Yonge Street. Similarly, in the other situations where they are primarily on the street (i.e. walking past someone, waiting for a bus, using public transit), the merchants felt there was minimal or no safety issue. 
This can also be linked to the visibility along Yonge Street through pedestrian traffic, presence of Toronto Police Foot Patrol, and DYBIA's environmental design. All of these sources can be a deciding factor towards the feeling of safety on Yonge Street.

\section{Figure 3.1 - Merchant Perception of Safety}

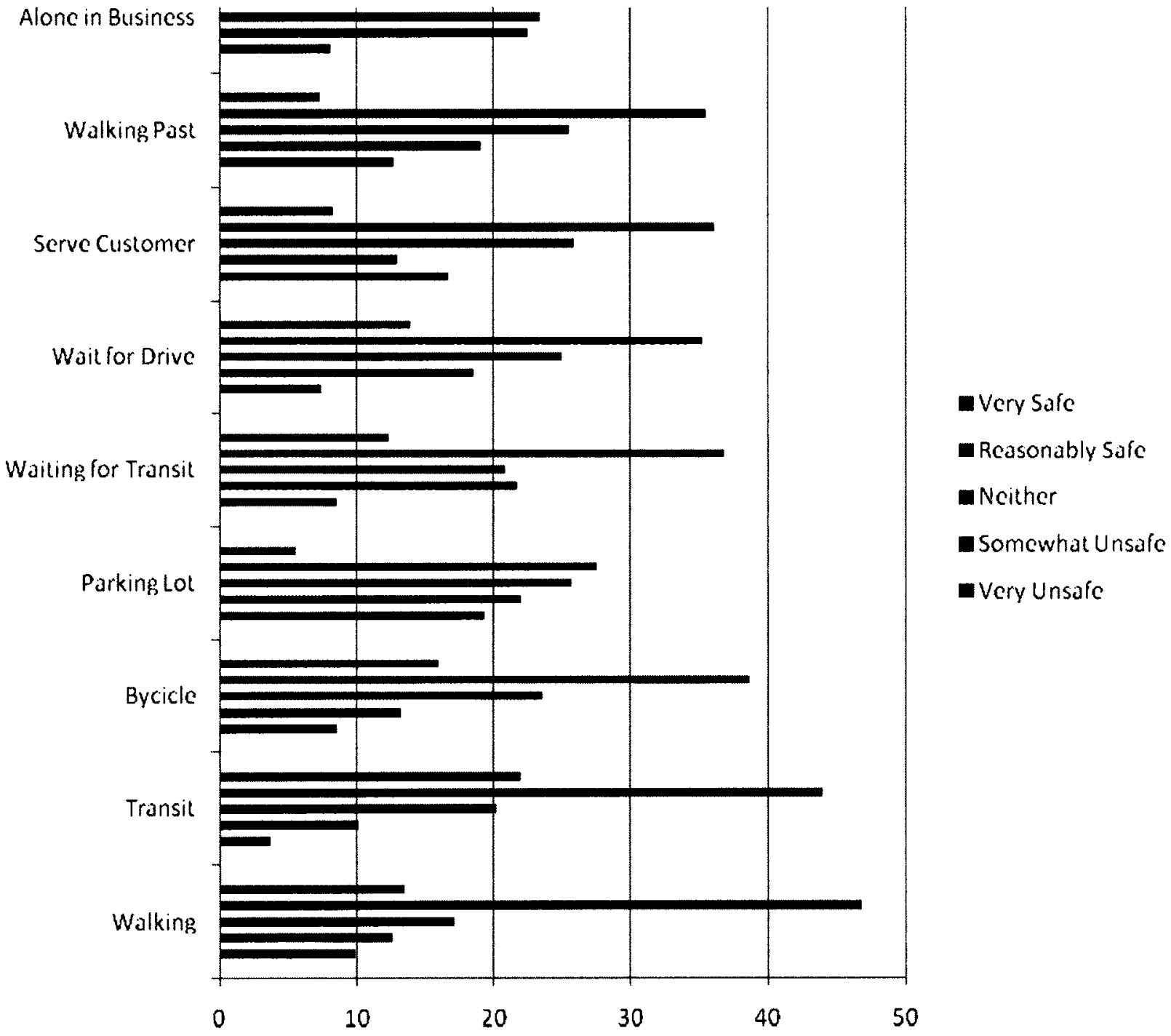


In order to determine the sources of fear that merchants were most concerned about, the merchants were asked to identify the behaviours they feared most, both in their businesses and when they were travelling along Yonge Street. The majority of merchants felt that the sources of fear they were concerned with included theft, loitering, panhandling, violent assault, burglary, drug dealing, drinking and using drugs (Figure 3.2). Of these issues, theft ( 75.7 percent), burglary ( 57.7 percent), and panhandling (56.8 percent) were the three sources of fear that they were most concerned with. These three sources of fear that were identified by merchants are the three major concerns that business owners are primarily concerned with, particularly in city centers. Theft and burglary can be identified as the most obvious concerns for merchants as their products being stolen means they lose money. For some of the smaller businesses, the loss of their products can be a significant loss to the business and thus is feared heavily. Similarly, the damage associated with burglary can also be expensive to fix or replace.

The issue of panhandling can be attributed to both the business and personal safety along Yonge Street. Panhandlers can be negative deterrents to customers desiring to enter a store. As discussed in chapter 1, panhandlers (and homeless people in general) can be sources of fear that will influence a persons' decision whether or not to enter a business. Panhandlers can also be a source of theft and burglary as well as solicitation of the merchant.

The majority of merchants were not concerned with robbery, garbage, graffiti, youth gangs, teenagers or vandalism as sources of fear. Specifically, 70.3 percent of merchants were not concerned with graffiti, 68.5 percent were not concerned with garbage, and 67.6 percent were not concerned with teenagers. These issues were mostly targeted by the 
Broken Windows style policing, as previously discussed in Chapter 1, which targeted these problem areas with the use of foot patrol in order to remove these issues as sources of fear. With the exception of panhandlers (and homeless), graffiti, teenagers, vandalism, garbage, and youth gangs were all successfully targeted by this strategy and as a result of such targeting, whether by direct intervention by police or coincidental success, the merchants along Yonge Street feel that these issues are no longer a concern towards their business or their person.

Figure 3.2 - Perceptions of Fears

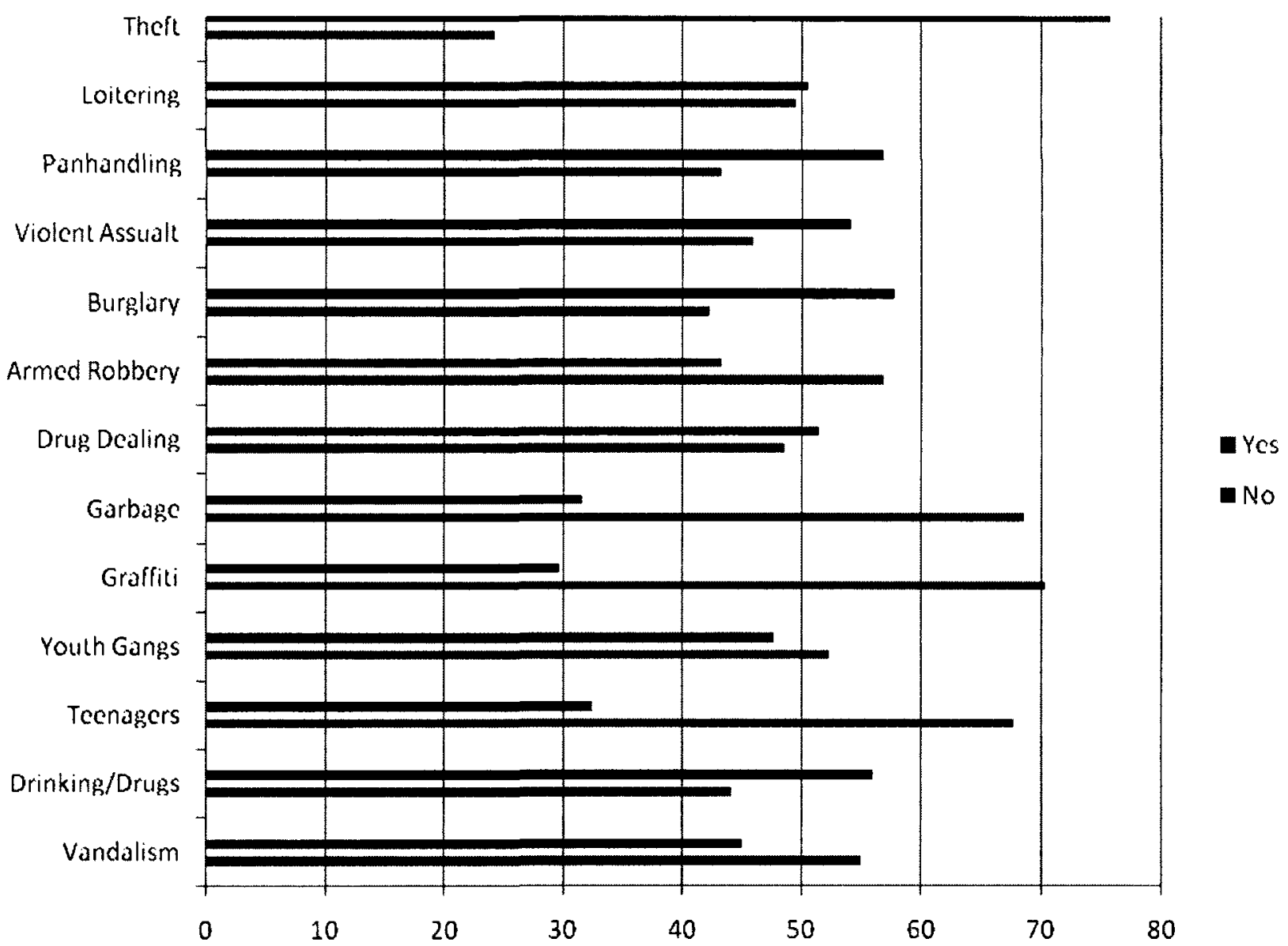


To measure the changes in the levels of crime, the merchants identified the changes in trends for each specific crime over the past year. The results allowed this thesis to identify which crimes are believed to be becoming more of a problem and which crimes are believed to be less of a problem (figure 3.3). There were five answers that could be chosen to answer the changes of crime (not a problem, not applicable, about the same, less of a problem, and more of a problem). The data results showed that the majority of issues were perceived to be about the same as they had been over the year. These include loitering ( 43 percent), violent assault ( 37 percent), drug dealing (41.3 percent), graffiti (35.2), youth gangs ( 30 percent), teenagers ( 35.8 percent), people drinking and using drugs ( 42.2 percent), and vandalism (41.1 percent). Theft and garbage were also considered to be about the same as the previous year; however, they were also equally considered more of a problem over the previous year; theft $(35.2$ percent versus 35.2 percent respectively) and garbage (34.3 percent versus 31.5 percent respectively). Panhandling was the only issue that 49.1 percent of all merchants felt had become more of an issue of the previous year. Moreover, burglary (31.8 percent) and armed robbery ( 42.2 percent) were not considered to be problems by the merchants. This is consistent with the levels of fear that were discussed previously. 
Figure 3.3 - Perceived Changes in Crime

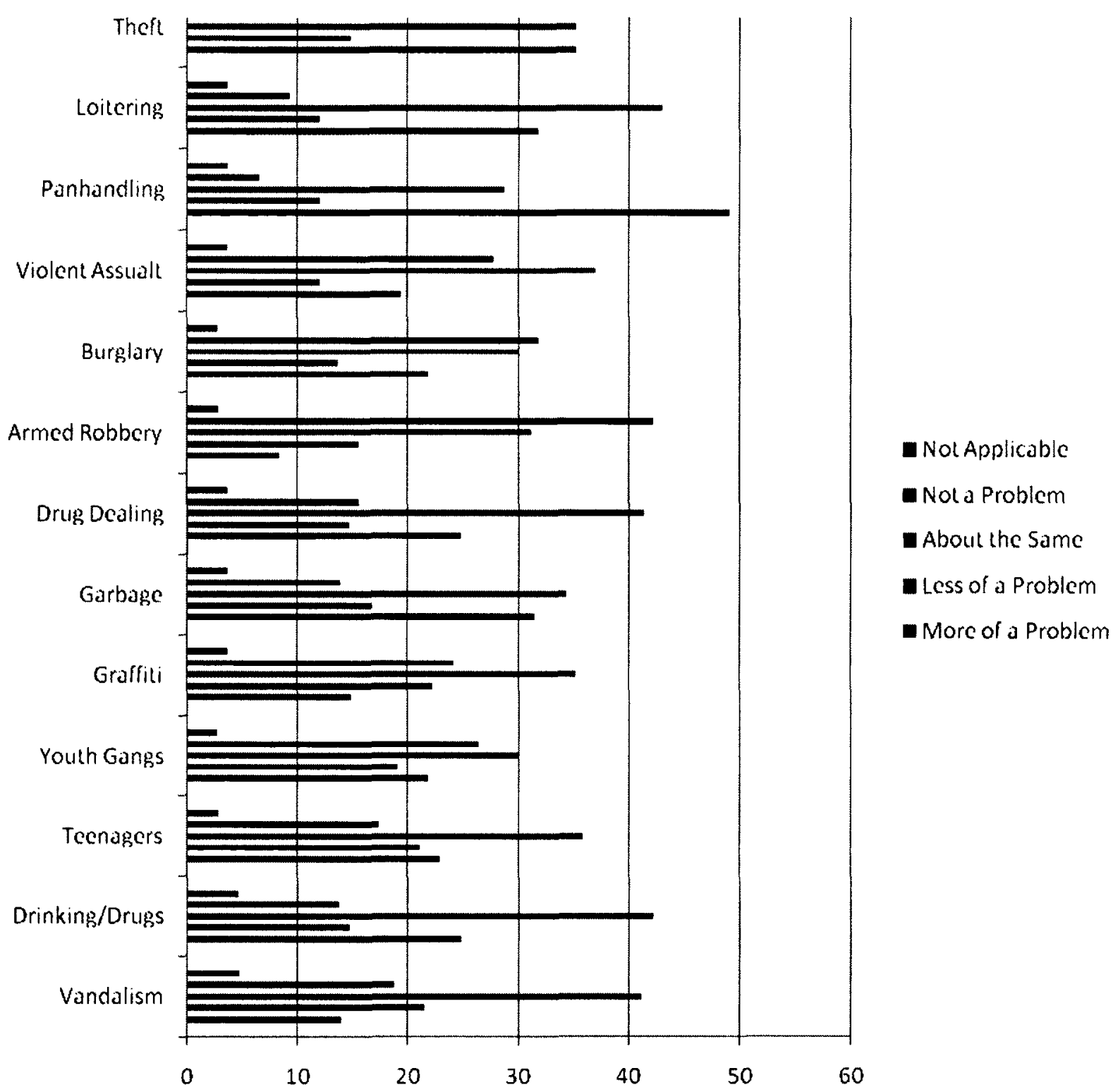

Overall crime in the area

The data results showed that the changes in the levels of crime were found to be consistent with the merchants' perception of crime in the entire DYBIA area. This lends support to the results that crime within the DYBIA area was about the same $(58.3$ 
percent) as evident by Figure 3.4. The remainder of the merchants felt that crime had either increased (18.5 percent) or decreased (23.1 percent) within the immediate proximity of their business. The increased levels of crime in the past year can be explained as a result of the garbage strike, garbage was listed as one of the crimes, and the increased levels of panhandlers.

Figure 3.4 - Perception of changes in crime over the past 12 months

\begin{tabular}{|cc|c|c|c|c|}
\hline & & Frequency & Percent & Valid Percent & $\begin{array}{c}\text { Cumulative } \\
\text { Percent }\end{array}$ \\
\hline Valid & Decreasing & 25 & 22.5 & 23.1 & 23.1 \\
& About the same & 63 & 56.8 & 58.3 & 81.5 \\
& Increasing & 20 & 18.0 & 18.5 & 100.0 \\
& Total & 108 & 97.3 & 100.0 & \\
\multirow{4}{*}{ Missing } & System & 3 & 2.7 & & \\
& Total & 111 & 100.0 & & \\
\hline
\end{tabular}

Furthermore, the merchant perception of crime (Figure 3.5) for all of the Downtown Yonge area showed that the perceived levels of crime in the area were either higher than it should be (45 percent), at a satisfactory level (35.1 percent), or at a low level (16.2 percent). The merchants in the DYBIA appear to feel that the Toronto Police Foot Patrol could be doing more to address crime in the area of their business as well as in the DYBIA as a whole. Specifically, 3.6 percent of merchants believed that crime in the Downtown Yonge area was very high and needed to be addressed immediately. 
(Figure 3.5) Perception of crime overall

\begin{tabular}{|c|c|c|c|c|c|}
\hline & & Frequency & Percent & Valid Percent & $\begin{array}{c}\text { Cumulative } \\
\text { Percent }\end{array}$ \\
\hline \multirow[t]{5}{*}{ Valid } & Low & 18 & 16.2 & 16.2 & 16.2 \\
\hline & At a satisfactory level & 39 & 35.1 & 35.1 & 51.4 \\
\hline & Higher than it should be & 50 & 45.0 & 45.0 & 96.4 \\
\hline & Very high & 4 & 3.6 & 3.6 & 100.0 \\
\hline & Total & 111 & 100.0 & 100.0 & \\
\hline
\end{tabular}

\section{Merchant perception of Police}

The merchants in the DYBIA were asked their perspective and opinion of the Toronto Police Service Foot Patrol's performance and methodology towards addressing crime and fear (Figure 3.6). The Toronto Police were considered by merchants to be doing a good job overall (44.1 percent) and in the category of friendliness ( 57.7 percent). They were also assessed as doing an average job in providing information to merchants (42.3 percent), following up on calls ( 36 percent), and in the prevention of crime (47.7 percent). The police are considered to be doing a poor job, according to figure 3.6, responding when they are called for an incident (39.6 percent). This means that when merchants are calling for police assistance concerning an issue they are having, police are slow to respond. When the police do arrive, they are considered by the merchants to be effective in performing their duties. The performance of their duties will have an immediate and direct effect on fear and the crime being committed. Similarly, the slow response of the police will have an increasing effect on levels of fear because merchants feel that if they call for assistance, the police will take a long time to arrive. 
Figure 3.6 - Merchant Perception of Police Performance

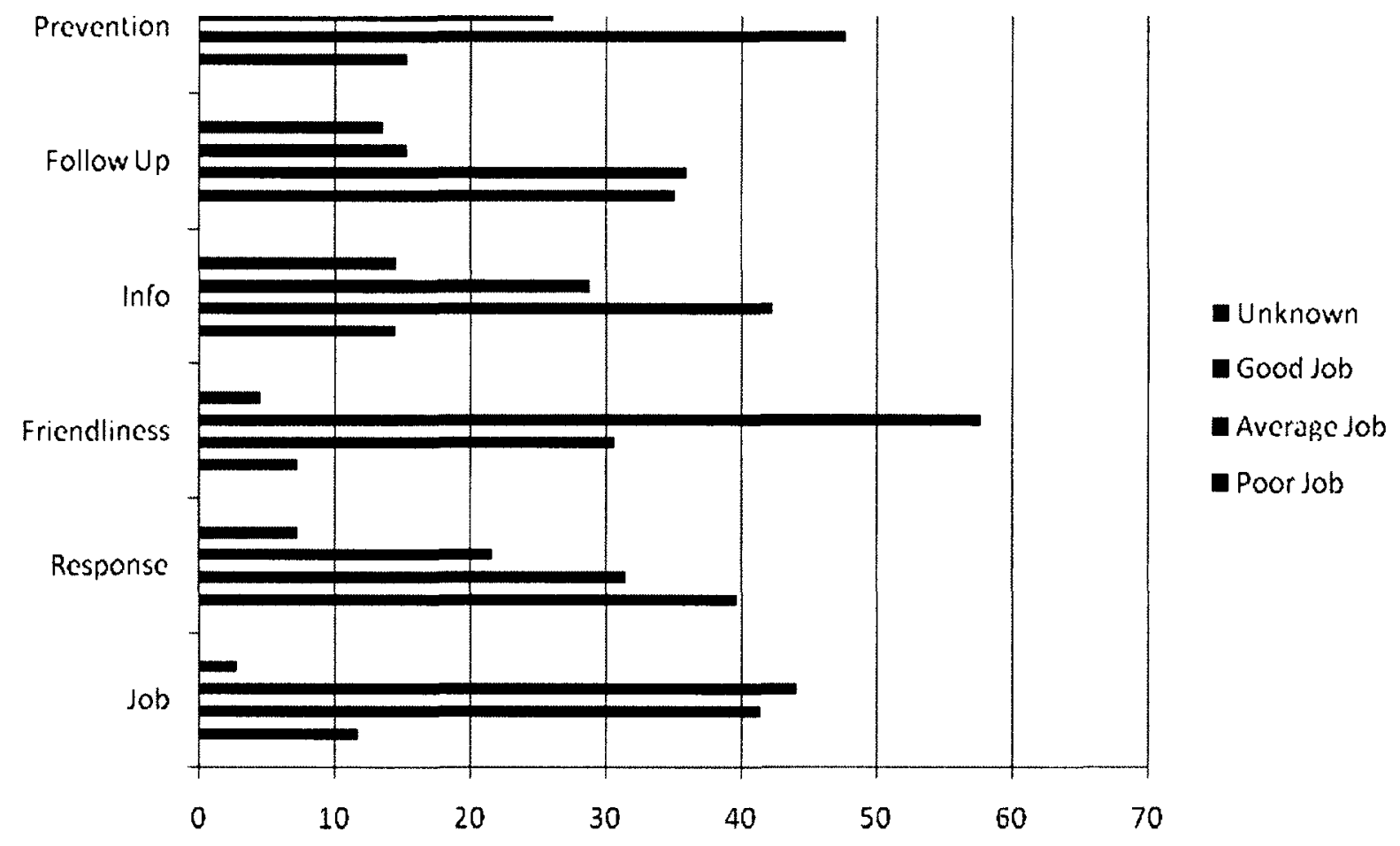

Moreover, merchants in the DYBIA were asked where Toronto Police Service should focus their attention in order to become more effective at addressing crime and alleviating fear. The consensus, according to figure 3.7, argues that the police need to focus their attention into all the areas discussed. More specifically, panhandlers (66.7 percent), drinkers (60.4 percent), and drug dealers (60.4 percent) were the three issues that the majority of merchants believed should be the focus of police attention. Loiterers (55.9 percent), drug users (43.2), and getting to know merchants (41.4) were the three issues that the majority of merchants believed needed the least amount of police attention. Managing loiterers, drug users, and getting to know the merchants are not considered, by 
merchants, to be immediate ways in which police can effectively address crime and their feelings of fear. Therefore, the merchants in the DYBIA believe that the police should focus upon panhandlers, drinkers, and drug dealers as the main focus of issues that relate to crime and fear within the area.

Figure 3.7 - Toronto Police Service Foot Patrol Focus

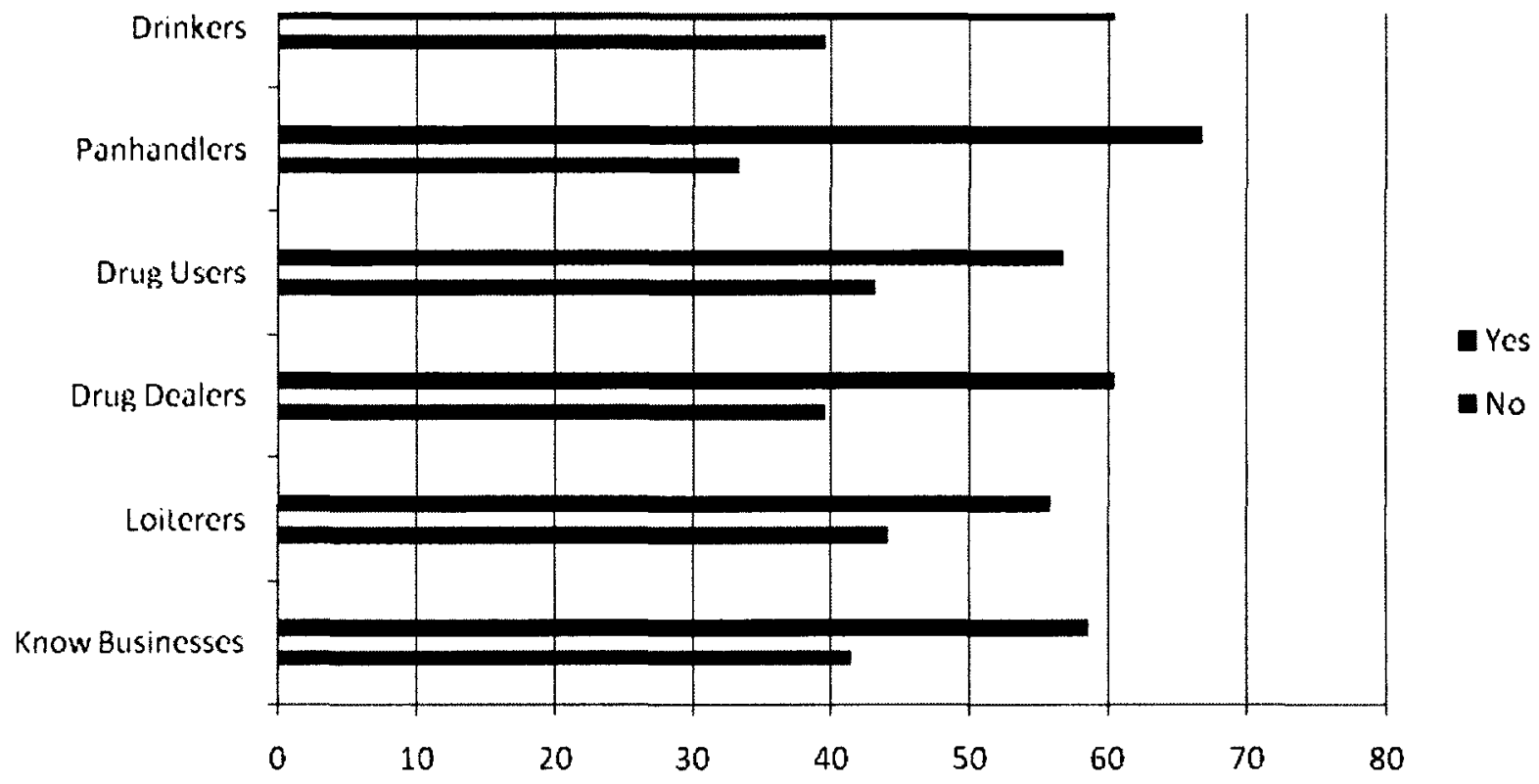

TPS Visibility and Interaction

Directly related to the levels of crime is the visibility and interaction of police with the DYBIA merchants and citizens. Figure 3.8 shows a significant difference between how often police visit a business versus how often they are seen in proximity to a business. The MSSS showed that 76.92 percent of businesses saw the police in proximity to their businesses 1-7 times per week. However, 40.4 percent of the businesses reported never being visited by Toronto Police Service foot patrols despite the frequency of visibility. Moreover, 41.28 percent of businesses responded that they were 
visited by TPS 1-7 times per week and 18.35 percent of businesses responded they were visited 8 or more times. These figures show that while the police are seen in proximity to business on a consistent basis, the police are not visiting each business as often as the merchants would like.

Figure 3.8 - Police Visibility and Visitation

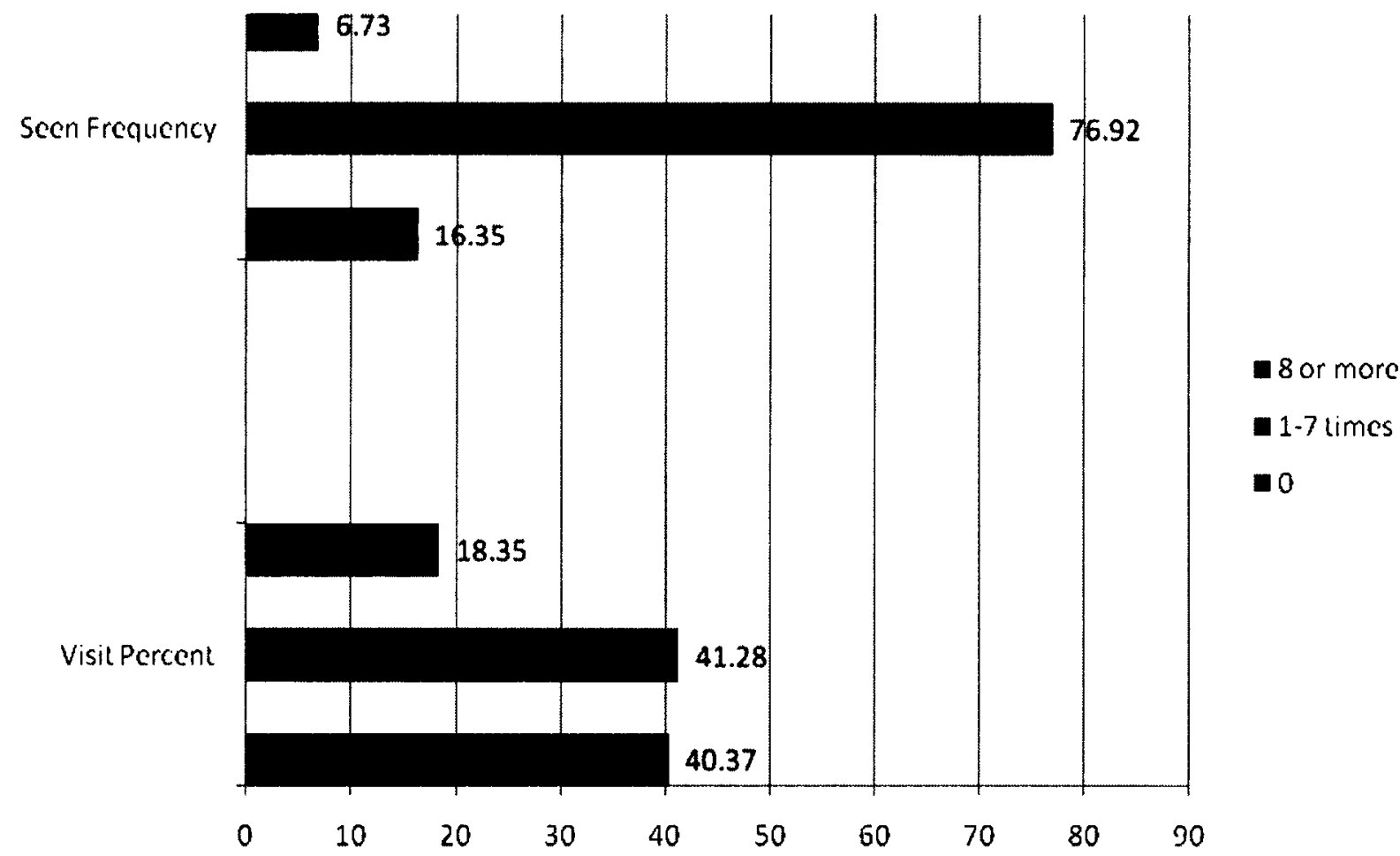

The conclusion that the Toronto Police Foot Patrol could directly impact the levels of crime and fear is furthered by figure 3.9. Figure 3.9 shows that 83.5 percent of merchants would like the police to visit their businesses regularly as they feel it would be beneficial to the prevention and/or detection of crime in the area. 
Figure 3.9 - Are TPS visits beneficial?

\begin{tabular}{|cc|c|c|c|c|}
\hline & & Frequency & Percent & Valid Percent & Cumulative Percent \\
\hline Valid & No & 6 & 5.4 & 5.5 & 5.5 \\
& Yes & 91 & 82.0 & 83.5 & 89.0 \\
& Not sure & 12 & 10.8 & 11.0 & 100.0 \\
\multicolumn{2}{|c|}{ Missing Total } & 109 & 98.2 & 100.0 & \\
\multicolumn{2}{|c|}{ Tystem } & 2 & 1.8 & & \\
\hline
\end{tabular}

\section{Personal Protection}

One of the primary reasons for the preference of the merchants for police to visit them regularly is that the merchants still view the Toronto Police as their primary method of safety and protection as opposed to private security (as seen in figure 3.10). 76.6 percent of merchants do not use any means of private security in the protection of their business as opposed to the 23.4 percent which do use private security in some form or another. As a result, the merchants' reliance upon the police is directly related to the desire for increased visibility and interaction as well as the reduction in the levels of crime and fear.

Figure 3.10 - Do you employ private security?

\begin{tabular}{|c|c|c|c|c|c|}
\hline & & Frequency & Percent & Valid Percent & Cumulative Percent \\
\hline Valid & No & 85 & 76.6 & 76.6 & 76.6 \\
\hline & Yes & 26 & 23.4 & 23.4 & 100.0 \\
\hline & Total & 111 & 100.0 & 100.0 & \\
\hline
\end{tabular}


Of the 23.4 percent of merchants who use private security, it is unclear what percentage use private security as an optional means of protection. 30.8 percent of the merchants use private security under mandatory conditions, as they are situated in a mall complex which provides security as part of the leasing agreement, and another 19.2 percent use private security for insurance purposes. Aside from these merchants, it is unclear what percentage of the merchants who use private security, to deter crime with increased presence (15.4 percent), to perform administrative functions for the owner ( 3.8 percent), extra safety and prevention ( 3.8 percent), increased crime ( 11.5 percent) and lack of police presence ( 7.7 percent), use private security as an optional means of protection.

Figure 3.11 - Reason for Employing Security

\begin{tabular}{|c|c|c|c|c|c|}
\hline & & Frequency & Percent & Valid Percent & $\begin{array}{l}\text { Cumulative } \\
\text { Percent }\end{array}$ \\
\hline \multirow[t]{9}{*}{ Valid } & $\begin{array}{l}\text { to perform admin function } \\
\text { for owner }\end{array}$ & 1 & .9 & 3.8 & 3.8 \\
\hline & extra safety/prevention & 1 & .9 & 3.8 & 7.7 \\
\hline & increase presence & 4 & 3.6 & 15.4 & 23.1 \\
\hline & $\begin{array}{l}\text { increased } \\
\text { crime/shootings/feel } \\
\text { threatened }\end{array}$ & 3 & 2.7 & 11.5 & 34.6 \\
\hline & $\begin{array}{l}\text { Police apathy/lack of } \\
\text { police }\end{array}$ & 2 & 1.8 & 7.7 & 42.3 \\
\hline & Insurance purposes & 5 & 4.5 & 19.2 & 61.5 \\
\hline & Mall & 8 & 7.2 & 30.8 & 92.3 \\
\hline & no reason & 2 & 1.8 & 7.7 & 100.0 \\
\hline & Total & 26 & 23.4 & 100.0 & \\
\hline Missing & System & 85 & 76.6 & & \\
\hline Total & & 111 & 100.0 & & \\
\hline
\end{tabular}


It must also be recognized that 50 percent of the merchants who used private policing believed that they were more effective than Toronto Police (according to Figure 3.12). Only 9.1 percent believed Toronto Police to be more effective than private security, 18.2 percent felt that private security was only quicker to respond to calls than Toronto Police and the merchants who employed private policing believed they were more effective than police in addressing crime. One possible reason for the higher levels of effectiveness is the proximity of the private security officers to the businesses (specifically mall based security).

Figure 3.12 - Is Private Security More Effective Than TPS

\begin{tabular}{|ll|r|r|r|r|}
\hline & & & & \multicolumn{2}{c|}{$\begin{array}{c}\text { Cumulative } \\
\text { Percent }\end{array}$} \\
\hline Valid & No & 2 & 1.8 & 9.1 & 9.1 \\
& They are about the same & 3 & 2.7 & 13.6 & 22.7 \\
& Yes & 11 & 9.9 & 50.0 & 72.7 \\
& More effective & 2 & 1.8 & 9.1 & 81.8 \\
& Easier or quicker & 4 & 3.6 & 18.2 & 100.0 \\
& Total & 22 & 19.8 & 100.0 & \\
Missing & System & 89 & 80.2 & & \\
Total & & 111 & 100.0 & & \\
\hline
\end{tabular}

As another form of personal protection, merchants were also asked their opinion on the effectiveness of using Trespass to Property Act Forms - forms which state that an individual is not legally allowed to be present in a specified area; failure to abide by the document is punishable by arrest and fine by police for trespassing - which allow the merchants to control who is allowed to be on their property and who is not allowed, only 31.5 percent (According to Figure 3.13) actually completed the TPA. 60.4 percent of 
merchants stated that they had not filled out a TPA form (figure 3.13) and only 30.4 percent of merchants (according to Figure 3.14) would be willing to fill out a TPA form. The merchants who had not filled out a TPA either unwillingly (refusing to fill one out) or due to ignorance of the document, were willing to use a TPA form to control who is allowed in their business after having been better informed of what a TPA is. Conversely, 24.3 percent of merchants were still unwilling to fill out a TPA form after having been better informed of TPAs. According to figure 3.14, the main reasons for refusal were recorded for not filling out a TPA included applicability and necessity. 73.9 percent of merchants believed that a TPA would not apply to them and 10.8 percent believe that there is no need for them to fill out a TPA. Some merchants would see the use of TPA forms as a loss of business. This results from a belief that if an individual is a problem this time, they are not necessarily going to be a problem next time and could be potential customers. Therefore, merchants are not willing to ban potential customers and potential sources of profit. TPA forms only guarantee the loss of profit from their viewpoint.

Figure 3.13 - Have You Completed the TPA Form? Will you Complete TPA Now

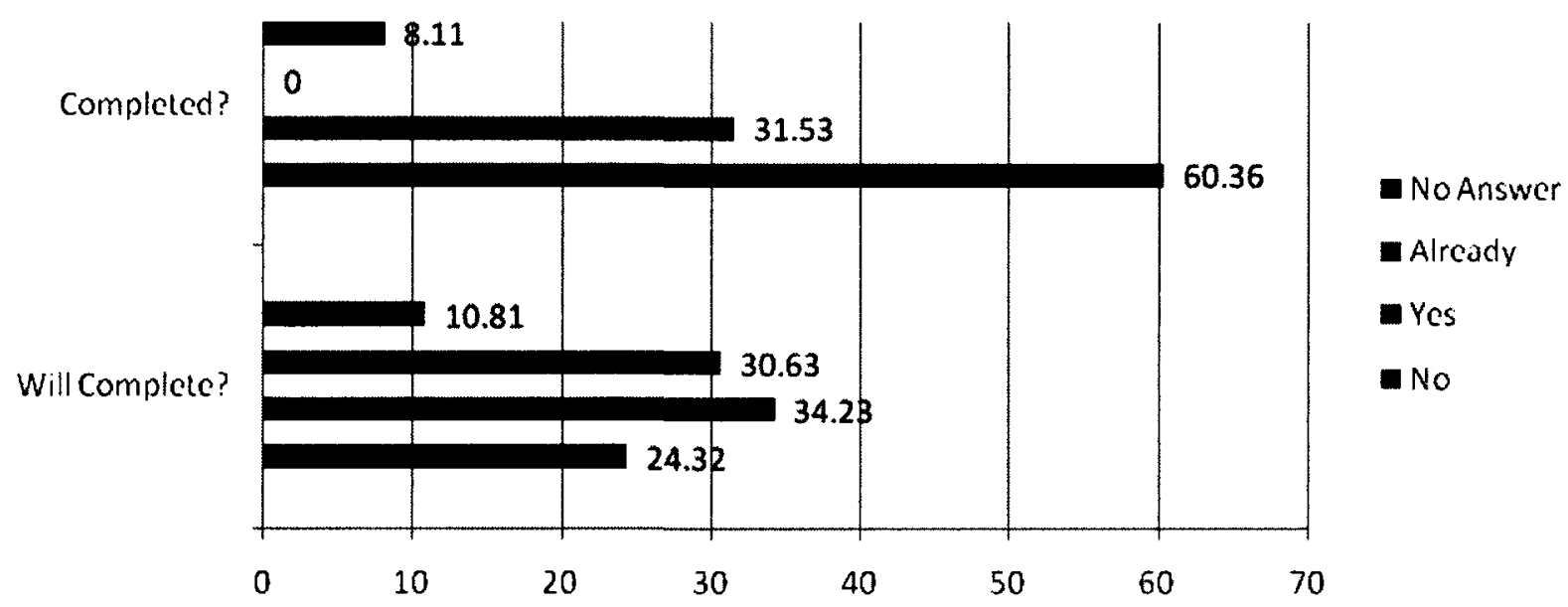


Figure 3.14 - Reason For Not Filling Out TPA Form

\begin{tabular}{|l|r|r|r|r|}
\hline & Frequency & Percent & Valid Percent & $\begin{array}{c}\text { Cumulative } \\
\text { Percent }\end{array}$ \\
\hline Valid undecided & 1 & .9 & .9 & .9 \\
Wanted to read it first & 4 & 3.6 & 3.6 & 4.5 \\
Won't help & 6 & 5.4 & 5.4 & 9.9 \\
Don't know what it is & 1 & .9 & .9 & 10.8 \\
For owner/corporate to fill & 4 & 3.6 & 3.6 & 14.4 \\
out & & & & \\
Don't need it & 12 & 10.8 & 10.8 & 25.2 \\
not applicable/would not & 82 & 73.9 & 73.9 & 99.1 \\
apply & 1 & .9 & .9 & 100.0 \\
No opportunity to issue one & 111 & 100.0 & 100.0 & \\
Total & & & & \\
\hline
\end{tabular}

\section{Statistical Significance:}

The statistical significance has been calculated by separating police visitation and visibility into separate variables and broken down into three categories to be crosstabulated. The three categories are: zero times a week, one to five times a week, and 6 or more times a week. After each comparison the statistical significance will be given to show the relationship. The purpose of the significance testing is to show the relationship between police efforts and the measurable effects that result from those effects (see appendix $\mathrm{C}$ for more information). In essence, the significance testing is able to measure whether police visitation is more effective in addressing one crime or source of fear versus police presence. The significance testing will also be calculated in the next 
chapter for both past and present data to see if there exists a measurable relationship over a period of time that may not be as visible when viewing only a single set of data.

The significance testing was calculated for ten (10) primary variables that were determined to be the primary sources of fear and risk, and a general census of the data. These variables are as follows: Fear of burglary; fear of armed robbery; fear of theft; fear associated with walking alone after dark; fear associated with walking to the car after dark off of Yonge Street; the fear of serving unknown patrons after dark, the fear of walking past strangers after dark; fear of working alone after dark; overall crime in the area; and finally the changes in crime in the past twelve (12) months (see figures 3.15 , $3.16,3.17$, and 3.18).

57.7 percent of merchants felt that burglary was a major concern of theirs when they themselves were not present at their business. Police visitation was calculated as being highly statistically significant in regards to the fear of burglary $\left(X^{2}=0.142, d f=2\right.$, $\mathrm{p}<.001$ ). Similarly, police presence was calculated as being statistically significant in the reduction of the fear of burglary $\left(X^{2}=0.180, \mathrm{df}=2, \mathrm{p}<.01\right)$. However, as the correlation data shows, visitation is calculated as being more significant with regards to the reduction of fear as opposed to presence. Therefore, while the data is significant in both regards, the visitation is calculated as the more effective means.

Conversely, the data shows that police presence was more significant in influencing levels of fear associated with armed robbery $\left(X^{2}=1.844, \mathrm{df}=2, \mathrm{p}<.01\right)$ than police visitation $\left(X^{2}=7.248, d f=2, p>.05\right)$. This means while merchants did not feel that armed robbery was an issue of concern for them (as evident by figure 3.2), police presence was calculated as being more effective in addressing the levels of fear. 
Moreover, police visitation was considered unnecessary by merchants in order to maintain a low level of fear associated with armed robbery.

Unfortunately, police visitation was measured as having a minimal effect on the levels of fear associated with theft $\left(\mathrm{X}^{2}=6.453, \mathrm{df}=2, \mathrm{p}<.05\right)$. This means that as police visited a business along Yonge Street, the fear associated with theft was not impacted at all. Similarly, police presence in the area was measured as having minimal effect on the levels of fear associated with theft $\left(X^{2}=2.394, d f=2, p<.05\right)$. This shows that neither police presence nor visitation are effective deterrents of crime and is therefore of low significance.

As can be seen in the previous three variables, the significance of the data shows that either visitation or visibility can be more or less effective with regards to merchants' perceptions, and in some cases have no measurable effect at all. However, the significance testing for the other variables that were mentioned shows that with the exception of the changes in crime in the past 12 months and working alone after dark, Toronto Police visibility seems to be of greater influence upon the levels of fear (see figure 3.18). Toronto police visibility was measured to be effective at addressing the overall crime $\left(X^{2}=2.599, \mathrm{df}=6, \mathrm{p}<.01\right)$ most significantly versus police visitation $\left(\mathrm{X}^{2}\right.$ $=11.887, \mathrm{df}=6, \mathrm{p}<.05)$. Which means that while individual fears, such as walking alone after dark $\left(X^{2}=7.893, d f=8, p<.05\right)$, walking to the car after dark $\left(X^{2}=11.319\right.$, $\mathrm{df}=8, \mathrm{p}<.05)$, serving unknown customers after dark $\left(\mathrm{X}^{2}=15.388, \mathrm{df}=8, \mathrm{p}<.05\right)$, and walking past strangers $\left(X^{2}=9.278, \mathrm{df}=8, \mathrm{p}<.05\right)$, were affected significantly by police foot patrol and overall crime was impacted most significantly. This is indicative of increased feelings of safety and reduced levels of risk. Furthermore, police foot patrol 
visibility was significantly influencing the levels of fear within the area without specifically targeting one problem or another. The data shows that police visibility creates a blanket effect upon an area whereby crime in general is seen to be reduced and less feared. Therefore, the correlative data shows that as police visibility increases, fear of crime becomes less problematic.

Moreover, police visitation is not seen as effective in the reduction of fear in the majority of variables. When comparatively measured, walking alone after dark $\left(\mathrm{X}^{2}=\right.$ $16.185, \mathrm{df}=8, \mathrm{p}<.05)$, walking to the car after dark $\left(X^{2}=20.424, \mathrm{df}=8, \mathrm{p}<.05\right)$, serving unknown customers after dark $\left(\mathrm{X}^{2}=16.511, \mathrm{df}=8, \mathrm{p}<.05\right)$ and walking past strangers $\left(X^{2}=14.456, d f=8, p<.05\right)$, were still significantly affected by police visitation. However, the degree to which they were measured as being significantly impacted is not as dominant as it is with working alone after dark. Working alone after dark $\left(X^{2}=6.244, d f=8, p<.001\right)$ was measured as being impacted more by police visitation versus police foot patrol visibility $\left(X^{2}=5.246, d f=8, p<.05\right)$. Rather, the data shows that police foot patrol visitation had a measurable influence upon the increased levels of safety versus police visibility. This means that while merchants were working in their business alone after dark, they felt safer if the police visited their store creating an appearance that they are on familiar terms with the police officers. This contrasts with the other crimes, where police presence alone was enough to impact the feelings of safety and fear.

However, in the terms of the changes in the levels of crimes in the past 12 months, both police visitation $\left(X^{2}=9.692, d f=4, p>.05\right)$ and police visibility $\left(X^{2}=\right.$ 3.362, $\mathrm{df}=4, \mathrm{p}>.05$ ) were measured as being statistically ineffectual (figure 3.16). This 
means that while police visibility and police visitation are reducing the levels of fear within the area, they are not being as effective in reducing the levels of crime. One answer for this is the already reduced levels of crime in the area that may have resulted from the previous years of patrol. In the next chapter, the figures discussed in this chapter will be compared to the data gathered from the previous studies in order to find the relationship between the changes in the data.

(Figure 3.15) TPS Voluntarily Visited versus TPS Seen Around Business (0 Visits, 1-5 Visits, 6 or More)

\begin{tabular}{|c|c|c|c|}
\hline $\begin{array}{c}\text { Comparative } \\
\text { Variable }\end{array}$ & Visit/Visibility & Chi Square $\left(\mathrm{X}^{\wedge} 2\right)$ & Df \\
\hline Fear Burglary & Visit & $0.142^{* * *}$ & 2 \\
& Visibility & $0.180^{* *}$ & 2 \\
\hline Fear Armed Robbery & Visit & $7.248^{*}$ & 2 \\
& Visibility & $1.844^{* *}$ & 2 \\
\hline Fear Theft & Visit & $6.453^{*}$ & 2 \\
& Visibility & $2.394^{*}$ & 2 \\
\hline \multicolumn{2}{|l}{} \\
& ${ }^{* * *}-p<.001 ;{ }^{* *}-p<.01 ;{ }^{*}-p<.05$
\end{tabular}

(Figure 3.16) TPS Voluntarily Visited versus TPS Seen Around Business (0 Visits, 1-5 Visits, 6 or More)

\begin{tabular}{|c|c|c|c|}
\hline $\begin{array}{c}\text { Comparative } \\
\text { Variable }\end{array}$ & Visit/Visibility & Chi Square $\left(\mathrm{X}^{\wedge} 2\right)$ & Df \\
\hline $\begin{array}{c}\text { Changes in Crime } \\
\text { 12 Months }\end{array}$ & Visit & 9.692 & 4 \\
\hline \multicolumn{2}{|l|}{ Visibility } & 3.362 & 4 \\
\hline
\end{tabular}

(Figure 3.17) TPS Voluntarily Visited versus TPS Seen Around Business (0 Visits, 1-5 Visits, 6 or More)

\begin{tabular}{|c|c|c|c|}
\hline $\begin{array}{c}\text { Comparative } \\
\text { Variable }\end{array}$ & Visit/Visibility & Chi Square $\left(\mathrm{X}^{\wedge} 2\right)$ & Df \\
\hline Overall Crime & Visit & $11.887^{*}$ & 6 \\
& Visibility & $2.569^{* *}$ & 6 \\
\hline \multicolumn{2}{|c|}{} \\
\hline
\end{tabular}


(Figure 3.18) TPS Voluntarily Visited versus TPS Seen Around Business (0 Visits, 1-5 Visits, 6 or More)

\begin{tabular}{|c|c|c|c|}
\hline $\begin{array}{c}\text { Comparative } \\
\text { Variable }\end{array}$ & Visit/Visibility & Chi Square $\left(\mathrm{X}^{\wedge} 2\right)$ & $\overrightarrow{\mathrm{Df}}$ \\
\hline $\begin{array}{l}\text { Walk Alone After } \\
\text { Dark }\end{array}$ & $\begin{array}{c}\text { Visit } \\
\text { Visibility }\end{array}$ & $\begin{array}{l}16.185^{*} \\
7.893^{* *}\end{array}$ & $\begin{array}{l}8 \\
8\end{array}$ \\
\hline $\begin{array}{c}\text { Walk to Car After } \\
\text { Dark }\end{array}$ & $\begin{array}{c}\text { Visit } \\
\text { Visibility }\end{array}$ & $\begin{array}{c}20.424^{*} \\
11.319^{* *}\end{array}$ & $\begin{array}{l}8 \\
8\end{array}$ \\
\hline $\begin{array}{c}\text { Serving Unknowns } \\
\text { after Dark }\end{array}$ & $\begin{array}{c}\text { Visit } \\
\text { Visibility }\end{array}$ & $\begin{array}{c}16.511^{*} \\
15.388^{* *}\end{array}$ & $\begin{array}{l}8 \\
8\end{array}$ \\
\hline $\begin{array}{c}\text { Walking Past } \\
\text { strangers }\end{array}$ & $\begin{array}{c}\text { Visit } \\
\text { Visibility }\end{array}$ & $\begin{array}{l}14.456^{*} \\
9.278^{* *}\end{array}$ & $\begin{array}{l}8 \\
8\end{array}$ \\
\hline $\begin{array}{l}\text { Working Alone } \\
\text { After Dark }\end{array}$ & $\begin{array}{c}\text { Visit } \\
\text { Visibility }\end{array}$ & $\begin{array}{l}6.244^{* * *} \\
5.246^{*}\end{array}$ & $\begin{array}{l}8 \\
8\end{array}$ \\
\hline
\end{tabular}




\section{Chapter 4-Comprehensive Analysis}

The previous chapter discussed the 2009 data results of the Merchant Security

Satisfaction Survey, which measured the levels of fear, crime, response to policing agencies activities, safety and security. Based on the same questions, this chapter compares the results of both the 2005 and 2007 research studies to the 2009 data results. Particularly, this chapter will focus on the results in regards to fear of crime as a means to further emphasize the effectiveness of foot patrol within the DYBIA. Along with the information provided in the previous chapter, the discussion on data results provides the foundation for the discussion section which follows.

Perception of Safety and Levels of Fear

On the whole, the 2009 data results showed that merchants felt reasonably safe in every situation that was asked of them. This current result is different than that of the 2005's data outcomes, and that of 2007 also, as established in figure 4.1. In 2009 , the only safety issues indicated were being alone in their business after dark or when walking to a parking lot located off of Yonge Street. However, in 2005, merchants felt very unsafe when they were serving unknown patrons, and walking to public transit. In fact, waiting for a ride outside of their business or riding public transit were the only times in which merchants felt any sense of safety. In 2007 , the merchant's perception of safety improved significantly as travelling off of Yonge Street was the primary source of diminished safety for them. This data-set connotes that the foot patrol program, which was initiated in 2005 , increased the perception of safety among Yonge St. merchants significantly. This result can also be attributed to the visibility of pedestrian traffic, 
presence of Toronto Police Foot Patrol, and DYBIA's environmental design. All of these sources influence feelings of safety by merchants.

Figure 4.1 - Merchant Perception of Safety

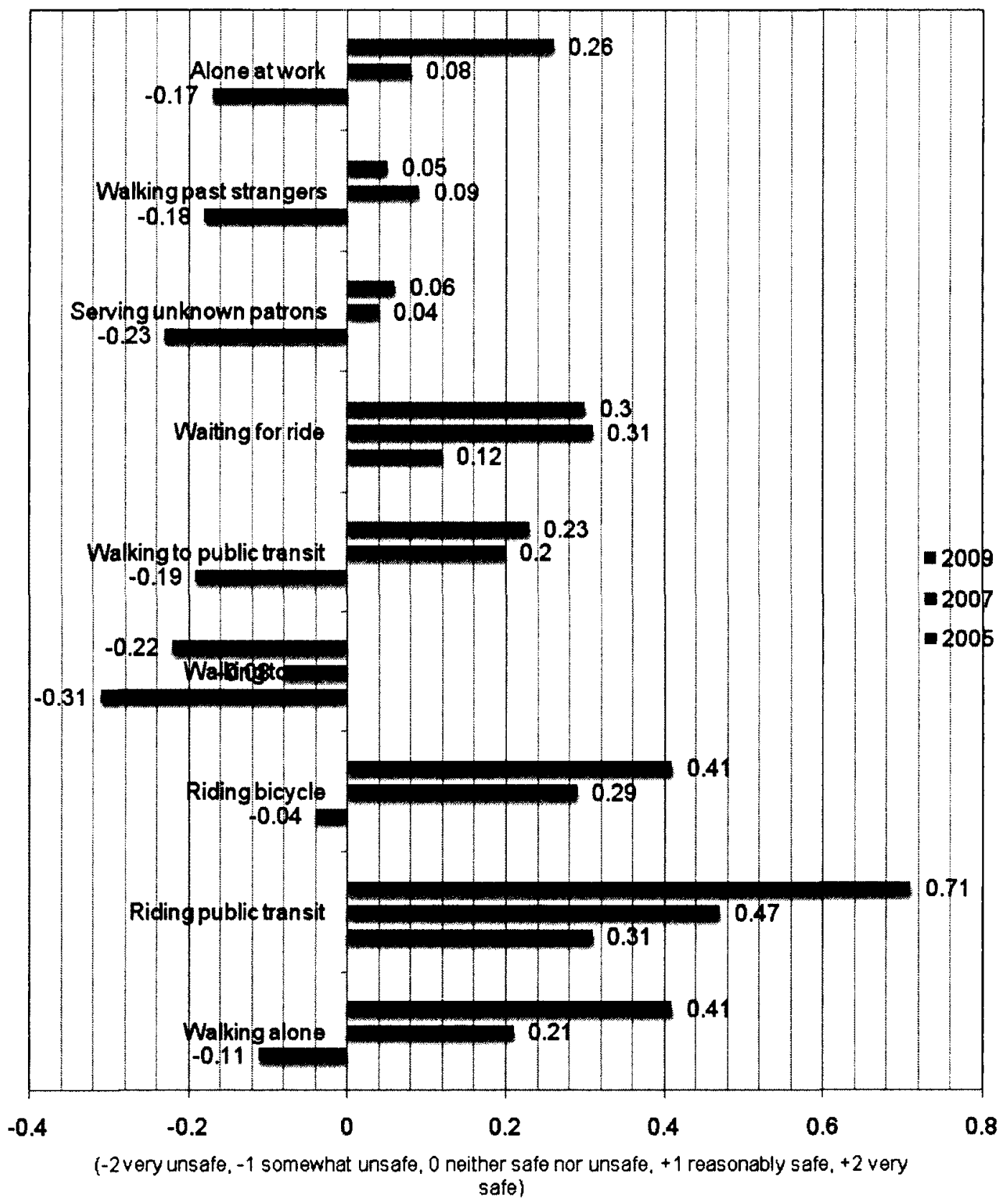

The increased perception of safety can also be measured through identifying the sources of fear that merchants experienced. Merchants in the 2009 study expressed their greatest fear came from the threat of theft, loitering, panhandling, violent assault, 
burglary, drug dealing, drinking and drug use (Figure 4.2). In particular, theft (76 percent), burglary ( 58 percent), and panhandling ( 57 percent) were the three sources of fear that most concerned merchants. In 2005 , merchants identified armed robbery ( 74 percent), loitering ( 70 percent), and drinking in public ( 70 percent) as the primary sources of fear for their business. In 2007 , the data results mapped in figure 4.2 show that merchants within the DYBIA identified theft (81 percent), armed robbery (75 percent), drug dealing (71 percent), violent assault (71 percent), and loitering ( 71 percent) as the leading sources of fear; in 2005, merchants were concerned with drinking in public and loitering of undesirables, theft and armed robbery. The focus of merchants in 2005 was on what could impact their business, as opposed to their 2009 focus on issues confronting the area around their business.

In 2007, two years after the start of the foot patrol program, and approaching the end of the BIA sponsored foot patrol program, the sources of fear for merchants shifted. While merchants were still concerned with the immediate threats to their business, such as theft or armed robbery, the concerns regarding their business zone were also becoming more prevalent; examples of these concerns include drug dealing, violent assault, and loitering. The latter of which has an effect on both the area and concern of the business, as mentioned above. However, as an area based concern, loitering has more importance to merchants than incidences of drug dealing and violent assault. The movement of marginalized citizens to the area is perceived to increase the levels of drug dealing and violent assault. As such, the recognition of these three sources of fear illustrates the shift from a private mentality, viewing their business as all that matters, to a more community oriented mentality. The data in 2009 supports this community-focused mentality. 
Merchants' community-focused perception in conjunction with a police foot patrol program, reduced the perceived levels of fear. This is evident in the levels of fear associated panhandling, theft, and burglary. Panhandling, theft, and burglary were perceived to be associated with undesirables. Theft and burglary will always be concerns for businesses but not directly related to safety issues. Panhandling, as discussed in chapter three, can be a negative deterrent to customers desiring to enter a store, and can also raise concerns for personal safety. The transitions from personal focus (i.e. any individual inside a merchants' store) to community focus (any individual in the area of the merchants' store) are further supported by the data above on perception of safety. The fears that merchants identified in 2005, 2007, and 2009 show the same trends as the perception of safety in the corresponding years. 


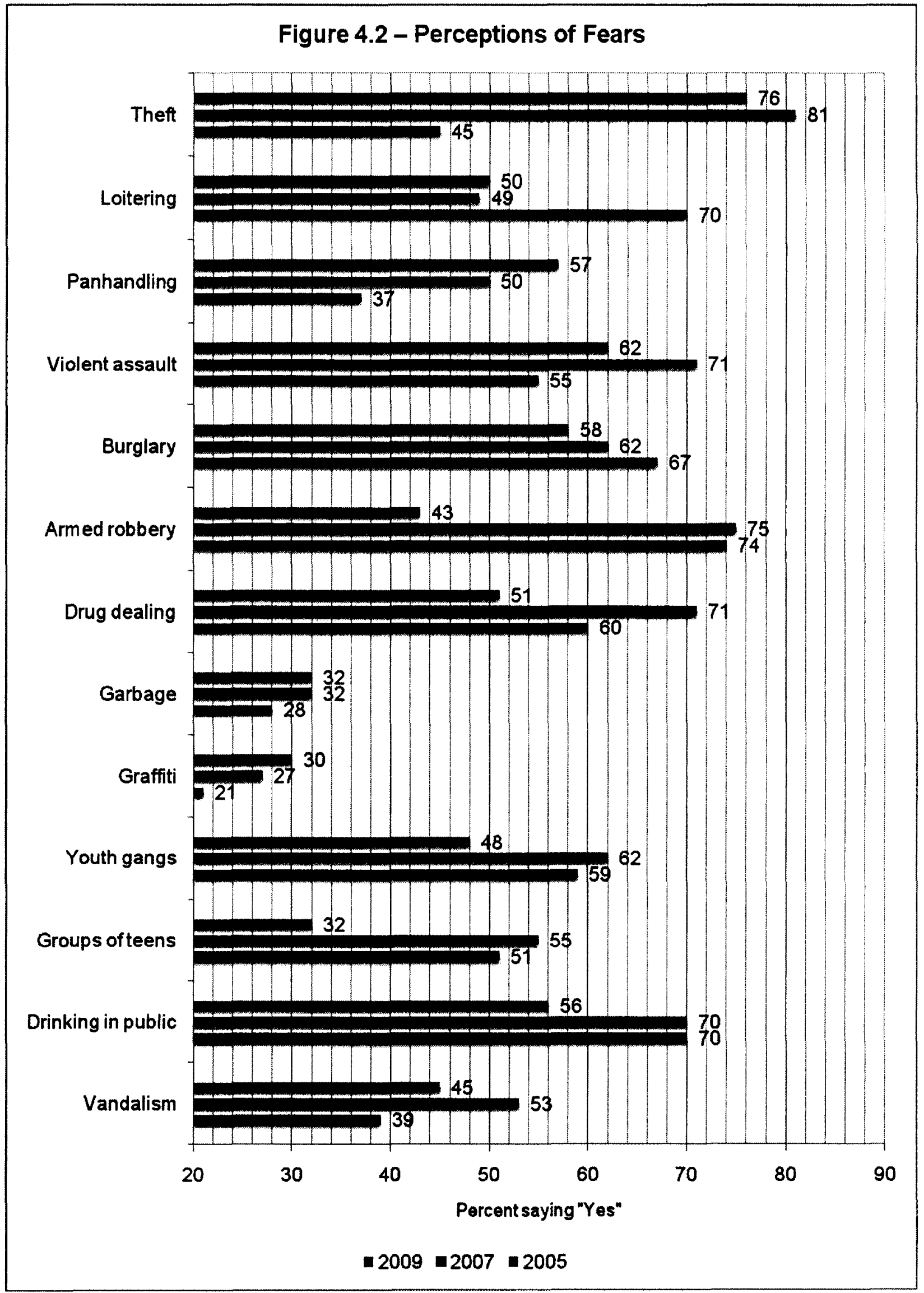


These trends are also evident in the data plotting changes in the levels of crime for 2005,2007 , and 2009. In 2005 , merchants identified rises in levels of crime between 10.1 percent and 36.5 percent, while the changes in the levels of crime ranged from 16.5 percent to 43.8 percent in 2007 . In 2009 , the data results showed that the levels of crime for the majority of issues were perceived to have remained about the same as in 2007, according to figure 4.3 .

In 2005, merchants were more concerned with the issues that affected or influenced their business only, once the focus was upon community issues in 2007 , the perception of crime also rose. Merchant trust in police also increased and the merchants felt if they reported crime it would be dealt with by police. In 2009 , four years after the beginning of the foot patrol program and community based interaction, the levels of perceived crime dropped significantly. The increase in crime was between 8.3 percent and 49.1 percent; 49.1 percent representing the rise in panhandling. 
Figure 4.3 - Perceived Changes in Crime: 'More of problem'

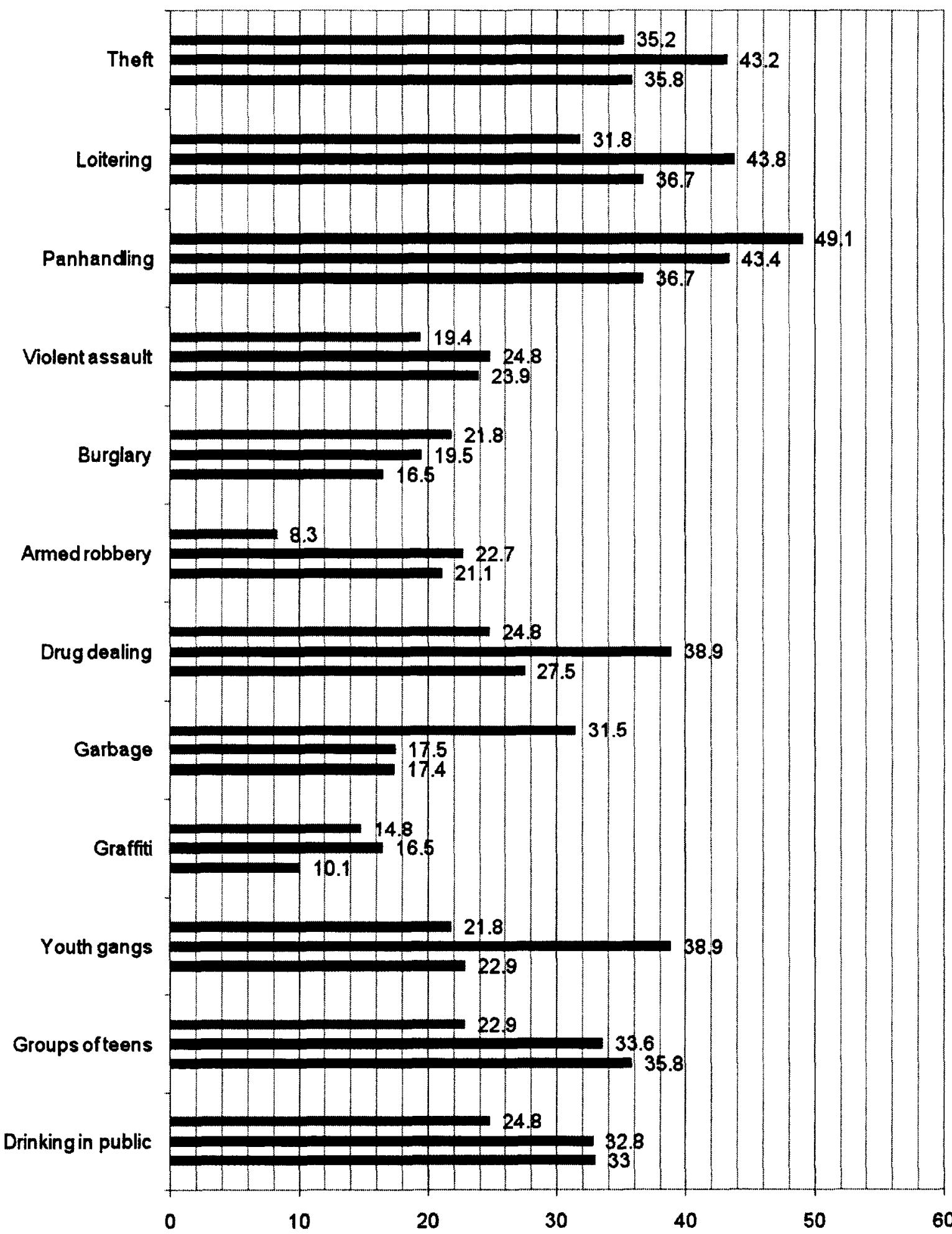

Respondents answering 'less of a problem', 'about the same' and 'not a problem' not shown 


\section{Overall Crime in the Area}

The changes in the perceptions of crime and perceptions of fear are ultimately reflected in the perceived changes of crime in the overall area; figure 4.4 shows the perceived changes in crime in the overall area. In 2005, 14.7 percent of merchants felt that crime in the overall area was very high and 61.5 percent of merchants felt that crime was higher than it should be. In 2007, two years after the start of the foot patrol program, the percentage of merchants who felt crime was very high fell 3.1 percent to 11.6 percent. The number of merchants who felt that crime was higher than it should be dropped by 10.1 percent to 51.4 percent. While perceptions of crime rates were high, merchants are of the opinion that the levels of crime in the overall DYBIA area were dropping. In 2009 , the perceived levels of crime continued to drop as the percentage of merchants who felt crime was very high dropped by 8 percent to a total of 3.6 percent. The percentage of merchants who felt that crime was higher than it should be also dropped by 6.4 percent to a total of 45 percent. The other statistically significant factor in the data is the percentage of merchants' perceptions of crime levels at a satisfactory and low level.

From 2005 to 2009, the satisfaction of merchants towards police's ability to address the levels of crime rose from 18.3 percent to 35.1 percent, respectively. This rise connotes that the Foot Patrol program and the community initiatives by the Downtown Yonge Business Improvement Area organization had a positive effect on their perceived level of safety and security. This is further reflected by the rise in the percentage of merchants who felt that crime was low, from 5.5 percent in 2005 to 16.2 percent in 2009 . This data reveals that the initiatives to address fear of crime in the DYBIA between 2005 
and 2009 have resulted in merchants expressing greater feelings of safety and security within their businesses and while travelling along Yonge Street.

Figure 4.4 - Perception of changes in crime over the past 12 months

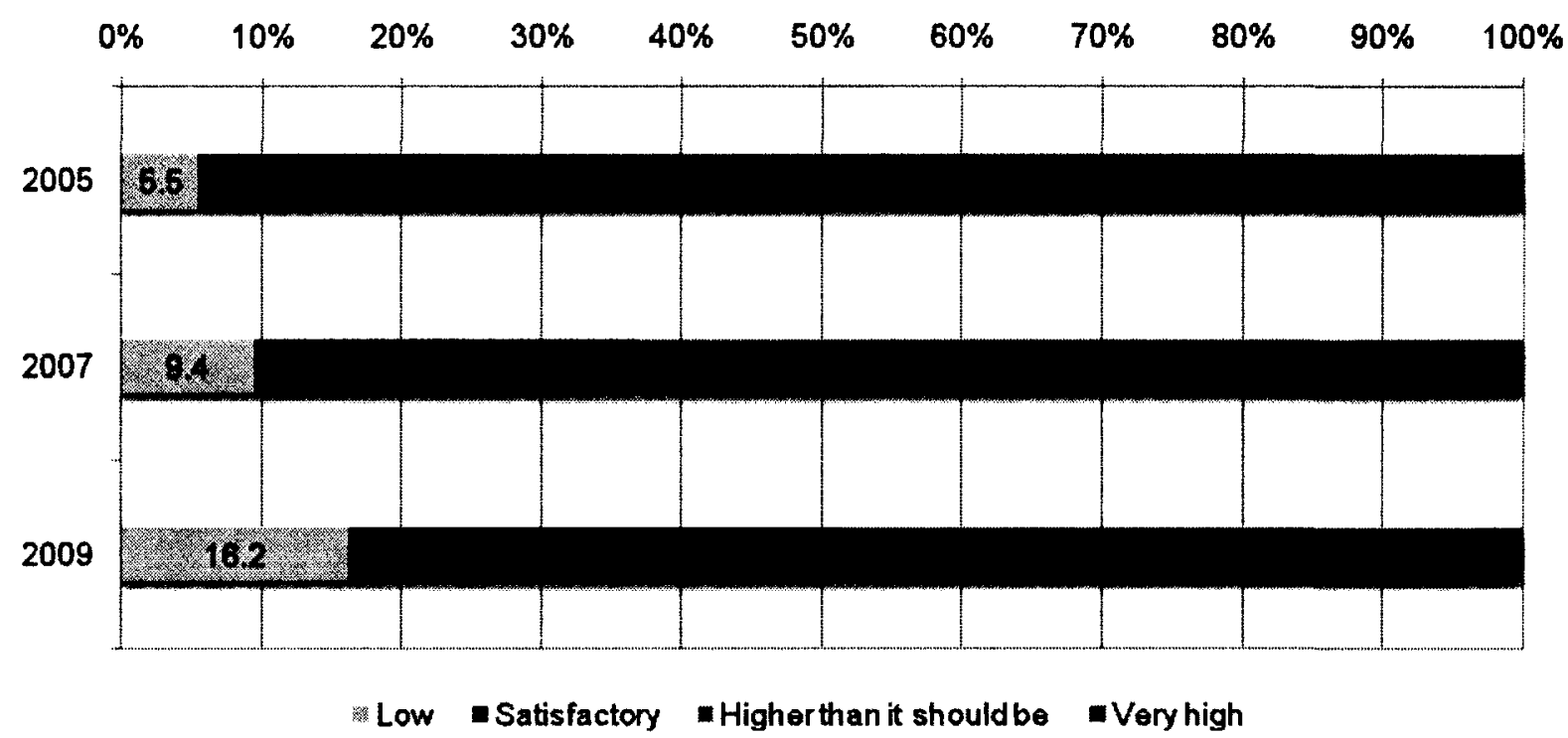

\section{Merchant perception of Police}

Perceptions of police effectiveness, which have been used to explain perceived changes in crime and fear, have also changed along with the perceptions of fear of crime. As seen in figure 4.5, merchants' perception of police effectiveness in preventing crime changed from 2005 to 2009 , dropping from 29.4 percent to 17.2 percent. As well, the percentage of merchants who felt that police were doing a good job at preventing crime significantly increased from 10.6 percent in 2005 to 29.3 percent in 2009 . This means that overall, the perceptions of the effectiveness and capabilities of the Toronto Police has increased and, at least in part, some of that increase was due to Police Foot Patrol. The positive rise in police effectiveness was found to be influenced by the Police Foot 
Patrol's efforts to provide information on crime prevention to the merchants, their friendliness, and perceived ability of the Police to enforce the law.

Merchants' perception of the Police providing information on how to protect themselves from crime improved from 15.9 percent in 2005 to 33.3 percent in 2009. This indicates that Police are becoming more involved with the merchants in the protection of their businesses. Moreover, this developing relationship between merchants and police is also indicated by the rise in the perception of police friendliness. In $2005,47.9$ percent of merchants felt that the police were friendly or more approachable. This percentage rose to 60.4 percent in 2009 , which indicates that the increased levels of interaction were having an impact on the merchants' perceptions in regards to the effectiveness of police performing their duties. This can be seen in the data in figure 4.5, which indicates that 33 percent of merchants felt that police were effectively enforcing the laws in 2005, 38.9 percent in 2007, and 45.4 percent in 2009. The interaction also allows for the police to enforce the laws more effectively as there may be increased cooperation between the two parties.

However, despite the perceived increases in merchants' perception of police effectiveness, it was noted that the police's ability to follow up on crimes and call responses did not improve significantly. The 2009 data results show that 42.7 percent of merchants felt that police were responding poorly or slowly to their calls for assistance. Police response was also low in 2005 and 2007 as stated by 45.9 percent and 35.7 percent of merchants, respectively. Once the BIA involvement with the foot patrol program is reduced in 2007, police response then falls back closer to the original levels before the beginning of the foot patrol program. This same trend can also be found in the data in 
regards to police following on incidents. The percentage of merchants who felt the police were doing a good job in effectively following up on crimes rose from 17.5 percent to 17.7 percent between 2005 and 2009. The 0.2 percent increase means that merchant perceptions of police follow-up have not improved in a statistically significant way. Rather, the statistical significance lies in the rise and fall of the 2005, 2007, and 2009 data results on overall police performance. 46.3 percent of merchants in 2005 felt that police where doing a poor job at following up after a report of criminal activity. This percentage then fell to 36.1 percent in 2007 , indicating that there was an improvement in perceptions of police performance in this regard. This improvement can also be seen in the merchants' 'average' response data in figure $4.5 ; 36.3$ percent in 2005 rose to 46.2 percent in 2007. In 2009, the figures reverse once again to previous levels. Where in 2007 poor response data was at 36.1 percent, the number rose to 40.6 percent in 2009 . Moreover, average response data fell from 46.2 percent in 2007 to 41.7 percent in 2009. This signifies that call response worsened as a result of the end of BIA's accountability on the foot patrol program, so did the effectiveness of police in following up on incidents. This further supports the earlier supposition that BIA involvement with the foot patrol program is important because when their involvement was removed, the perception of police was adversely affected. As the police necessity to report their dealings and provide a quality service for a paying customer -the BIA was considered a paying customer hiring 'paid duty' officers to perform duties - diminished, the police effectiveness fell as well as a result of the success of the foot patrol program in reducing levels of crime and fear. 
Measuring the Effectiveness of Foot Patrol in the Downtown Yonge BIA

Figure 4.5 - Merchant Perception of Police Performance

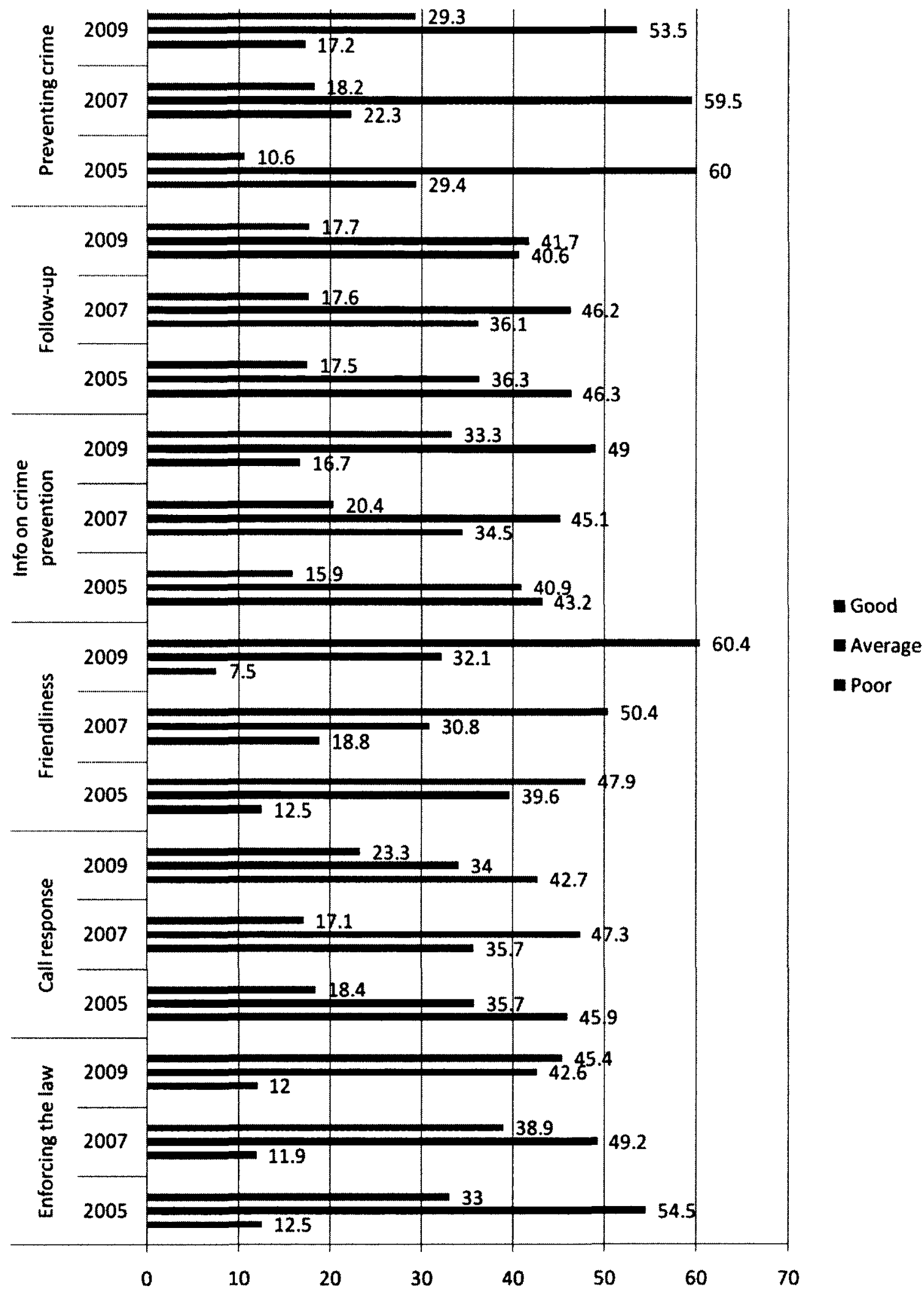


Despite the effectiveness of the foot patrol program, there are still some issues which require further attention and enforcing. In 2005 , according to figure 4.6, merchants wanted police to focus on drug users, drug dealers, and loiterers. Merchants were less concerned with panhandlers, public drunkenness, or police getting to know the merchants. Again in 2007, merchants wanted police to focus on drug users, drug dealers, and loiterers. However, greater emphasis was placed upon drug dealers and loiterers in 2007 than 2005 . The data shows that the merchants' desire to focus on drug dealers rose from 66 percent in 2005 to 76 percent in 2007 , which is a significant increase. Merchants' desire to deal with loitering also rose from 64 percent in 2005 to 69 percent in 2007 , which is a significant increase, less comparably so then drug dealers, but significant nonetheless.

Merchant focus in 2009 shifted to emphasize panhandling and public drunkenness as the greatest concerns. Panhandling rose steadily from 60 percent in 2005 to 67 percent in 2009. An increase was also reported in public drunkenness between 2005 (55 percent) and 2009 (60 percent). One explanation for the increase in the levels of panhandling and public drunkenness - which in itself may be linked but beyond the scope of this thesis is that the foot patrols were focused upon dealing with drug dealers and drug users instead of dealing with panhandlers and publicly intoxicated individuals. This supposition is supported by the perceived levels of crime and fear discussed above and the percentage of merchants identifying drug users and drug dealers as a source of problems in 2009. Drug dealers in 2007 were considered to be an issue by 76 percent of merchants but only 60 percent of merchants considered drug dealers and issue in 2009. This is a drop of 16 percent over two years, which is highly significant. This gradual 
decrease in concern is also found in the data on merchant perception of loitering in 2007 (69 percent) and 2009 (56 percent).

Figure 4.6 - Toronto Police Service Foot Patrol Focus

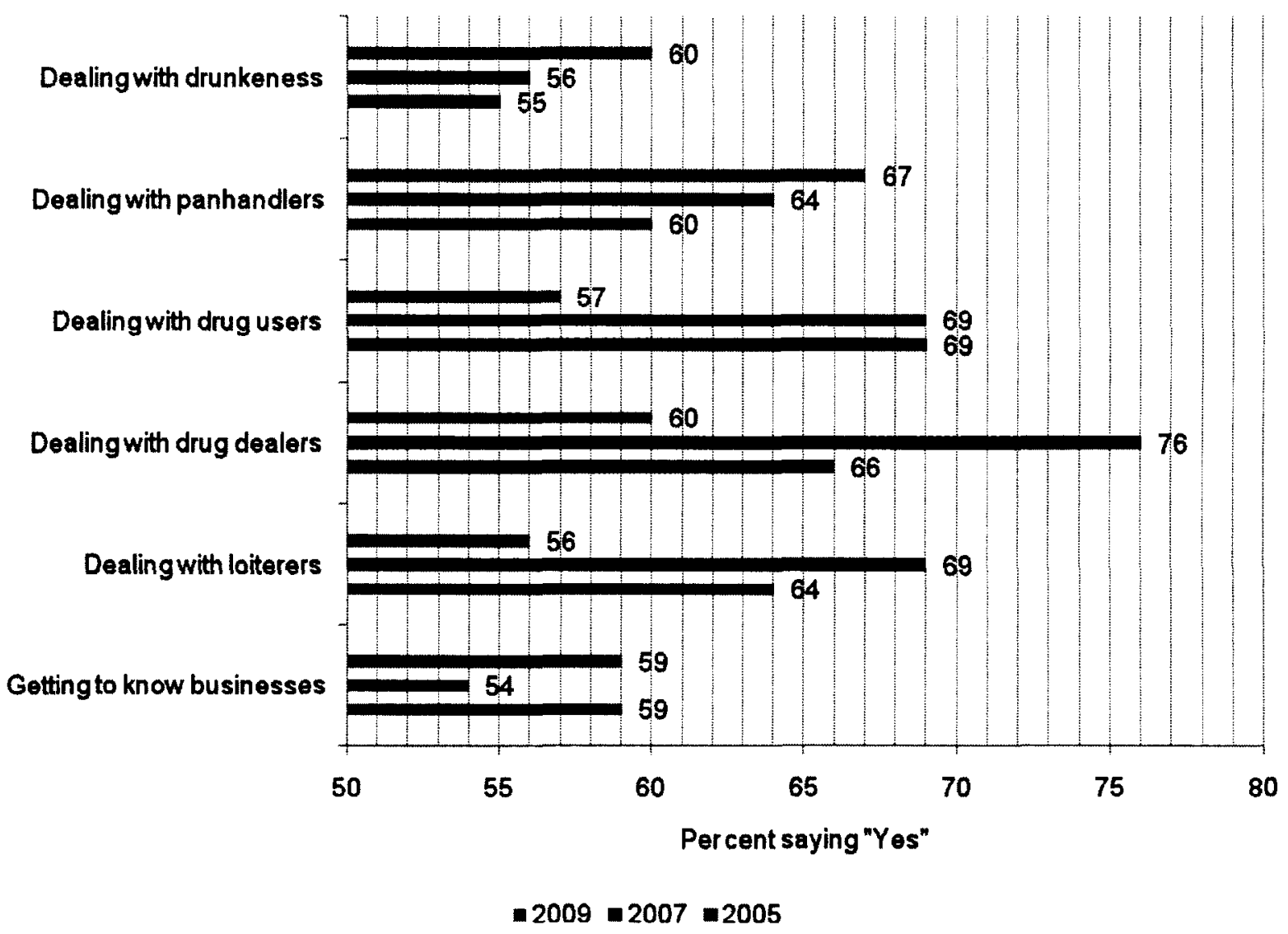

Another explanation for the data discussed throughout this chapter concerning fear, crime, and police focus lies in the frequency with which police were seen around businesses and visited businesses. As seen in figure 4.7, the figures of police visiting businesses and seen in the vicinity of businesses rose continuously from 2005 to 2009 , with the exception of police visibility in 2009, which dropped from 2007. Specifically, in 2005 police visibility was measured at an average of 3.41 times per week. This means that in a given week, the police on average were seen by merchants at least three to four days of the week; this figure rose to an average of 5.26 times per week in 2007. These 
figures show that near the end of the foot patrol program, police were seen five to six times per week walking through the area. Once the foot patrol program ended, the average perceived visibility of Police Foot Patrol lowered to 4.75 times per week in 2009 . This means that while the police were seen less often after the completion of the foot patrol program, there was no significant drop in police visitation. Moreover, the police visitation results increased continuously over all three data results. Police visits increased from 2.45 times per week on average before 2005 to 6.66 times per week on average in 2009. This means that police visitation increased steadily as a result of the foot patrol program. However, this does not explain how the figures double from 3.42 times per week in 2007 to 6.66 times per week in 2009. A possible explanation for this large increase in the rates of police visitation from 2007 to 2009 may be found in the presence of commercial shops such as Starbucks, which are geographically located in close proximity of Toronto Police 51 Division and 52 Division, and which may explain the high levels of reported visitation. That is, police were seen in the area when they went to purchase coffee, as opposed to fight crime. If the figures given for these location are on the extreme ends of the survey data, that may account for a statistically higher level of reporting. Otherwise, the data shows police visitation as a daily interaction for merchants. 


\section{Figure 4.7 - Mean TPS visits and 'seen around' merchants' place of business}

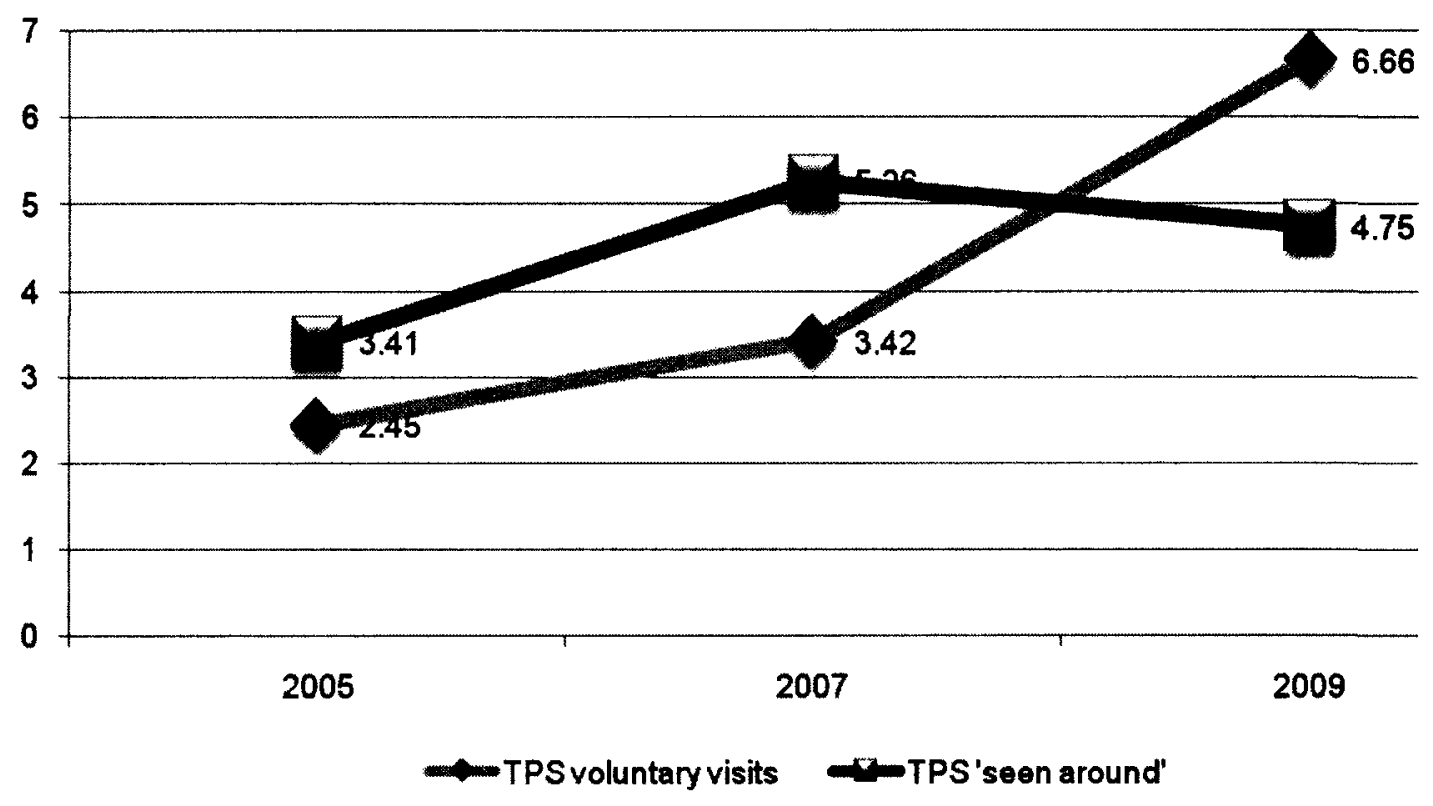

Effectiveness of Police Interaction and Visibility

The apparent effectiveness of the foot patrol program and the subsequent reaction by merchants was also measured to determine whether visitation or visibility was more effective at addressing sources of fear. Figures 4.8 to 4.15 show the comparative data from 2005 to 2009 with respect to the ten (10) variables considered to be the most significant in the study with respect to fear and risk as first discussed in chapter 3 (see Appendix $\mathrm{C}$ for more details). Police visitation and visibility were grouped in three categories: zero (0) per week; one to five (1-5) per week; and six or more (6+) per week.

The data indicates that with the exception of the fear of armed robbery, theft, serving unknown patrons after dark, fear of overall crime, and working alone after dark, the figures for 2005 and 2009 show similarities. For example, the fear of burglary in $2005\left(X^{2}=0.324, d f=2, p<.01\right)$ was measured as statistically significant. Similarly, $2009\left(\mathrm{X}^{2}=0.142, \mathrm{df}=2, \mathrm{p}<.01\right)$ was measured to be just as significant in the reduction 
of fear towards burglary. However, $2007\left(X^{2}=1.544, d f=2, p>.05\right)$ was measured as being statistically insignificant by comparison. The data for theft and the other variables shows that despite the inconsequentiality of police visitation in some areas, in other areas, police visitation was significantly effective in addressing the fear associated with a risk or crime. Police visitation was significant in reducing fear in overall crime in $2005\left(\mathrm{X}^{2}=\right.$ 17.142, df $=6, p<.01), 2007\left(X^{2}=9.201, d f=6, p<.01\right)$, and $2009\left(X^{2}=11.887, d f=\right.$ $6, \mathrm{p}<.01)$

Moreover, police visibility was shown to be effective in addressing these sources of fear, and police visitation was also revealed to be significantly involved in the reduction of fear towards crime overall in $2005\left(\mathrm{X}^{2}=4.208, \mathrm{df}=6, \mathrm{p}<.01\right), 2007\left(\mathrm{X}^{2}=\right.$ 9.774, $\mathrm{df}=6, \mathrm{p}<.05)$ and $2009\left(X^{2}=1.845, \mathrm{df}=6, \mathrm{p}<.01\right)$. Therefore, the inclusion of both foot patrol and mandatory visitation can be correlated as having significant impact upon the fear of crime and risk in the area of study.

(Figure 4.8) Overall Data - TPS Voluntarily Visited (0 Visits, 1-5 Visits, 6 or More)

\begin{tabular}{|c|c|c|c|}
\hline $\begin{array}{c}\text { Comparative } \\
\text { Variable }\end{array}$ & Year & Chi Square $\left(\mathrm{X}^{\wedge} 2\right)$ & Df \\
\hline Fear Burglary & 2005 & $0.324^{* *}$ & 2 \\
& 2007 & 1.544 & 2 \\
& 2009 & $0.142^{* * *}$ & 2 \\
\hline Fear Armed & 2005 & $0.984^{* *}$ & 2 \\
Robbery & 2007 & $1.219^{*}$ & 2 \\
& 2009 & $7.248^{*}$ & 2 \\
\hline Fear Theft & 2005 & $0.256^{*}$ & 2 \\
& 2007 & 1.597 & 2 \\
& 2009 & $6.453^{*}$ & 2 \\
\hline
\end{tabular}


(Figure 4.9) Overall Data - TPS Voluntarily Visited (0 Visits, 1-5 Visits, 6 or More)

\begin{tabular}{|c|c|c|c|}
\hline Comparative Variable & Year & Chi Square $\left(\mathrm{X}^{\wedge} 2\right)$ & Df \\
\hline Overall Crime & 2005 & $17.142^{* *}$ & 6 \\
& 2007 & $9.201^{*}$ & 6 \\
& 2009 & $11.887^{*}$ & 6 \\
\hline
\end{tabular}

(Figure 4.10) Overall Data - TPS Voluntarily Visited (0 Visits, 1-5 Visits, 6 or More)

\begin{tabular}{|c|c|c|c|}
\hline Comparative Variable & Year & Chi Square $\left(\mathrm{X}^{\wedge} 2\right)$ & Df \\
\hline Walk Alone After Dark & 2005 & $16.630^{* *}$ & $\mathbf{8}$ \\
& 2007 & 7.359 & $\mathbf{8}$ \\
& 2009 & $16.185^{*}$ & $\mathbf{8}$ \\
\hline Walk to Car After Dark & 2005 & $30.5^{* *}$ & $\mathbf{8}$ \\
& 2007 & 3.496 & $\mathbf{8}$ \\
& 2009 & $20.424^{*}$ & $\mathbf{8}$ \\
\hline Serving Unknowns after Dark & 2005 & $13.951^{* *}$ & 8 \\
& 2007 & $12.627^{*}$ & 8 \\
& 2009 & $16.551^{*}$ & $\mathbf{8}$ \\
\hline Walking Past strangers & 2005 & $19.866^{*}$ & 8 \\
& 2007 & 7.001 & 8 \\
& 2009 & $14.456^{*}$ & 8 \\
\hline Working Alone After Dark & 2005 & $13.098^{*}$ & $\mathbf{8}$ \\
& 2007 & 10.142 & 8 \\
& 2009 & $6.244^{* * *}$ & $\mathbf{8}$ \\
\hline
\end{tabular}

(Figure 4.11) Overall Data - TPS Voluntarily Visited (0 Visits, 1-5 Visits, 6 or More)

\begin{tabular}{|c|c|c|c|}
\hline Comparative Variable & Year & Chi Square ( $\left.\mathrm{X}^{\wedge} 2\right)$ & Df \\
\hline Changes in Crime 12 Months & 2005 & & \\
& 2007 & & \\
& 2009 & 9.682 & 4 \\
\hline
\end{tabular}


(Figure 4.12) Overall Data - TPS Seen Around Business (0 Times, 1-5 Times, 6 or More)

\begin{tabular}{|c|c|c|c|}
\hline Comparative Variable & Year & Chi Square $\left(\mathrm{X}^{\wedge} 2\right)$ & Df \\
\hline Walk Alone After Dark & 2005 & $9.291^{* *}$ & 8 \\
& 2007 & $8.923^{*}$ & 8 \\
& 2009 & $7.893^{* *}$ & 8 \\
\hline Walk to Car After Dark & 2005 & $8.096^{* *}$ & 8 \\
& 2007 & 10.781 & 8 \\
& 2009 & $11.319^{* *}$ & 8 \\
\hline Serving Unknowns after Dark & 2005 & $8.539^{*}$ & 8 \\
& 2007 & $8.118^{*}$ & 8 \\
& 2009 & $15.388^{* *}$ & 8 \\
\hline Walking Past strangers & 2005 & 5.019 & 8 \\
& 2007 & $10.673^{*}$ & 8 \\
& 2009 & $9.278^{* *}$ & 8 \\
\hline Working Alone After Dark & 2005 & $12.163^{* *}$ & 8 \\
& 2007 & $6.690^{*}$ & 8 \\
\hline & 2009 & $5.246^{*}$ & 8 \\
\hline
\end{tabular}

(Figure 4.13) Overall Data - TPS Seen Around Business (0 Times, 1-5 Times, 6 or More)

\begin{tabular}{|c|c|c|c|}
\hline Comparative Variable & Year & Chi Square $\left(\mathrm{X}^{\wedge} 2\right)$ & Df \\
\hline Overall Crime & 2005 & $4.208^{* *}$ & 6 \\
& 2007 & $9.774^{*}$ & 6 \\
& 2009 & $2.569^{* *}$ & 6 \\
\hline
\end{tabular}

(Figure 4.14) Overall Data - TPS Seen Around Business

(0 Times, 1-5 Times, 6 or More)

\begin{tabular}{|c|c|c|c|}
\hline Comparative Variable & Year & Chi Square $\left(\mathrm{X}^{\wedge} 2\right)$ & Df \\
\hline Fear Burglary & 2005 & $1.014^{* *}$ & 2 \\
& 2007 & $0.488^{*}$ & 2 \\
& 2009 & $0.180^{* *}$ & 2 \\
\hline Fear Armed Robbery & 2005 & $0.471^{*}$ & 2 \\
& 2007 & $0.710^{*}$ & 2 \\
& 2009 & $1.844^{* *}$ & 2 \\
\hline Fear Theft & 2005 & $1.731^{* *}$ & 2 \\
& 2007 & 0.581 & 2 \\
& 2009 & $2.394^{*}$ & 2 \\
\hline
\end{tabular}


(Figure 4.15) Overall Data - TPS Seen Around Business

(0 Times, 1-5 Times, 6 or More)

\begin{tabular}{|c|c|c|c|}
\hline Comparative Variable & Year & Chi Square $\left(\mathrm{X}^{\wedge} 2\right)$ & Df \\
\hline Changes in Crime 12 Months & 2005 & & \\
& 2007 & 3.362 & 4 \\
\hline
\end{tabular}

Personal Protection

Finally, the inclusion of personal protection in the security of a merchants' business would also have further influence upon the decreasing rates of fear of crime.

Figure 4.16 shows the change in the levels of private security from 2005 to 2009.81 .7 percent of merchants in 2005 reported that they did not use private security as a means of protecting their business. This figure decreased in 2007 to 33.1 percent and then increased again to 76.6 percent in 2009 . This would seem to indicate that the foot patrol program in 2005 reduced the role of private security as a viable means of protecting one's business according to the merchants. Once the foot patrol program ended in 2007, the promotion of private security as well as the need for private security increased. There is another possible explanation for the increase in the use of private security. This explanation involves the Boxing Day shooting of Jane Creba at Young Street and Dundas Street in 2007. A young girl was caught in a shoot out that erupted during daylight hours in Dundas Square with hundreds of people present. As a result, the merchants may have felt that their safety and their customers' perceptions of their safety, were threatened and the need for higher levels of security was necessary to reduce their levels of fear. 
Figure 4.16 - Do you employ private security?

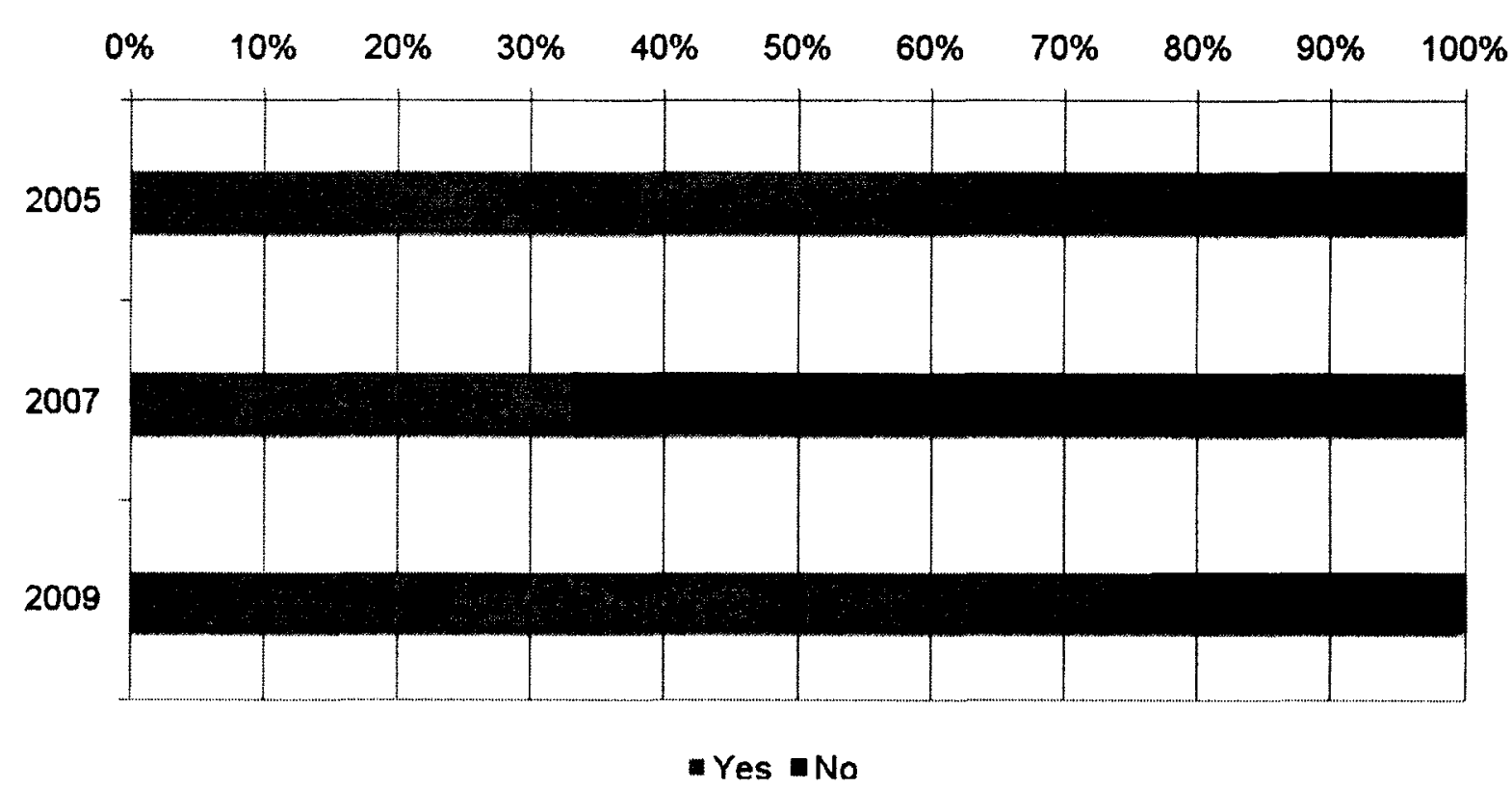

Another means of protection which has been offered to merchants is the use of Trespass to Property Act forms (TPAs) which were explained in the previous chapter. The use of trespass notices by merchants has been minimal as according to figure 4.17, which showed a change from 22.9 percent to 31.5 percent between 2005 and 2009 respectively. The reason that very few merchants utilize TPAs is because they are hard to enforce and require a great deal of cooperation by police to be effective. Merchants felt that this was not a reasonable method to address crime and manage "undesirables". This means that while merchants want police to address the sources of crime and fear, they do not wish to utilize the non-police method available to them. The previous chapter explained that merchants in 2009 did not wish to lose out on possible business by not allowing certain parties to enter their store. This reason is one of many that would explain why the merchants in all three studies reported a large majority of refusals to use TPAs. 
Measuring the Effectiveness of Foot Patrol in the Downtown Yonge BIA

Figure 4.17 - Have you completed the TPA form?

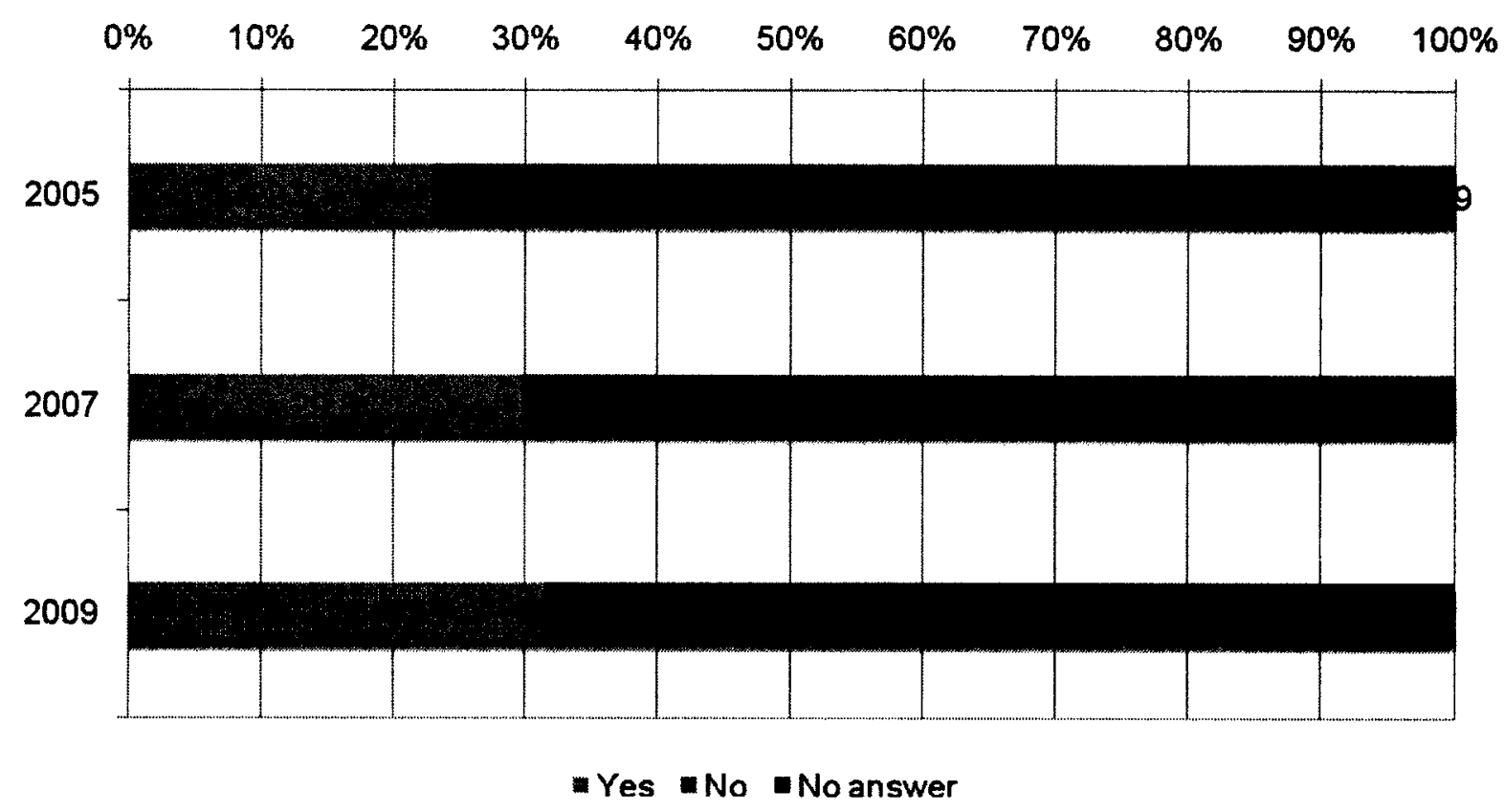




\section{Chapter 5 - In-depth Discussion}

In the previous four chapters, I have discussed the theoretical, practical, and statistical components that have developed this thesis. The purpose of this chapter is to provide a general outline of the findings and to discuss how the literature compares to the statistical results from the survey. This comparison will then be used to provide a basis for the conclusions in the next chapter. Specifically, four major areas of literature will be examined; risk \& fear, foot patrols, commodification of security, and broken windows policing.

\section{General Findings}

The general findings of this thesis are as follows:

1. The levels of crime, with the exception of theft and panhandling, in the Downtown Yonge Business Improvement Area (DYBIA) have decreased steadily since the implementation of the Foot Patrol Program.

2. The levels of fear have decreased steadily from 2005 to 2009 .

3. Perceptions of police performance have improved since the Foot Patrol Program began.

Overall, the levels of crime and fear in the Downtown Yonge Business Improvement Area have decreased since the implementation of the Foot Patrol Program. This was evident in chapters three and four as the data showed that in almost every incident discussed, merchant perception reflected that crime was not an issue. Once the foot patrol program began, crime levels and fear levels began to follow a downward trend 
which is indicative of a successful foot patrol program. However, there were other factors which influenced the success of the program, such as merchant participation, DYBIA participation and area beautification.

The increased performance of the Toronto Police may be another contributing factor in the decreased levels of fear of crime. As the Toronto Police began to focus more on the direct issues that affect a given area, the crime levels in these areas have gone down. In chapter four, one of the issues identified in 2005 was the drug trade problem. Merchants expressed their issues and concerns about the drug trade with the Toronto Police, who began to emphasize and target this behaviour.

\section{Analysis of Literature}

\section{Risk and Fear}

Chapter one outlined notions of risk and fear in society through the academic works of scholars such as Frank Furedi (2006) and Ulrich Beck (1999). Furedi (2006) described a "culture of fear" where every individual will fear for the sake of fear itself, individuals will fear something they cannot account for or identify specifically, resulting in the fear of the unknown influencing how individuals act or respond to situations. This creates a mechanism of control as it changes how a person approaches situations and how much risk they put themselves in, as noted in the earlier example where an individual came across a homeless person and reacted with fear towards them. The response to the homeless would be a result of risk management. Beck (1999) described risk management as a way to manage how much risk one assumes. The definition provided in chapter one is that risk in a "risk society" reflects the use of institutional information, both statistical 
and non-statistical, for the purpose of identifying threats, issues, and concerns that impact those institutions in order to safeguard loss or harm. Through the use of social science research, specific issues - such as problems associated with homelessness - can be targeted in order to reduce risk and fear for merchants. These methodologies attempt to reduce the impact of the culture of fear by identifying the sources of fear in a given area in order to facilitate consumption. The survey discussed in Chapter three measures the levels of fear and the perception of safety for merchants. In 2009 , the data showed that, overall, merchants did not feel that there was a safety issue pertaining to any of the nine different variables that were provided for them, with the exception of being alone in their business and travelling off of Yonge Street. However, this is different if we compare the data results for 2005 and 2009 (see figure 4.1). Chapter four identified that in 2005 and 2007 (as a result of the Jane Creba shooting), there was a high level of perceived fear associated with Yonge Street. Interestingly though, despite the high levels of perceived fear, the data comparisons showed that since 2005, the levels of perceived fear have been decreasing as a result of three contributing factors: the visibility and presence of pedestrian traffic in a busy cultural centre, DYBIA's environmental design, and the foot patrol program.

Levels of perceived fear were also elucidated in chapters three and four as merchants were asked to identify the specific crimes that caused them fear (figures 3.2 and 4.2). There were a total of 13 crimes that were identified for merchants as being possible sources of crime that would affect their business. The data results concluded that in 2005 , merchants were more concerned with issues that could directly impact their businesses as opposed to the 2009 results, which showed a focus towards community- 
based concerns. Panhandling, burglary, and loitering were three examples that were explored in chapter four as being community-based concerns. These concerns were directly related to the levels of perceived fear that merchants felt impacted them and their businesses. Panhandling was the most significant category involving feelings of fear. This thesis previously identified the homeless - panhandling which can be associated with homelessness - as a primary source of fear as it can be considered an unknown fear. How one homeless person acts versus another will change depending on the situation, but the overriding fear that is associated with the individual as the "unknown other" will be present. As a result, the data shows that the culture of fear, which Furedi identified, is still present even in areas with low levels of perceived crime.

These low levels of perceived fear were achieved through the management of risk variables such as the homeless, panhandlers, and youths within the neighbourhoods and the management of fears. Chapter one identified "undesirables" as individuals who lack the money or resources for economic exchange with business owners and cast any area where they congregate in a negative shadow. This negativity increases the levels of perceived fear for merchants and non-merchants alike and exists as the antithesis to the goals of economic and cultural centres. Some of the methods that can be utilized to minimize the risk as well as reduce the levels of perceived fear for merchants and nonmerchants include commodified security, BIAs and foot patrols.

\section{Commodified Security}

As explained in chapter one, commodified security is the market which constitutes all of the risk-preventative and fear reduction measures that the media and other agencies 
promote to manage anxiety, insecurity, and uncertainty. The data results in chapter three and four showed that the use of private security in the protection of a merchants' business was underutilized. Commodified security, which includes police foot patrols (2005 to 2007) and private security companies, are used in businesses along Yonge Street to increase protection against crime. In chapter four, figure 4.8 showed the changes in the levels of private security from 2005 to 2009 . The percentage of merchants that did not use private security fluctuated from 81.7 percent, to 33.1 percent, and then back to 76.6 percent in 2005,2007 and 2009 , respectively. This means that private security agencies - such as Intelligarde, Garda, etc. - are still not used by a large percentage of merchants. This may be attributed to merchant perceived levels of fear of crime, or simply the cost of private security (which would not be covered by DYBIA). Figure 4.3 in chapter four showed that crime in almost all areas was more of a problem in 2007. This would explain the increase in the use of private security. As a result, we can conclude that as an aid to police foot patrols, private security is effective in addressing fear of crime. Simply put, merchants feel safer if they have more protection. This is evident in the literature on risk markets as businesses promote safety through consumer products. Private security is another product on the market. Similarly, police foot patrols are also another risk/fear prevention product on the market.

\section{Foot Patrols}

In 2005, police paid duties were another product offered to manage risk and fear. Organizations, merchants, companies, and even individuals, could hire Toronto Police officers for services beyond their normal duties. The Downtown Yonge Business 
Improvement Area was one of the organizations that hired the police paid duties to patrol their area. As a result, the police managed risk and fear by achieving the five goals of foot patrol: deterrence of crime, apprehension of criminal offenders, non-crime related services, recovery of stolen goods, fortifying a sense of community security and reinforcing the confidence in the police. The data results of this thesis show that the achievement of these goals resulted in several things. First, perceptions of police performance improved steadily from 2005 to 2009 as evident by figure 4.5 . As the police were hired to specifically travel the route that the DYBIA set forth for them and the duties that were assigned to them (such as entering stores and interacting with merchants), merchant confidence rose. This is also evident in police visitation and visibility as police were becoming more visible to both merchants and criminal elements. Furthermore, police appeared to be more accountable for their actions or lack of action as a result of the requirement to report activities to the DYBIA. This in turn resulted in the targeting of issues that were deemed important by the merchants, as opposed to 2009 , where police focus is determined by the precinct.

Second, perceived levels of crime decreased once the foot patrols began. There were a few exceptions discussed in chapter three and four where certain crimes, such as panhandling, increased. However, serious incidences such as violent crime, drugs, assault, etc., decreased from 2005 to 2009 as evident by figures 4.2, 4.3, and 4.4.

Third, perceived levels of fear decreased as a result of the Foot Patrol program. The data results in figures 4.1 and 4.2 showed that perception of safety and levels of fear dropped between 2005 and 2009. This is indicative of increased safety, lower criminal activity, and fewer "undesirables". 
Finally, levels of perceived fear of crime remained low once the foot patrol was no longer privately provided. In 2007, the Downtown Yonge Foot Patrol was made a public service by Toronto Police and the DYBIA was no longer an active partner in the foot patrol program. However, despite the removal of the DYBIA oversight, the levels of fear of crime remained low. This was evident in figures 3.2 to 3.5 , and 4.1 to 4.4 in chapters 3 and 4 respectively. The chapter 3 data tables showed that in 2009, fear of crime were low. Chapter 4 data tables showed the changes as they occurred between 2005,2007 , and 2009. As was discussed in the previous chapter, fear of crime decreased between 2005 and 2007. The figures then decreased again between 2007 and 2009 which is when the police were no longer under the DYBIA umbrella.

The results of the use of foot patrol in the Downtown Yonge Business Improvement Area show that crime and fear of crime can be addressed if the goals outlined above are achieved. However, the achievement of these goals is not necessarily the only determining factor in a foot patrol program's success. There must also be the inclusion of a policing style that is aligned with the objectives of foot patrol to succeed. In this particular instance, the foot patrol program used a broken windows policing style in order to achieve the goals of the program and address fear of crime.

\section{Broken Windows Policing}

Broken Windows policing was first introduced by James Q. Wilson and George Kelling as a form of order maintenance policing. The purpose of this policing style was to minimize the fear of travelling into urban centres, reduce the risks individuals put themselves in, and remove the undesirables that contribute to risk and fear. Wilson and 
Kelling argued that there was a slippery slope effect in which one event cascades into another and so on until an area reaches a state of urban decay. As such, order maintenance was designed to target early incidents of urban decay by removing the undesirable elements before they can accumulate (Wilson \& Kelling, 1982). Police target undesirables in the area and have them removed before they cause the chain of events inherent in urban decay. The constant battle with urban decay is also coupled with the need and desire to manage the fear associated with undesirables and the risk involved in their presence for both merchants and non-merchants. In the case of the DYBIA, the targeting of undesirables as one source of urban decay was not possible. Urban decay had already begun before the initiation of the Foot Patrol program and their use of the broken windows policing style. As such, the focus of the foot patrol was to remove the undesirables that were present and reverse the urban decay. This was achieved in several ways. First, the foot patrol began to target the sources of crime that were most visible in the area such as loiterers, youth gangs, groups of teens, and individuals who were publicly intoxicated. As seen in figure 4.2 in chapter four, the levels of fear associated with these groups were very high in 2005 . This provided a starting point for the police foot patrols in addressing the undesirable population and immediate sources of fear. Furthermore, figure 4.2 showed the changes in fear associated with the targeted populations between 2005 and 2009. The data showed that with the exception of loitering, the levels of fear associated with these groups changed drastically over four years. In the first two years of the foot patrol program, there was a rise in the levels of fear associated with these undesirable groups. One of the explanations provided in chapter four was the increased notice by merchants of these groups' presence. The 
merchants previously did not account for the presence of undesirables unless they were in proximity of their business. In 2009 , when the foot patrol had effectively addressed the undesirable population within the whole of DYBIA, the merchants reported a decrease in the levels of fear associated with undesirable groups and crime.

Second, maintaining a constant police presence and visibility in the DYBIA area acts as a deterrent and reduces the opportunity for crime to occur. The Toronto Police still maintains a foot patrol program in the DYBIA that uses a broken windows style of policing in order to deal with undesirable populations. The constant presence of foot patrol officers keeps the levels of undesirables to a minimum. This results from the knowledge that if undesirables are found within the foot patrols beat, they will be asked to leave the area immediate or else be forcibly removed from the area. This maintains an atmosphere of an economic and cultural centre where the undesirable elements are removed so as to not interfere with business or safety. The removal of these elements does not mean the problem is solved but displaced as further discussed in chapter 6 .

Third, Toronto police continue to receive information and data on crime from the DYBIA and the merchants. This information and data contains a list of issues that need to be addressed by the foot patrol program as it performs its duties. The police are able to respond to the issues that they see as they are on patrol. Given that the majority of issues occur when police are not on patrol, merchants and DYBIA provide a "surveillance service" which can assist the police in addressing crime.

Finally, foot patrols working in conjunction with private security and merchants maintain the low levels of undesirables. Private security forces, such as those in the Eaton Centre, and some merchants help foot patrol programs by using the broken 
windows style of policing to remove undesirables from their property. If an undesirable is noticed on the property, they are asked to leave. If they do not comply, the police are contacted in order to have the undesirable removed from their property and from the neighbourhood. If one is noticed on another's property, the police are contacted in order to remove that individual before more undesirables come into the area. As a result, the undesirable population is managed through the cooperation of foot patrols, private police, and merchants.

The cooperation of Toronto police, private police, and merchants has resulted in a reversal of urban decay. The data results and the literature examined reach a consensus concerning the effectiveness of using broken windows policing as the main methodology in the reversal of urban decay. The original purpose of broken windows policing was to keep urban decay from developing. However, as is evident in this thesis (in conjunction with the data and literature from the previous research studies carried out), the reversal of urban decay can be achieved as well. Therefore, the research studies carried out in 2005, 2007 , and 2009 show a conclusive improvement in the levels of fear of crime within a specified area using foot patrol as the means to address crime. Moreover, the use of foot patrol, specifically a broken windows style foot patrol, is effective in decreasing the levels of fear of crime with the appropriate support. The use of foot patrol as the singular means of addressing fear of crime would not necessarily produce the same results in another area without the support from merchants, private security, and organizations such as DYBIA. 


\section{Summary}

This chapter has outlined the general findings that can be concluded from the data results in chapters 3 and 4 . The general finding included the reduction in the levels of crime and fear, and the improvement of police performance. The general findings were then used to analyze the literature discussed in chapter 1 to find correlations between the literature and the research data in order to find a relationship either supporting the use and purpose of foot patrol and broken windows policing or to explain any variances. The literature and the data concluded that the foot patrol program, originally employed by the DYBIA, was an effective program in reducing fear of crime within a specified area. The next chapter will be the penultimate conclusion to this thesis and will discuss future research possibilities. 


\section{Chapter 6-Conclusion}

This thesis has discussed that the use of foot patrol in the management and policing of undesirables through a broken windows policing style has likely assisted in reducing fear of crime in the Downtown Yonge Business Improvement Area. The broken windows policing style emphasises the removal of undesirable elements from a given area in order to reduce the negative influences upon an area. The central idea of this policing style is that if the undesirable elements are no longer present in the area then the perceived levels of fear and risk will decrease through the perceptions of safety. Through the use of research data collected in 2005, 2007, and 2009, this thesis has concluded that a foot patrol program was effective in the reducing fear of crime. However, it must be noted that this conclusion can only be applied to this particular area of study as the contributing factors - the DYBIA organization, merchant involvement, strategic lighting, streets to homes program, and other factors - are necessary in order for such a method of policing to be effective. If there are no supporting or contributing factors in the facilitation of such a policing method, this thesis cannot extend the conclusion to differing situations. In this particular situation, the use of a broken windows policing foot patrol was effective in reducing the perceived levels of crime and fear associated with "undesirables".

\section{Future Research}

Future research on the use of foot patrol as a viable method of addressing fear of crime should focus on two key areas. First, the replication of this study in another area that has similar supporting and contributing factors must be undertaken. Replication is 
necessary in order to determine whether this particular research project was successful as a result of factors not considered, and is a standalone project, or if the methodology can be used in other areas of urban decay with similar effectiveness.

Second, a foot patrol program using methods other than the broken windows policing method should be studied. This thesis focused on a broken windows policing style as its primary means of reducing fear of crime. There are other policing methods that may result in the reduction of fear of crime. These policing methods should be studied in order to find out what exactly a foot patrol requires in order to be successful. If other styles are unsuccessful, the researcher can discuss why a broken windows style was successful versus a non-broken windows style.

\section{Implications of Research}

There are several issues that arise from the research and the data that has been discussed in this thesis. The first involves the commodification of a public service. The use of Toronto Police as a commodity for safety and security raises issues concerning accountability and priorities. Public police patrols are accountable specifically to the Toronto Police Service. However, as a commodity purchased by a private organization, the question of accountability arises. If commodified police patrols are accountable to both the police service and the private organization, the private organization is allowed to influence the actions and responsibility of the foot patrols as long as they are not in conflict with the police service standards. As a result, foot patrols influenced by the private organizations may be discriminating against an undesirable population that is not actually committing crimes but will be treated as such in order to safeguard business 
interests. Moreover, police patrols begin to make note of individuals they see as undesirable and use the same methodology to remove them. The method of removal is the primary issue that surrounds such a method as broken windows as the undesirables are removed from the area but the problem is not addressed. As such, the issue of undesirables is displaced to a new area impacting the effectiveness of such a method of policing. Measuring the effectiveness of this policing method is impacted in two ways. First, effective policing cannot be measured solely based on the absence of undesirables and merchant perceptions of safety. The absence of the perceived sources of crime does not constitute a reduction in crime. Rather, the reduction of crime in one area means an increase in crime in another according to such a method of policing. As the undesirables are pushed out of one area, they naturally move to another area and continue the cycle.

Second, the measures upon which people are considered undesirable are influenced by the organization that has oversight over the foot patrol program. If the merchant organization is given oversight over the foot patrol program than the undesirables are classified as per their perception of what constitutes an "undesirable person". As such, merchant perceptions of crime are influenced by their perception. If their perception is guiding the police patrols, then there is an influence upon the levels that skew the results.

The question of priorities becomes an issue once the police patrols are influenced by private organizations. The police are charged with the equal distribution of services for all citizens and not just the "paying" ones. Police patrols that are employed by private organizations shift priorities away from equality and begin to focus on the specific pursuits that are dictated to them. As a result, there is a conflict between the 
responsibility of police patrols towards citizens and the responsibility they have to the organization that has employed them. This will need to be studied very carefully as it may have an unintended effect of privatizing policing in all urban centres.

Second, the issue of crime perhaps is not addressed by using a broken windows policing style. Crime is displaced from one area to another as they are removed from the urban centre. The displacement of crime results in crime occurring in other areas that do not have the resources that are available to economic centres such as the one studied in this thesis. Social services and other means of addressing crime should be implemented along with foot patrols in order to address crime and not just move it out of view and into other areas. If other programs are created in conjunction with foot patrols, the levels of crime may drop to the point that other areas be included in the patrol.

Third, as a result of the focus on specific areas such as the one in this thesis, police patrols are reduced in other areas creating more opportunities for crime to occur. There are a finite number of police officers that are available to patrol the entire city of Toronto. If police patrols are focusing on specified areas, other areas become vulnerable to crime (especially from the undesirables that have been removed from those areas). As a result, if police patrols focus too closely on one area or another, crime begins to increase, not decrease.

Finally, the safety and security of the officers that are patrolling in these areas should be considered more closely. As the police patrol these areas, they are exposing themselves to considerable risk to being targeted by undesirables. Police safety should be a priority when considering how to patrol a given area. This would include information on issues that have happened in the area, appropriate personal protection, readily 
available backup such as a police vehicle patrolling along with them, and the support of members of the community.

There are other benefits that have resulted from the completion and reporting of this thesis. First, the DYBIA has been provided with the information necessary to identify the issues that are occurring within their area of management. This will allow them to take further steps to ensure the safety of merchants and pedestrians that travel through their area. Second, the DYBIA is able to track the effectiveness and perceptions of police foot patrols now that they are no longer actively involved in the foot patrol program. If there is a particular issue that the police are not addressing or dealing with, the DYBIA is able to take steps in order to address those issues before they become serious problems. Third, merchants were given the opportunity to express their concerns to the DYBIA by providing feedback on the effectiveness of Toronto Police and the safety strategies employed by the DYBIA. If the merchants felt there was a particular issue that was not being addressed or they had suggestions on how to improve safety and security with the DYBIA, they were given a method of doing so. Finally, the data results that were discussed in this thesis were gathered and studied longitudinally, which provides a more accurate conclusion of the changes in fear of crime.

Public policing forces offer their services to private organizations to allow clients state-of-the-art surveillance and protection in a growing risk market. This high quality of protection creates a new tool for policing and private security that other companies are unable to provide. As such, an imbalance is created between private and public police that constantly pushes the boundaries and requires new laws and regulations to maintain those boundaries. Moreover, there is a constant need for discussion and debate 
Measuring the Effectiveness of Foot Patrol in the Downtown Yonge BIA

concerning the effectiveness of foot patrols and the services provided to deal with crime and fear, particularly, when the policing methods used concern the identification and treatment of undesirables or 'risky' populations. 


\section{Works Cited}

Archambeault, W. G. (1984). Implications of Bentham's hedonistic calculus for the study of deterrence: Marijuana use and vehicular speeding. American Journal of Police, $3(2), 229-263$.

Beck, U. (1999). World risk society. Malden: Blackwell Publishers Inc.

Bentham, J. (1995). In Bozovic M. (Ed.), The panopticon writings. London: Verso.

Bentham, J. (1970). An Introduction to the Principles of Morals and Legislation. London: The Athlone Press

Coleman, R. (2004). Reclaiming the Streets: Surveillance, Social Control, and the City. Cullompton, UK: Willan Publishing, 2004. 256pp.

Colquhoun, P. (1795). A Treatise on the Police of Metropolis, Compiled by Gulden Ozcan. London, England

Eck, J., \& Maguire, E. (2000). Have Changes in Policing Reduced Violent Crime? An Assessment of the Evidence, in Alfred Blumstein and Joel Wallman (eds) The Crime Drop in America. Cambridge, Cambridge University Press. Pp. 207-265

Ellickson, R. (1998). New Institutions for Old Neighbourhoods. Duke L. J., 48(1): 75110

Ericson, Richard V. (1982). Reproducing Order: A Study of Police Patrol Work. University of Toronto Press, Toronto.

Ericson, R. and K. Haggerty. (1997). Policing as risk communications. In Policing the Risk Society. Pp. 17-38. Toronto: University of Toronto Press.

Feeley, M., \& Simon, J. (1994) Actuarial Justice: The emerging new criminal law, in D. Nelken (ed.) The Futures of Criminology. New York: Sage.

Furedi, F. (2006). Culture of Fear Revisited; Risk-taking and the Morality of Low Expectations. Continuum, London.

Foucault, M. (1995). Discipline and punish: The birth of the prison. New York: Vintage Books.

Greene, J. (1999) Zero Tolerance: A Case Study of Police Policies and Practices in New York City. Crime and Delinquency. 45: 171-87 
Harries, Keith. (1999). Mapping Crime: Principle and Practice. http://wnw.ncirs.gov/app/publications/abstract.aspx?ID=178919. (Access October 20, 2011).

Harcourt, B. E. (1998). Reflecting on the subject: A critique of the social influence conception of deterrence, the broken windows theory, and order-maintenance policing New York style. Michigan Law Review. 97(2): 291-390

Hegel, G. W. F. (1942). Hegel's Philosophy of Right. Translated with Notes by T. M. Knox. Oxford, At the Clarendon Press, Pg 150, Article 244.

Herbert, S. (2001). Policing the Contemporary City: Fixing Broken Windows or Shoring Up Neo-liberalism?. Theoretical Criminology. 5(4): 445-466

Herbert, D., \& Norman, D. (1994). Modifying the built environment: The impact of improved street lighting. Geoforum. 25 (3): 339-50.

Hope, T., \& Hough, M. (1988). 'Area crime and incivility: A profile from the british crime survey'. In T. Hope, \& M. Shaw (Eds.), Communities and crime reduction. London: HMSO.

Hosse, H. A.; \& Przybylowski, G. A. (1976). Business Improvement Areas: Proceedings of a workshop on Downtown Improvement: Ways and Means. Toronto, Ontario, Ontario Government.

Koller, Katherine. (1990). Working the Beat; The Edmonton Neighbourhood Foot Patrol. Edmonton Police Service, Edmonton Alberta.

Lauren, P. G., Craig, G. A., \& George, A. L. (2007). Force and Statecraft; Diplomatic Challenges of Our Time $4^{\text {th }}$ ed. Oxford University Press, Oxford.

Lefebvre, H. (1996). Writings on Cities. Blackwell Publishers, Oxford.

Lefebvre, H. (2003). The Urban Revolution. University of Minnesota Press, Minneapolis.

Loukaitou-Sideris, Anastasia. (1999). Hotspots of bus stop crime: The importance of environmental attributes. Journal of the American Planning Association. 65 (4): $395-411$

Matthews, R. (1992). Replacing 'broken windows': Crime, incivilities and urban change. In Roger Matthews, Jock Young (Ed.), Issues in realist criminology (pp. 19-50). London: Sage Publications.

Neocleous, M. (2000). The Fabrication of Social Order; A Critical theory of Police Power. Pluto Press, Sterling.

Neocleous, M. (2008) Critique of Security. McGill-Queen's University Press, Kingston. 
Novak, K., Hartman, J., Holsinger, A., \& Turner, M. (1999). The Effects of Aggressive Policing of Disorder on Serious Crime. Policing: An International Journal of Police Strategies and Management. 22: 171-190

Pain, R., \& Smith, S. J. (2008). Fear: Critical geopolitics and everyday life. In Rachel Pain, \& Susan J. Smith (Eds.), Fear: Critical geopolitics and everyday life (pp. 124.). Hampshire England: Ashgate Publishing Limited.

Painter, Kate. (1996). The influence of street lighting improvements on crime, fear of crime and pedestrian street use, after dark. Landscape and Urban Planning. 35:193-201.

Police Foundation. (1981). The Newark Foot Patrol Experiment. Washington, DC.

Rigakos, George S. (2002). The New Parapolice; Risk Markets and Commodified Social Control. University of Toronto Press. Toronto.

Rose, N. (1999). Powers of Freedom; Reframing Political Thought. Cambridge University Press, Cambridge.

Rose, N. (2000). Government and Control, British Journal of Criminology, 40(2): 321-39

Sampson, R., \& Cohen, J. (1988). Deterrent Effects of the Police on Crime: A Replication and Theoretical Extension. Law \& Sociology. 163, pg 175-179.

Schell, Theodore H.; Overly, Don H.; Schack, Stephen.; Stabile, Linda L. (1976). Traditional Preventive Patrol Phase 1. National Institute of Law Enforcement and Criminal Justice. US department of Justice

Skogan, Wesley G. (1990). Disorder and decline: Crime and the spiral of decay in American neighborhoods. Los Angeles: University of California Press.

Taylor, R. (1999). Research in Brief: Crime, Grime, Fear and Decline: A Longitudinal Look. Washington, DC: National Institute of Justice

Taylor, R. (2001). Breaking Away from Broken Windows: Baltimore Neighborhoods and the Nationwide Right against Crime, Grime, Fear, and Decline. Boulder, CO: Westview Press

Vanderveen, G. (2006). Interpreting fear, crime, risk and unsafety: Conceptualisation and measurement. Den Haag: Boom Juridishe Uitgevers. 
Measuring the Effectiveness of Foot Patrol in the Downtown Yonge BIA

Appendix A 
Carleton

UNIVERSITY

Canada's Capital University

\section{Property Owner/Merchant Security Satisfaction Survey}

Contact Information:

Dr. George Rigakos (613) 520-2600 ext. 3683; Jeff Reilly

The Downtown Yonge Business Improvement Area in conjunction with Dr. George Rigakos and MA student Jeff Reilly is conducting its third biannual Policing and Security Audit. As merchants, property owners and representatives of the business community, your input is essential and your cooperation is appreciated. Please take some time to respond to the following questions. While you are under no obligation to complete every question, we would appreciate it if you would complete as many questions as you are comfortable or able to. Please be aware that this survey is ANONYMOUS and that no personal information should be included. This survey has been approved by Carleton University Research Ethics Committee, Dr. Antonio Gualtieri, Chair, phone (613) 5202517, email ethics@carleton.ca.

\section{Please Circle the Best Answer or Fill in the Blank}

1. Please tell us how many times in the last year you have been voluntarily visited by a Toronto Police Officer on foot patrol?

$$
\text { time(s) }
$$

2. How often per week do you see the Toronto Police Service on Foot in the area of your business?

/week Other

4. In the last 12 months, how would you best describe crime in the area of your business?
a. Increasing
b. Decreasing
c. About the Same

5. Would you say that crime in the area of your business overall is,
a. Very high
b. Higher than it should be
c. At a satisfactory level
d. Low 
II. How would you compare crime in the downtown Yonge area to the rest of Toronto?
a) Much higher
b) Higher
c) The same
d) Lower
e) Much lower

\section{Please Check as many as applicable}

6. On which of the following would you like to see the Toronto Police Service Foot Patrol concentrate its efforts?
a. Getting to know merchants, employees and business owners in the area
b. Dealing with loiterers
c. Dealing with drug dealers
d. Dealing with drug users
e. Dealing with panhandlers
Dealing with people drinking alcohol

f.

Please answer the following questions by circling the most reflective answer

7. Do you currently employ private security?
a. Yes
b. No

If you answered no to question 7, please skip to question 14

8. Why do you use private security?

9. How effective do you believe your private security is in relation to the Toronto Police Foot Patrol?

10. What is your annual private security budget?

$\$$ 
11. What is your annual alarm monitoring cost?

$$
\$
$$

12. What is your average annual cost associated with crime/theft?

$\$$

13. How long have you been employing private security?

a. More than 5 years

b. 3-5 years

c. 1-3 years

d. Less than a year

14. Do you think that regular visits from the Toronto Police Service Foot Patrol would be beneficial to the prevention and/or detection of crime in the area?
a. Yes
b. No
c. Not sure

15. Have you completed the Trespass to Property Act (TPA) Authorization Form which allows the Police to arrest and eject certain individuals from your Business without you having to be there?
a. Yes
b. No

16. If you did not know about this TPA form, will you fill one out now?

a. Yes

b. No

i. If no, why not?

17. What type of policing method do you most prefer?

a. Motorized (policing driving the streets and responding to incidents)

b. Foot (police walking the sidewalks and visiting merchants)

c. Bicycle

d. Mounted

e. Other, please elaborate below: 
18. For each of the following situations, please tell us if you think that the Toronto Police Service does a good job, an average job, or a poor job. Please choose the most reflective answer.
a. Enforcing the laws
b. Quickly responding to calls
c. Easy to talk to
d. Giving information to the public on ways to reduce crime
e. Following up on complaints/incidents
f. Preventing crime

$\begin{array}{cccc}\begin{array}{c}\text { Good } \\ \text { Job }\end{array} & \begin{array}{c}\text { Avera } \\ \text { ge Job }\end{array} & \begin{array}{c}\text { Poor } \\ \text { Job }\end{array} & \begin{array}{c}\text { Don't } \\ \text { Know }\end{array} \\ 0 & 0 & 0 & 0 \\ 0 & 0 & 0 & 0 \\ 0 & 0 & 0 & 0 \\ 0 & 0 & 0 & 0 \\ 0 & 0 & 0 & 0 \\ 0 & 0 & 0 & 0\end{array}$

19. Please fill in the circle that most strongly describes your feeling in the following situations within the area of your business

a. walking alone after dark

b. riding public transportation alone after dark

c. riding a bicycle alone after dark

d. walking alone to your car in a parking lot after dark

e. waiting for public transportation alone after dark

f. waiting for a friend, family member, or co-worker to drive you home after dark

g. serving customers you don't know, while alone after dark

h. walking past people you don't know, while alone after dark

i. being alone in your business after dark

\begin{tabular}{|c|c|c|c|}
\hline $\begin{array}{l}\text { Very } \\
\text { Safe }\end{array}$ & $\begin{array}{c}\text { Reasonabl } \\
\mathbf{y} \\
\text { Safe }\end{array}$ & $\begin{array}{l}\text { Neither } \\
\text { Safe nor } \\
\text { Unsafe }\end{array}$ & $\begin{array}{c}\text { Somewh } \\
\text { at } \\
\text { Unsafe }\end{array}$ \\
\hline
\end{tabular}

$0 \quad 0$

$0 \quad 0$

0

0
O

0

0

0

0

0

O

0

0

0

0

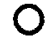

O

0

0

0

O

0

0

0

O

20. What types of criminal or other behaviour do you fear the most? Please check as many as applicable

a. Vandalism 
b. People drinking alcohol and using drugs

(e.g., marijuana, cocaine, crack, heroin) in public places

c. Groups of teenagers hanging around public places

d. Youth gangs

e. Graffiti (people writing on walls)

f. Garbage on the streets and sidewalks

g. Drug dealing

h. Armed robbery

i. Burglary

j. Violent assault

k. Panhandling

1. Loitering

m. Theft

21. Please fill in the circle that best describes any changes in these crimes over the past 12 months (since the Boxing Day shooting)

$\begin{array}{cc}\begin{array}{c}\text { More of a } \\ \text { problem }\end{array} & \begin{array}{c}\text { Less of a } \\ \text { problem }\end{array}\end{array}$

About

the same drugs (e.g., marijuana, cocaine, crack, heroin) in public places

c. Groups of teenagers hanging around public places

d. Youth gangs

e. Graffiti (people writing on walls)

f. Garbage on the streets and sidewalks

g. Drug dealing

h. Armed robbery

i. Burglary

j. Violent assault

k. Panhandling

l. Loitering

m. Theft
O

O

0

0

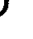

0

0

0

0

0

0

0

0

0

0

0

0
O

0

Not a problem

0

0

0

$0 \quad 0$

$0 \quad 0$

$0 \quad 0$

$0 \quad 0$

$0 \quad 0$

$0 \quad 0$

$0 \quad 0$

$0 \quad 0$

$0 \quad 0$

$0 \quad 0$

Please answer the following questions by filling in the blanks

22. What precautions does your business take after dark to help increase safety and security? 
23. Is there anything that you would like your neighbours or your community to do to make you, your business, or your customers feel safer?

24. The Toronto Police may permanently install cameras along Yonge Street. Do you believe this will make you safer? Why or why not?

$\underline{Y} / \mathrm{N}$

25. Do you believe that the installation of cameras along Yonge Street will increase the public safety? Why or why not? Y/N?

26. Are you in favour of the permanent installation of cameras on Yonge street? $\mathrm{Y} / \mathrm{N}$ Why or why not?

27. Do you have any concerned about the use of cameras? If so, what are they? 
28. Thank-you for completing this survey. We would like to remind you that everything you have told us will remain STRICTLY CONFIDENTIAL. If you would like to make some more comments, please write them in the space below.

29. Your Position/Job Title

30 (II) (Please check) are you an:

owner

non-owner

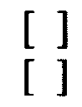

31. Sex: [ ] M [ ] F Age:

32. Block address of Store

33. Years working at your current job

34. Years working in this neighbourhood 


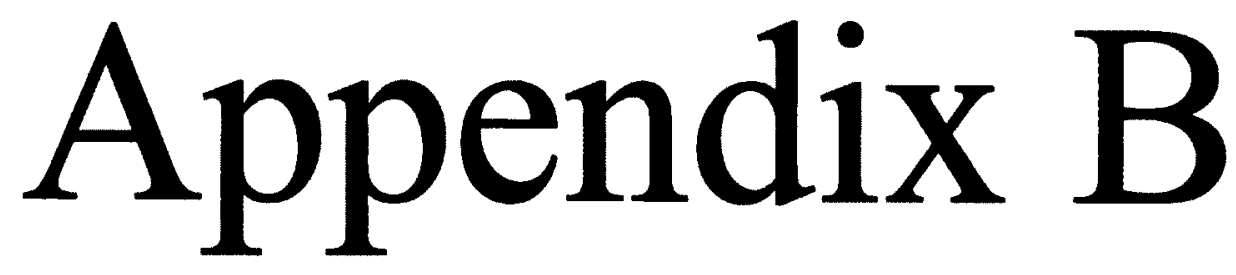



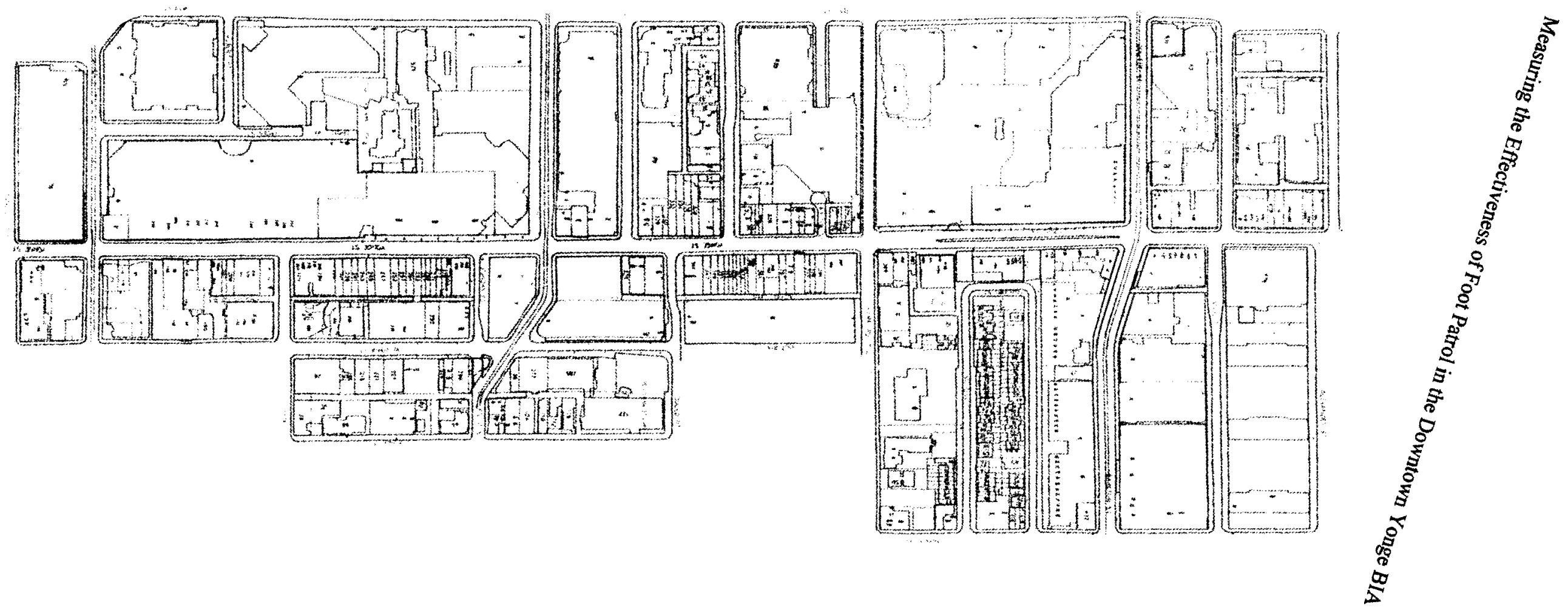
Measuring the Effectiveness of Foot Patrol in the Downtown Yonge BIA

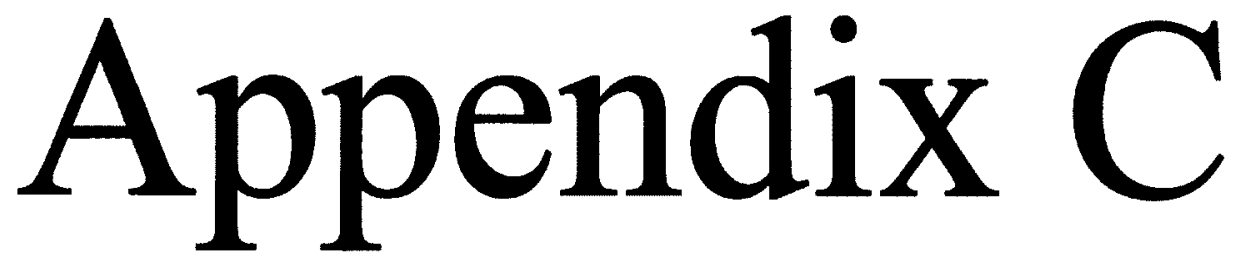


The tables presented in this chapter shows the data in chart form used to calculate statistical significance. The first section shows the percentage of tables measured in 2009. The tables following show the specific breakdowns of each individual crime for 2005,2007, and 2009. The selection choices correspond to the survey found in Appendix A.

2009 Feelings of Safety (by percentage)

\begin{tabular}{|l|r|r|r|r|r|r|r|r|r|}
\hline & Walking & Transit & Bicycle & $\begin{array}{l}\text { Parking } \\
\text { Lot }\end{array}$ & $\begin{array}{l}\text { Waiting } \\
\text { for } \\
\text { Transit }\end{array}$ & $\begin{array}{l}\text { Wait } \\
\text { for } \\
\text { Drive }\end{array}$ & $\begin{array}{l}\text { Serve } \\
\text { Customer }\end{array}$ & $\begin{array}{l}\text { Walking } \\
\text { Past }\end{array}$ & $\begin{array}{l}\text { Alone in } \\
\text { Business }\end{array}$ \\
\hline $\begin{array}{l}\text { Very } \\
\text { Unsafe }\end{array}$ & 9.9 & 3.7 & 8.5 & 19.3 & 8.5 & 7.4 & 16.7 & 12.7 & 8.1 \\
\hline $\begin{array}{l}\text { Somewhat } \\
\text { Unsafe }\end{array}$ & 12.6 & 10.1 & 13.2 & 22 & 21.7 & 18.5 & 13 & 19.1 & 22.5 \\
\hline Neither & 17.1 & 20.2 & 23.6 & 25.7 & 20.8 & 25 & 25.9 & 25.5 & 23.4 \\
\hline $\begin{array}{l}\text { Reasonably } \\
\text { Safe }\end{array}$ & 46.8 & 44 & 38.7 & 27.5 & 36.8 & 35.2 & 36.1 & 35.5 & 27 \\
\hline Very Safe & 13.5 & 22 & 16 & 5.5 & 12.3 & 13.9 & 8.3 & 7.3 & 18.9 \\
\hline
\end{tabular}

2009 Changes in Crime (by percentage)

\begin{tabular}{|c|c|c|c|c|c|c|c|c|c|c|c|c|c|}
\hline & $\begin{array}{c}\text { Vandalis } \\
\mathrm{m}\end{array}$ & $\begin{array}{c}\text { Drin } \\
\text { king' } \\
\text { Drug } \\
\text { s } \\
\end{array}$ & $\begin{array}{l}\text { Teena } \\
\text { gers }\end{array}$ & $\begin{array}{c}\text { Yout } \\
\text { h } \\
\text { Gang } \\
\text { s } \\
\end{array}$ & $\begin{array}{c}\text { Graff } \\
\text { iti }\end{array}$ & $\begin{array}{c}\text { Garba } \\
\text { ge }\end{array}$ & $\begin{array}{c}\text { Drug } \\
\text { Deali } \\
\text { ng }\end{array}$ & $\begin{array}{c}\text { Arm } \\
\text { ed } \\
\text { Robb } \\
\text { ery }\end{array}$ & $\begin{array}{l}\text { Burg } \\
\text { lary }\end{array}$ & $\begin{array}{c}\text { Violen } \\
t \\
\text { Assaul } \\
t \\
\end{array}$ & $\begin{array}{c}\text { Panhan } \\
\text { dling }\end{array}$ & $\begin{array}{l}\text { Loiteri } \\
\text { ng }\end{array}$ & Theft \\
\hline $\begin{array}{l}\text { More } \\
\text { of a } \\
\text { Proble } \\
\text { m }\end{array}$ & 14 & 24.8 & 22.9 & 21.8 & 14.8 & 31.5 & 24.8 & 8.3 & 21.8 & 19.4 & 49.1 & 31.8 & 35.2 \\
\hline $\begin{array}{l}\text { Less of } \\
\text { a } \\
\text { Proble } \\
\mathrm{m}\end{array}$ & 21.5 & 14.7 & 21.1 & 19.1 & 22.2 & 16.7 & 14.7 & 15.6 & 13.6 & 12 & 12 & 12.1 & 14.8 \\
\hline $\begin{array}{l}\text { About } \\
\text { the } \\
\text { Same }\end{array}$ & 41.1 & 42.2 & 35.8 & 30 & 35.2 & 34.3 & 41.3 & 31.2 & 30 & 37 & 28.7 & 43 & 35.2 \\
\hline $\begin{array}{l}\text { Not a } \\
\text { Proble } \\
\mathrm{m} \\
\end{array}$ & 18.7 & 13.8 & 17.4 & 26.4 & 24.1 & 13.9 & 15.6 & 42.2 & 31.8 & 27.8 & 6.5 & 9.3 & 10.2 \\
\hline $\begin{array}{l}\text { Not } \\
\text { Applic } \\
\text { able }\end{array}$ & 4.7 & 4.6 & 2.8 & 2.7 & 3.7 & 3.7 & 3.7 & 2.8 & 2.7 & 3.7 & 3.7 & 3.7 & 4.6 \\
\hline
\end{tabular}

Fear of Crime (by percentage)

\begin{tabular}{|l|r|r|r|l|l|l|l|l|l|l|l|l|l|}
\hline & $\begin{array}{l}\text { Vandal } \\
\text { ism }\end{array}$ & $\begin{array}{l}\text { Drink } \\
\text { ing/D } \\
\text { rugs }\end{array}$ & $\begin{array}{l}\text { Teen } \\
\text { agers }\end{array}$ & $\begin{array}{l}\text { h } \\
\text { Gang } \\
\mathrm{s}\end{array}$ & $\begin{array}{l}\text { Graffi } \\
\mathrm{ti}\end{array}$ & $\begin{array}{l}\text { Garb } \\
\text { age }\end{array}$ & $\begin{array}{l}\text { Drug } \\
\text { Deali } \\
\mathrm{ng}\end{array}$ & $\begin{array}{l}\text { Arme } \\
\mathrm{R} \\
\text { Robb } \\
\text { ery }\end{array}$ & $\begin{array}{l}\text { Burgl } \\
\text { ary }\end{array}$ & $\begin{array}{l}\text { Viole } \\
\text { Ast } \\
\text { Assa }\end{array}$ & $\begin{array}{l}\text { Panh } \\
\text { andli } \\
\text { ng }\end{array}$ & $\begin{array}{l}\text { Loite } \\
\text { ring }\end{array}$ & Theft \\
\hline & & & & & & & & & & & & & \\
No & 55 & 44.1 & 67.6 & 52.3 & 70.3 & 68.5 & 48.6 & 56.8 & 42.3 & 45.9 & 43.2 & 49.5 & 24.3 \\
\hline & & & & & & & & & & & & & \\
Yes & 45 & 55.9 & 32.4 & 47.7 & 29.7 & 31.5 & 51.4 & 43.2 & 57.7 & 54.1 & 56.8 & 50.5 & 75.7 \\
\hline
\end{tabular}




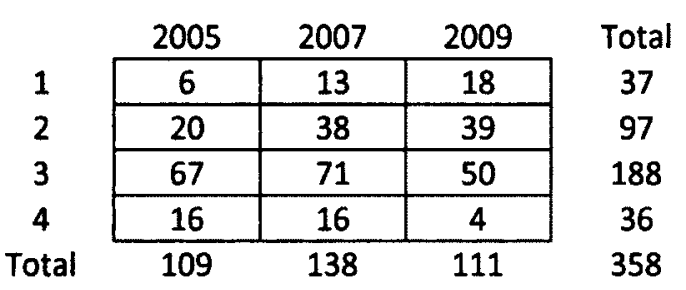

\begin{tabular}{|c|c|c|c|c|}
\hline & 2005 & 2007 & 2009 & Total \\
\hline 1 & 39 & 43 & 49 & 131 \\
\hline 2 & 70 & 97 & 62 & 229 \\
\hline Total & 109 & 140 & 111 & 360 \\
\hline
\end{tabular}

\begin{tabular}{|c|c|c|c|c|}
\hline & 2005 & 2007 & 2009 & Total \\
\hline 1 & 37 & 34 & 44 & 115 \\
\hline 2 & 72 & 105 & 67 & 244 \\
\hline Total & 109 & 139 & 111 & 359 \\
\hline
\end{tabular}

\begin{tabular}{|c|c|c|c|c|}
\hline & 2005 & 2007 & 2009 & Total \\
\hline 1 & 34 & 43 & 48 & 125 \\
\hline 2 & 75 & 97 & 63 & 235 \\
\hline Total & 109 & 140 & 111 & 360 \\
\hline
\end{tabular}

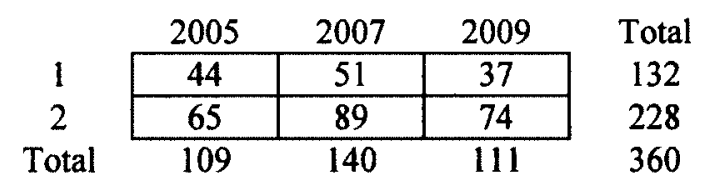

\begin{tabular}{|c|c|c|c|c|}
\hline & 2005 & 2007 & 2009 & Total \\
\hline 1 & 49 & 62 & 44 & 155 \\
\hline 2 & 60 & 78 & 67 & 205 \\
\hline Total & 109 & 140 & 111 & 360 \\
\hline
\end{tabular}

Crimeall

\begin{tabular}{l|c|c|c|c}
\multicolumn{1}{c}{2005} & 2007 & 2009 & \multirow{2}{*}{ Total } \\
1 & 0.06 & 0.09 & 0.16 & 0.311411 \\
2 & 0.18 & 0.28 & 0.35 & 0.8102 \\
3 & 0.61 & 0.51 & 0.45 & 1.579622 \\
\cline { 2 - 4 } & 0.15 & 0.12 & 0.04 & 0.298767 \\
\cline { 2 - 4 } & 1 & 1 & 1 & 3
\end{tabular}

Noloiter

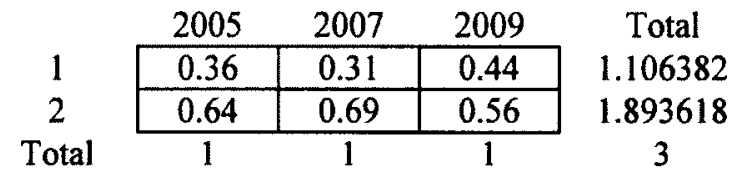

Dealers

\begin{tabular}{|c|c|c|c|c|}
\hline & 2005 & 2007 & 2009 & Total \\
\hline 1 & 0.34 & 0.24 & 0.40 & 0.98045 \\
\hline 2 & 0.66 & 0.76 & 0.60 & 2.01955 \\
\hline Total & 1 & 1 & 1 & 3 \\
\hline
\end{tabular}

users

\begin{tabular}{|c|c|c|c|c|}
\hline & 2005 & 2007 & 2009 & Total \\
\hline 1 & 0.31 & 0.31 & 0.43 & 1.051502 \\
\hline 2 & 0.69 & 0.69 & 0.57 & 1.948498 \\
\hline & 1 & 1 & 1 & 3 \\
\hline
\end{tabular}

Panhandle

\begin{tabular}{l|c|c|c|c} 
& 2005 & 2007 & 2009 & Total \\
\cline { 2 - 4 } 2 & 0.40 & 0.36 & 0.33 & 1.101289 \\
& 0.60 & 0.64 & 0.67 & 1.898711 \\
\cline { 2 - 4 } & 1 & 1 & 1 & 3
\end{tabular}

Drinkers

\begin{tabular}{c|c|c|c|c}
2005 & 2007 & 2009 & Total \\
\cline { 2 - 4 } 2 & 0.45 & 0.44 & 0.40 & 1.288795 \\
\hline 0.55 & 0.56 & 0.60 & 1.711205 \\
\hline 1 & 1 & 1 & 3
\end{tabular}

wlkalone

\begin{tabular}{c|c|c|c|c}
\multicolumn{1}{c}{2005} & 2007 & 2009 & Total \\
-2 & 0.14 & 0.11 & 0.10 & 0.34 \\
-1 & 0.30 & 0.21 & 0.13 & 0.64 \\
0 & 0.14 & 0.13 & 0.17 & 0.44 \\
1 & 0.38 & 0.47 & 0.47 \\
\cline { 1 - 3 } 2 & 0.05 & 0.09 & 0.14 & 0.31 \\
\cline { 2 - 4 } & 0.27 \\
\cline { 2 - 4 } & 1 & 1 & 1 & 3
\end{tabular}

ttcalone

\begin{tabular}{|c|c|c|c|}
\hline & 2005 & 2007 & 2009 \\
\hline-2 & 0.09 & 0.07 & 0.04 \\
\hline 1 & 0.16 & 0.16 & 0.10 \\
\hline
\end{tabular}




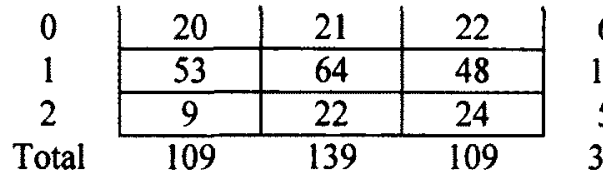

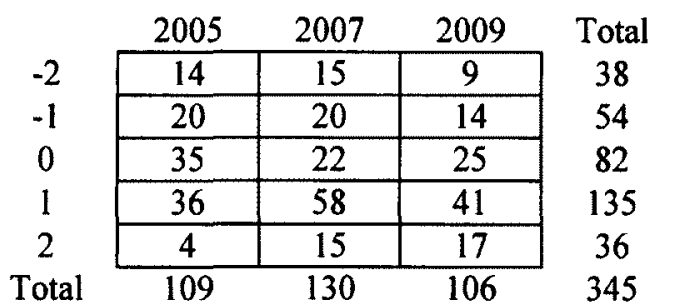

\begin{tabular}{|c|c|c|c|}
\hline & 2005 & 2007 & 2009 \\
\hline-2 & 20 & 18 & 21 \\
\hline-1 & 26 & 40 & 24 \\
\hline 0 & 33 & 21 & 28 \\
\hline 1 & 28 & 47 & 30 \\
\hline 2 & 2 & 9 & 6 \\
\hline Total & 109 & 135 & 109 \\
\hline
\end{tabular}

63
165
55
357

345

Total

59

90

82

105

353

\begin{tabular}{|c|c|c|}
\hline \multicolumn{1}{c}{2005} & 2007 & 2009 \\
\hline 13 & 14 & 9 \\
\hline 34 & 35 & 23 \\
\hline 27 & 17 & 22 \\
\hline 31 & 53 & 39 \\
\hline 4 & 19 & 13 \\
\hline 109 & 138 & 106 \\
\hline
\end{tabular}

Total

36

92

66

123

36

353

\begin{tabular}{|c|c|c|c|}
\hline & 2005 & 2007 & 2009 \\
\hline-2 & 5 & 14 & 8 \\
\hline-1 & 27 & 22 & 20 \\
\hline 0 & 32 & 27 & 27 \\
\hline 1 & 40 & 54 & 38 \\
\hline 2 & 5 & 19 & 15 \\
\hline Total & 109 & 136 & 108 \\
\hline
\end{tabular}

Total

27

69

86

132

39

353

\begin{tabular}{|c|c|c|c|}
\hline & 2005 & 2007 & 2009 \\
\hline-2 & 20 & 15 & 18 \\
\hline-1 & 23 & 34 & 14 \\
\hline 0 & 35 & 32 & 28 \\
\hline 1 & 24 & 41 & 39 \\
\hline 2 & 7 & 14 & 9 \\
\hline Total & 109 & 136 & 108 \\
\hline
\end{tabular}

Total

53

71

95

104

30

353

\begin{tabular}{|c|c|c|c|}
\hline & 2005 & 2007 & 2009 \\
\hline-2 & 11 & 13 & 14 \\
\hline-1 & 33 & 37 & 21 \\
\hline 0 & 33 & 28 & 28 \\
\hline 1 & 29 & 49 & 39 \\
\hline 2 & 3 & 13 & 8 \\
\hline
\end{tabular}

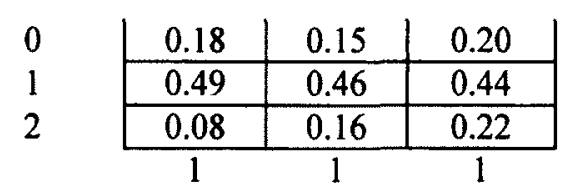

0.54

1.39

0.46

3

bicalone

\begin{tabular}{c|c|c|c|c|}
\multicolumn{1}{c}{2005} & 2007 & 2009 & Total \\
-2 & 0.13 & 0.12 & 0.08 & 0.33 \\
-1 & 0.18 & 0.15 & 0.13 \\
0 & 0.32 & 0.17 & 0.24 \\
0.47 \\
1 \\
\cline { 2 - 4 } 2 & 0.33 & 0.45 & 0.39 \\
\cline { 2 - 4 } & 0.04 & 0.12 & 0.16 \\
1.16 \\
0.31 \\
\cline { 2 - 3 } & 1 & 1 & 1 & 3
\end{tabular}

walkplot

\begin{tabular}{c|c|c|c|}
\multicolumn{1}{c}{2005} & 2007 & 2009 \\
-2 & 0.19 & 0.13 & 0.19 \\
\hline-1 & 0.22 & 0.30 & 0.22 \\
\hline 0 & 0.26 & 0.16 & 0.26 \\
\hline 1 & 0.28 & 0.35 & 0.28 \\
\hline 2 & 0.06 & 0.07 & 0.06 \\
\hline
\end{tabular}

Total

0.52

0.74

0.67

0.90

0.18

3

ttcwait

\begin{tabular}{c|c|c|c|}
\multicolumn{1}{c}{2005} & 2007 & 2009 & Total \\
-2 & 0.12 & 0.10 & 0.08 \\
-1 & 0.31 & 0.25 & 0.22 \\
0 & 0.25 & 0.12 & 0.21 \\
0.78 \\
1 \\
\cline { 2 - 4 } 2 & 0.28 & 0.38 & 0.37 \\
\hline 0.04 & 0.14 & 0.12 \\
0.58 \\
1.04 \\
0.30 \\
\cline { 2 - 4 } \\
\cline { 2 - 4 } & 1 & 1 & 3
\end{tabular}

frndwait

\begin{tabular}{|c|c|c|c|c|}
\hline & 2005 & 2007 & 2009 & Total \\
\hline-2 & 0.05 & 0.10 & 0.07 & 0.22 \\
\hline-1 & 0.25 & 0.16 & 0.19 & 0.59 \\
\hline 0 & 0.29 & 0.20 & 0.25 & 0.74 \\
\hline 1 & 0.37 & 0.40 & 0.35 & 1.12 \\
\hline 2 & 0.05 & 0.14 & 0.14 & 0.32 \\
\hline & 1 & 1 & 1 & 3 \\
\hline
\end{tabular}

helpcust

\begin{tabular}{c|c|c|c|}
\multicolumn{1}{c}{2005} & 2007 & 2009 \\
\hline-2 & 0.18 & 0.11 & 0.17 \\
\hline-1 & 0.21 & 0.25 & 0.13 \\
\hline 0 & 0.32 & 0.24 & 0.26 \\
\hline 1 & 0.22 & 0.30 & 0.36 \\
\hline 2 & 0.06 & 0.10 & 0.08 \\
\hline 1
\end{tabular}

Total

0.46

0.59

0.82

0.88

0.25

wlkpeople

Total
38
91
89
117
24

\begin{tabular}{|c|c|c|}
\multicolumn{1}{c}{2005} & \multicolumn{1}{c}{2007} & 2009 \\
\hline 0.10 & 0.09 & 0.13 \\
\hline 0.30 & 0.26 & 0.19 \\
\hline 0.30 & 0.20 & 0.25 \\
\hline 0.27 & 0.35 & 0.35 \\
\hline 0.03 & 0.09 & 0.07 \\
\hline
\end{tabular}

Total

0.32

0.76

0.76

0.97

0.19 
Measuring the Effectiveness of Foot Patrol in the Downtown Yonge BIA

$\begin{array}{lllll}\text { Total } & 109 & 140 & 110 & 359\end{array}$

\begin{tabular}{|c|c|c|c|}
\hline & 2005 & 2007 & 2009 \\
\hline-2 & 19 & 20 & 9 \\
\hline-1 & 25 & 32 & 25 \\
\hline 0 & 27 & 22 & 26 \\
\hline 1 & 31 & 45 & 30 \\
\hline 2 & 7 & 19 & 21 \\
\hline Total & 109 & 138 & 111 \\
\hline
\end{tabular}

Total
48
82
75
106
47
358

\begin{tabular}{|c|c|c|c|}
\hline & 2005 & 2007 & 2009 \\
\hline 1 & 66 & 63 & 61 \\
\hline 2 & 43 & 70 & 50 \\
\hline Total & 109 & 133 & 111 \\
\hline
\end{tabular}

Total

190

163

353

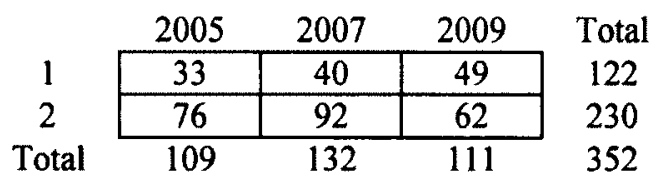

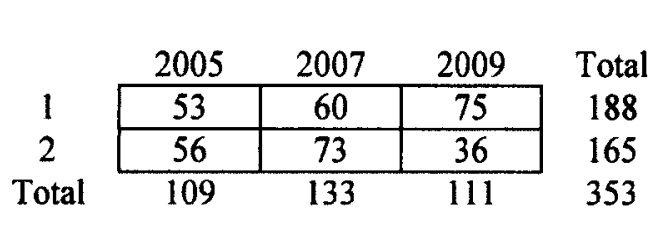

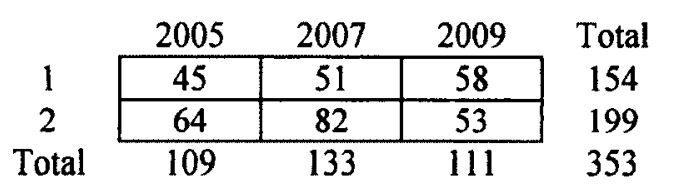

workalone

\begin{tabular}{|c|c|c|c|c|}
\hline 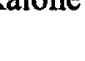 & 2005 & 2007 & 2009 & Total \\
\hline-2 & 0.17 & 0.14 & 0.08 & 0.40 \\
\hline-1 & 0.23 & 0.23 & 0.23 & 0.69 \\
\hline 0 & 0.25 & 0.16 & 0.23 & 0.64 \\
\hline 1 & 0.28 & 0.33 & 0.27 & 0.88 \\
\hline 2 & 0.06 & 0.14 & 0.19 & 0.39 \\
\hline & 1 & 1 & 1 & 3 \\
\hline
\end{tabular}

fearvand

\begin{tabular}{|c|c|c|c|c|}
\hline & 2005 & 2007 & 2009 & Total \\
\hline 1 & 0.61 & 0.47 & 0.55 & 1.628738 \\
\hline 2 & 0.39 & 0.53 & 0.45 & 1.371262 \\
\hline & 1 & 1 & 1 & 3 \\
\hline
\end{tabular}

feardrug

\begin{tabular}{|c|c|c|c|c|}
\hline & 2005 & 2007 & 2009 & Total \\
\hline 1 & 0.30 & 0.30 & 0.44 & 1.047224 \\
\hline 2 & 0.70 & 0.70 & 0.56 & 1.952776 \\
\hline & 1 & 1 & 1 & 3 \\
\hline
\end{tabular}

fearteen

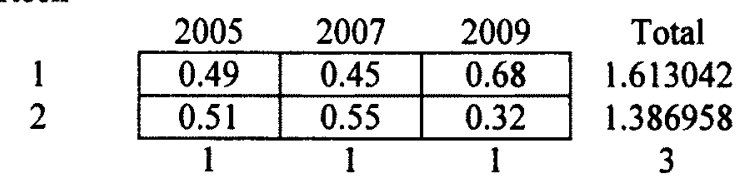

feargang

\begin{tabular}{|c|c|c|c|c|}
\hline & 2005 & 2007 & 2009 & Total \\
\hline 1 & 0.41 & 0.38 & 0.52 & 1.318825 \\
\hline 2 & 0.59 & 0.62 & 0.48 & 1.681175 \\
\hline & 1 & 1 & 1 & 3 \\
\hline
\end{tabular}

feargraf

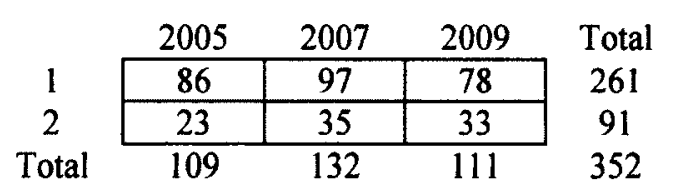

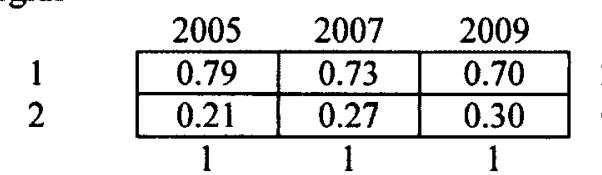

Total

2.226542 0.773458

3

feargarb

\begin{tabular}{|c|c|c|c|c|}
\hline \multirow{3}{*}{$\begin{array}{l}1 \\
2\end{array}$} & 2005 & 2007 & 2009 & Total \\
\hline & 79 & $\overline{90}$ & 76 & 245 \\
\hline & 30 & 42 & 35 & 107 \\
\hline Total & 109 & 132 & 111 & 352 \\
\hline
\end{tabular}

\begin{tabular}{l|c|c|c|}
\multicolumn{1}{c}{2005} & 2007 & 2009 \\
\hline & 0.72 & 0.68 & 0.68 \\
\hline 0.28 & 0.32 & 0.32 \\
\hline & 1 & 1 & 1
\end{tabular}

Total

2.091274 0.908726

3

feardeal

\begin{tabular}{|c|c|c|c|c|}
\hline & 2005 & 2007 & 2009 & Total \\
\hline 1 & 44 & 38 & 54 & 136 \\
\hline 2 & 65 & 95 & 57 & 217 \\
\hline Total & 109 & 133 & 111 & 353 \\
\hline
\end{tabular}

\begin{tabular}{|c|c|c|c|c|}
\hline & 2005 & 2007 & 2009 & Total \\
\hline 1 & 28 & 33 & 63 & 124 \\
\hline 2 & 81 & 100 & 48 & 229 \\
\hline Total & 109 & 133 & 111 & 353 \\
\hline
\end{tabular}
$20052007 \quad 2009 \quad$ Total

Total

1.17587

1.82413

3

fearrobbery

\begin{tabular}{lc|c|c|}
\multicolumn{2}{|c}{2005} & 2007 & 2009 \\
\hline 0.26 & 0.25 & 0.57 \\
\hline 0.74 & 0.75 & 0.43 \\
\hline 1 & 1 & 1 & 1
\end{tabular}

Total

1.072569

1.927431

3

fearburglary 
Measuring the Effectiveness of Foot Patrol in the Downtown Yonge BIA

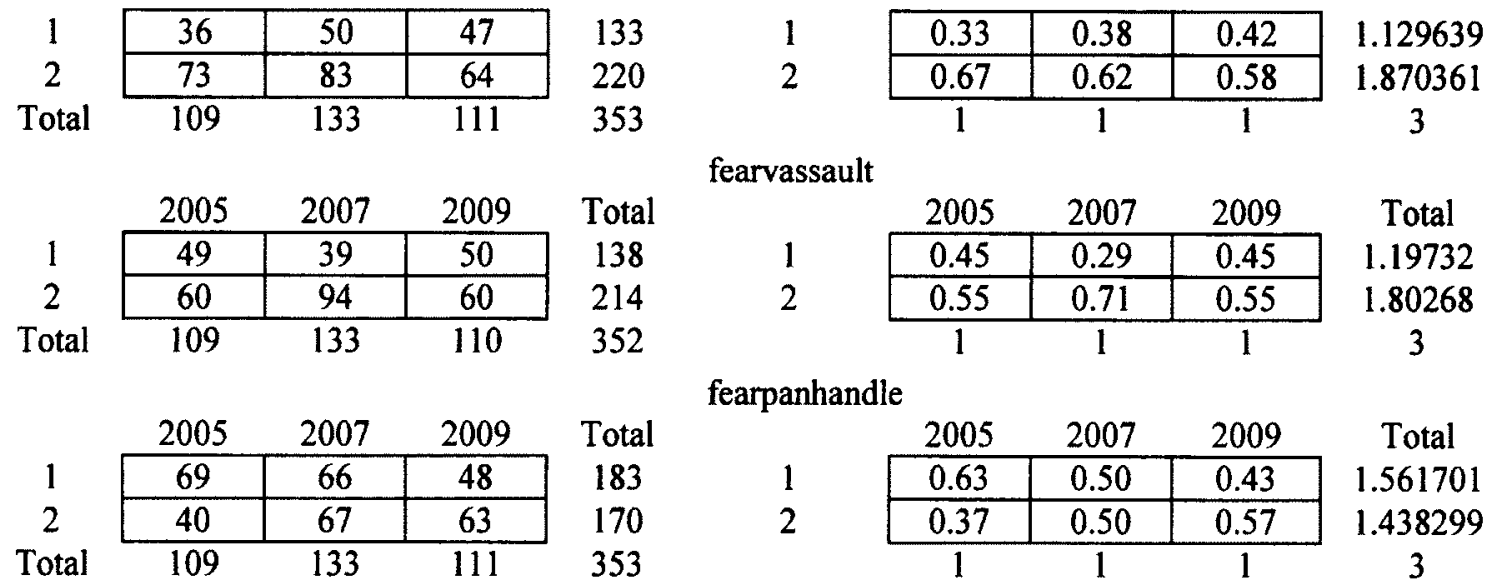

\begin{tabular}{|c|c|c|c|c|}
\hline & 2005 & 2007 & 2009 & Total \\
\hline 1 & 33 & 68 & 55 & 156 \\
\hline 2 & 76 & 65 & 56 & 197 \\
\hline Total & 109 & 133 & 111 & 353 \\
\hline
\end{tabular}

fearloiter

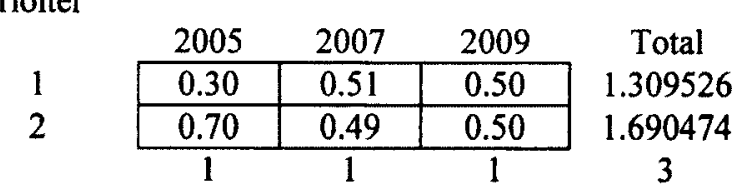

\begin{tabular}{|c|c|c|c|c|}
\hline & 2005 & 2007 & 2009 & Total \\
\hline 1 & 60 & $\overline{25}$ & 27 & 112 \\
\hline 2 & 49 & 108 & 84 & 24 \\
\hline Total & 109 & 133 & 111 & 353 \\
\hline
\end{tabular}

feartheft

\begin{tabular}{|c|c|c|c|}
\hline 2005 & 2007 & 2009 & Total \\
\hline 0.55 & 0.19 & 0.24 & 0.981672 \\
\hline 0.45 & 0.81 & 0.76 & 2.018328 \\
\hline 1 & 1 & 1 & 3 \\
\hline
\end{tabular}

\begin{tabular}{|c|c|c|c|}
\hline & & NTRFO & \\
\hline & 2005 & 2007 & 2009 \\
\hline varo & 2 & 54 & 44 \\
\hline var1-7 & 87 & 68 & 45 \\
\hline $\operatorname{var} 7<$ & 20 & 7 & 20 \\
\hline total & 109 & 129 & 109 \\
\hline
\end{tabular}

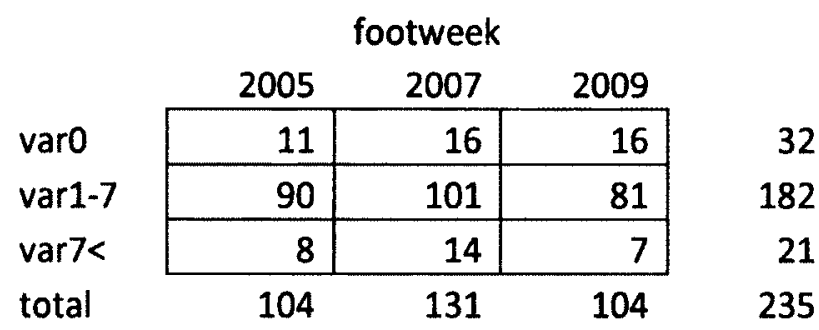

